\title{
User's Guide to the North Pacific Pelagic Seabird Database 2.0
}
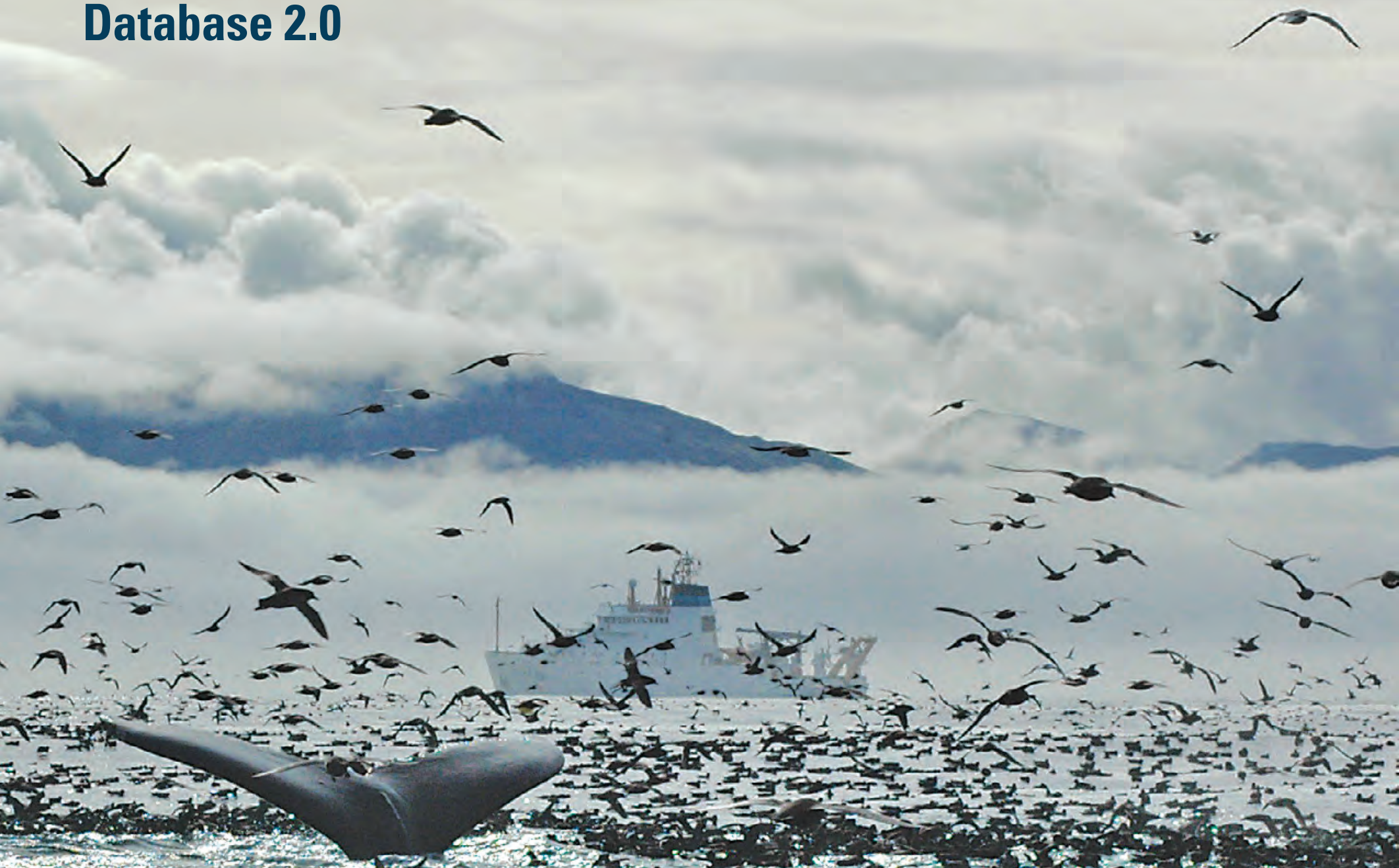

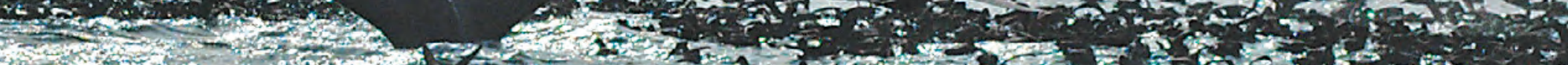

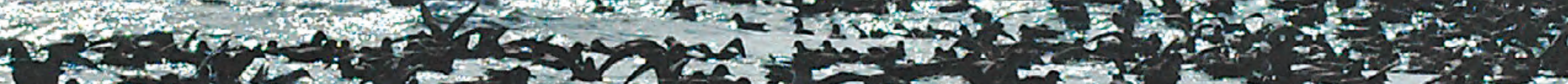

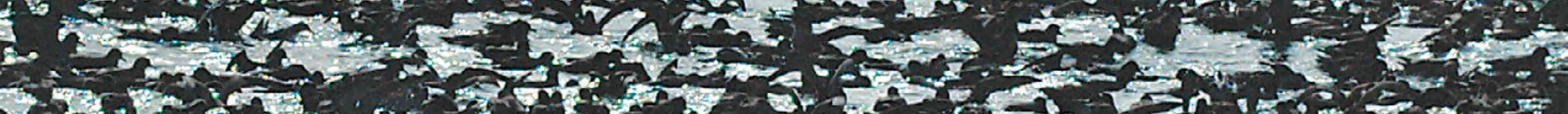

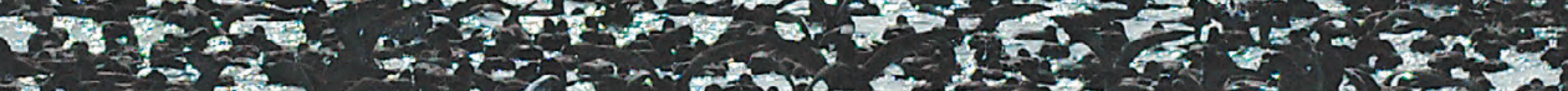

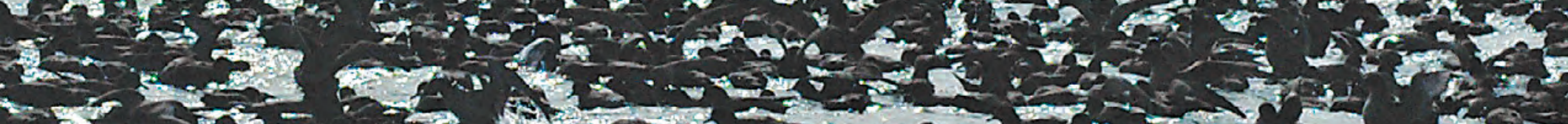

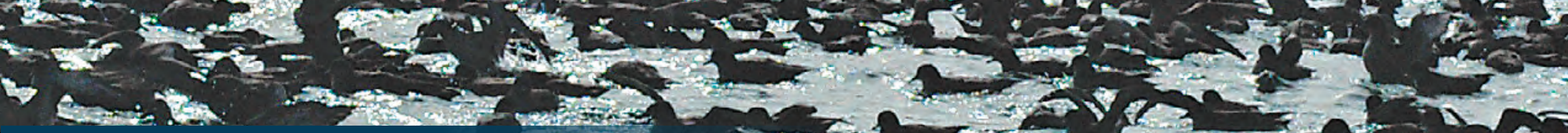

Open-File Report 2015-1123
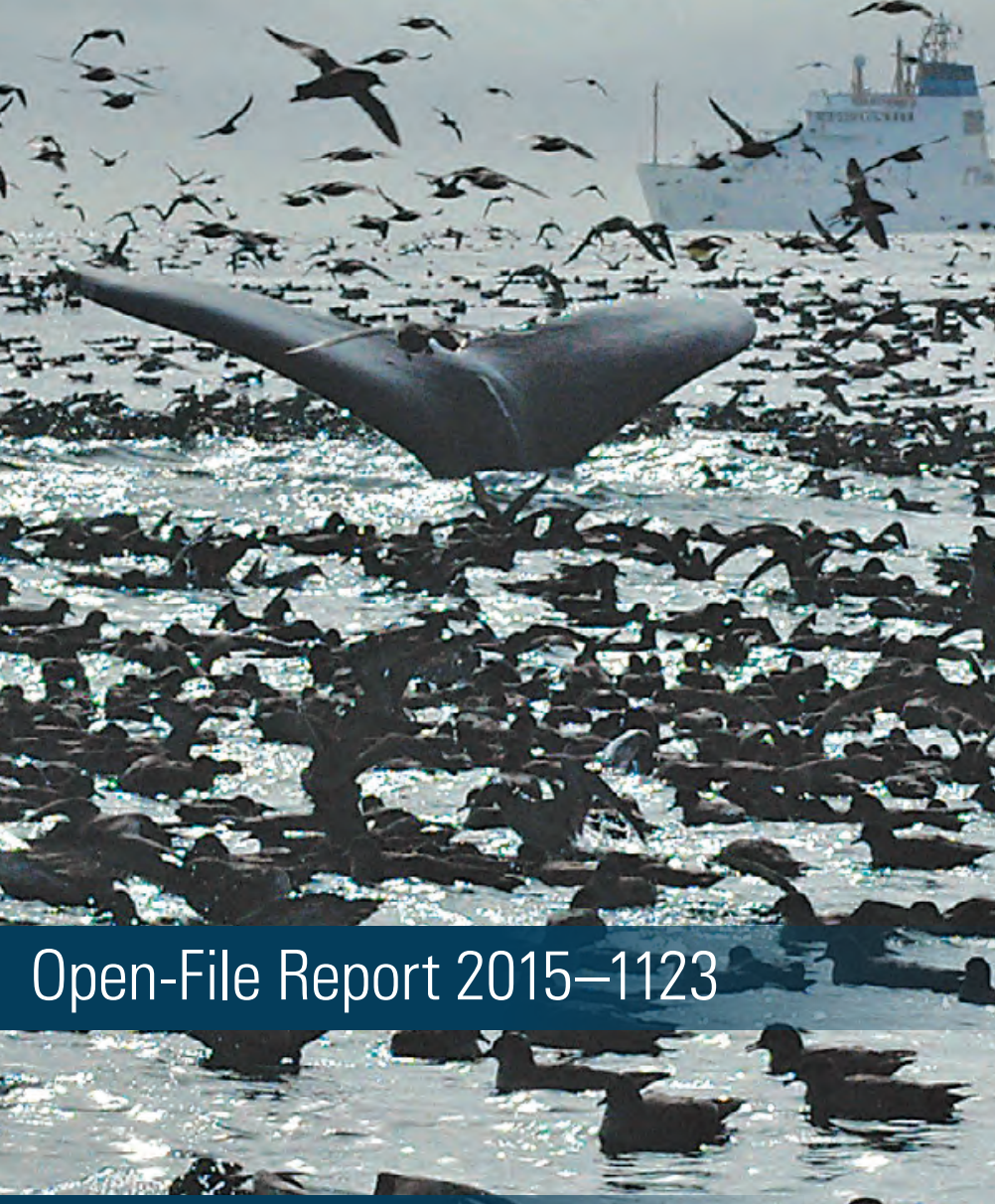

U.S. Department of the Interior

U.S. Geological Survey

$\rightarrow \Rightarrow$ कas 
Cover: A large flock of short-tailed shearwaters is joined by a humpback whale at feeding grounds in the eastern Aleutian Islands, Alaska. Typical of large vessels used to collect data on seabirds and marine mammals in the North Pacific, the NOAA ship Oscar Dyson is passing in the background. Photograph by Phil Clapham, National Oceanic and Atmospheric Administration (NOAA), September 7, 2005. 


\section{User's Guide to the North Pacific Pelagic Seabird Database 2.0}

By Gary S. Drew, John F. Piatt, and Martin Renner

Open-File Report 2015-1123

U.S. Department of the Interior

U.S. Geological Survey 


\section{U.S. Department of the Interior \\ SALLY JEWELL, Secretary}

\section{U.S. Geological Survey \\ Suzette M. Kimball, Acting Director}

U.S. Geological Survey, Reston, Virginia: 2015

For more information on the USGS-the Federal source for science about the Earth,

its natural and living resources, natural hazards, and the environment-visit

http://www.usgs.gov or call 1-888-ASK-USGS (1-888-275-8747)

For an overview of USGS information products, including maps, imagery, and publications, visit http://www.usgs.gov/pubprod

To order this and other USGS information products, visit http://store.usgs.gov

Any use of trade, firm, or product names is for descriptive purposes only and does not imply endorsement by the U.S. Government.

Although this information product, for the most part, is in the public domain, it also may contain copyrighted materials as noted in the text. Permission to reproduce copyrighted items must be secured from the copyright owner.

Suggested citation:

Drew, G.S., Piatt, J.F., and Renner, M., 2015, User's guide to the North Pacific Pelagic Seabird Database 2.0: U.S. Geological Survey Open-File Report 2015-1123, 52 p., http://dx.doi.org/10.3133/ofr20151123.

ISSN 2331-1258 (online) 


\section{Contents}

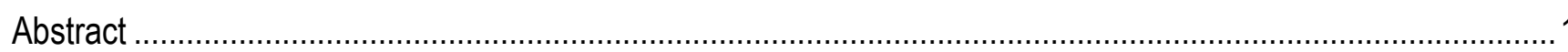

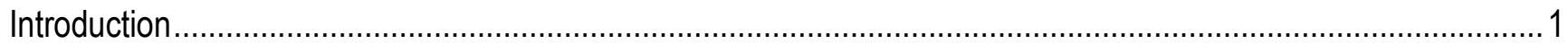

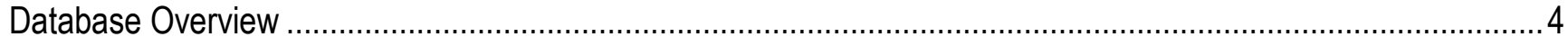

Data Sources and Geographic Coverage ………….........................................................................

Database Structure …………….................................................................................................

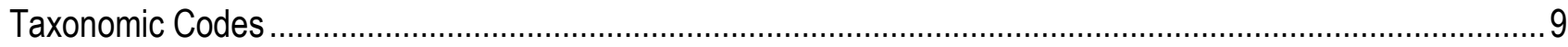

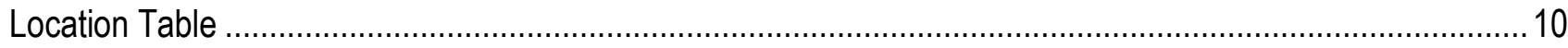

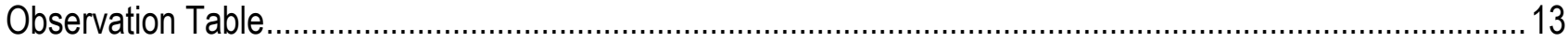

Metadata for Contributed Surveys ....................................................................................................... 14

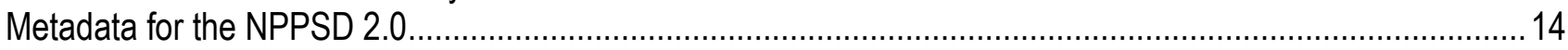



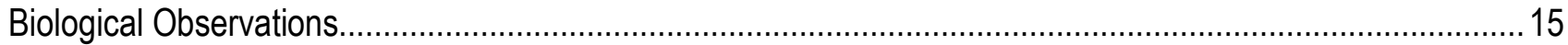

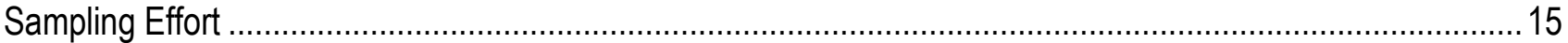

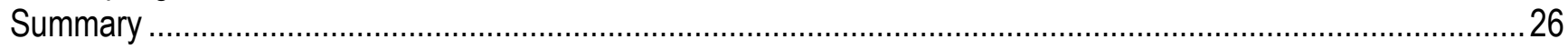

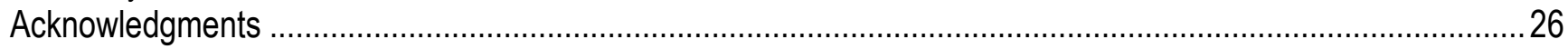

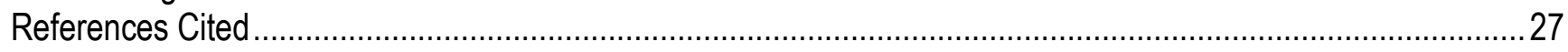

Appendix A. List of Contributors to the North Pacific Pelagic Seabird Database as Individuals,

Program Managers, or Institutions ...............................................................................................

Appendix B. Map Showing Geographic Regions Used for Table 1............................................................ 32

Appendix C. Bird Species from the North Pacific Pelagic Seabird Database (NPPSD) Taxonomic

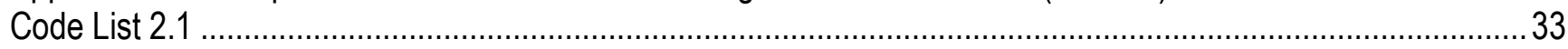

Appendix D. Marine Mammal Species from the North Pacific Pelagic Seabird Database (NPPSD) Taxonomic

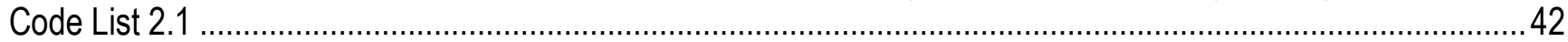

Appendix E. North Pacific Pelagic Seabird Database, Version 2 Query Tool ...................................................... 44

\section{Figures}

Figure 1. Global map showing scale of the North Pacific Pelagic Seabird Database (NPPSD) ........................... 5

Figure 2. Geographic coverage of the North Pacific Pelagic Seabird Database (NPPSD) ………........................ 6

Figure 3. Conceptual model of North Pacific Pelagic Seabird Database processing and structure ....................... 8

Figure 4. Density of Tufted Puffin across the North Pacific, 1973-2012 …................................................. 18

Figure 5. Distribution of samples (number of $\mathrm{km}^{2}$ surveyed) in the North Pacific Pelagic Seabird Database

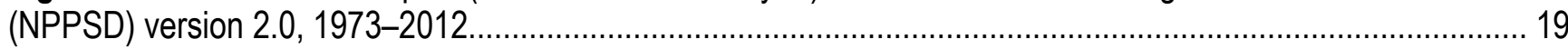

Figure 6. Sum of area sampled (number of $\mathrm{km}^{2}$ surveyed) during four time periods $(A)$ 1973-1982, (B) 1983-

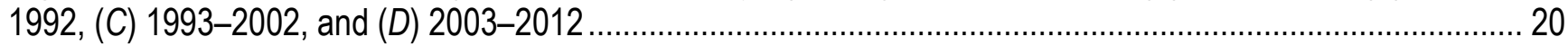

Figure 7. North Pacific Pelagic Seabird Database (NPPSD) version 2.0 sample representation across four decades-1973-1982, 1983-1992, 1993-2002, and 2003-2012...

Figure 8. Numbers of monthly samples and sampled area for the North Pacific Pelagic Seabird Database (NPPSD), 1973-2012.

Figure 9. Graph showing numbers of monthly samples and sampled area for the North Pacific Pelagic Seabird Database (NPPSD), 1973-2012 


\section{Tables}

Table 1. Spatial distribution of pelagic seabird survey data (effort and observations) in the North Pacific Pelagic Seabird Database 2.0

Table 2. Fields and data descriptions of the location table ("tbl_Location") of the North Pacific Pelagic

Seabird Database

Table 3. Fields and descriptions of the observation table ("tbl_Data_Obs") of the North Pacific Pelagic

Seabird Database 14

Table 4. A listing of the 20 most abundant bird taxa in the North Pacific Pelagic Seabird Database 2.0 16

Table 5. A listing of the 20 most abundant marine mammal species in the North Pacific Pelagic Seabird Database 2.0

\section{Conversion Factors, Datum, and Abbreviations and Acronyms}

\section{Conversion Factors}

SI to Inch/Pound

\begin{tabular}{lcl}
\hline \multicolumn{1}{c}{ Multiply } & \multicolumn{1}{c}{ Ly } & \multicolumn{1}{c}{ To obtain } \\
\hline meter $(\mathrm{m})$ & 3.281 & foot $(\mathrm{ft})$ \\
kilometer $(\mathrm{km})$ & 0.6214 & mile $(\mathrm{mi})$ \\
meter $(\mathrm{m})$ & 1.094 & yard $(\mathrm{yd})$ \\
\hline \multicolumn{3}{c}{ Area } \\
\hline square kilometer $\left(\mathrm{km}^{2}\right)$ & 247.1 & acre \\
square kilometer $\left(\mathrm{km}^{2}\right)$ & 0.3861 & square mile $\left(\mathrm{mi}^{2}\right)$ \\
\hline & Vessel speed & \\
\hline kilometer per hour $(\mathrm{km} / \mathrm{h})$ & 0.6214 & mile per hour $(\mathrm{mi} / \mathrm{h})$ \\
\hline
\end{tabular}

Temperature in degrees Celsius $\left({ }^{\circ} \mathrm{C}\right)$ may be converted to degrees Fahrenheit $\left({ }^{\circ} \mathrm{F}\right)$ as follows:

${ }^{\circ} \mathrm{F}=\left(1.8 \times{ }^{\circ} \mathrm{C}\right)+32$

\section{Datum}

Horizontal coordinate information is referenced to the World Geodetic System 1984 (WGS84) datum.

\section{Abbreviations and Acronyms}

FGDC Federal Geographic Data Committee

GIS geographic information system

GPS Global Positioning System

NOAA National Oceanic and Atmospheric Administration

NODC National Oceanographic Data Center

NPPSD North Pacific Pelagic Seabird Database

OCSEAP Outer Continental Shelf Environmental Assessment Program

PICES North Pacific Marine Science Organization

USGS U.S. Geological Survey 


\title{
User's Guide to the North Pacific Pelagic Seabird Database 2.0
}

\author{
By Gary S. Drew, John F. Piatt, and Martin Renner
}

\begin{abstract}
The North Pacific Pelagic Seabird Database (NPPSD) was created in 2005 to consolidate data on the oceanic distribution of marine bird species in the North Pacific. Most of these data were collected on surveys by counting species within defined areas and at known locations (that is, on strip transects). The NPPSD also contains observations of other bird species and marine mammals. The original NPPSD combined data from 465 surveys conducted between 1973 and 2002, primarily in waters adjacent to Alaska. These surveys included 61,195 sample transects with location, environment, and metadata information, and the data were organized in a flat-file format. In developing NPPSD 2.0, our goals were to add new datasets, to make significant improvements to database functionality and to provide the database online. NPPSD 2.0 includes data from a broader geographic range within the North Pacific, including new observations made offshore of the Russian Federation, Japan, Korea, British Columbia (Canada), Oregon, and California. These data were imported into a relational database, proofed, and structured in a common format. NPPSD 2.0 contains 351,674 samples (transects) collected between 1973 and 2012, representing a total sampled area of 270,259 square kilometers, and extends the time series of samples in some areas - notably the Bering Sea - to four decades. It contains observations of 16,988,138 birds and 235,545 marine mammals and is available on the NPPSD Web site. Supplementary materials include an updated set of standardized taxonomic codes, reference maps that show the spatial and temporal distribution of the survey efforts and a downloadable query tool.
\end{abstract}

\section{Introduction}

The North Pacific is a vast region with complex topography and numerous oceanographic ecoregions that support a large number of highly productive marine communities, including globally significant fisheries and populations of seabirds and marine mammals. Seabirds are ubiquitous members of these communities and as higher trophic level consumers, they integrate processes that reflect primary and secondary production in marine ecosystems (Diamond and Devlin, 2003). Additionally, seabirds are relatively easy to observe and monitor, and all these qualities make seabirds useful indicators of marine ecosystem status (Veit and others, 1996; Piatt and others, 2007; Bond and others, 2011). 
Data on the pelagic distribution and abundance of seabirds are critical for understanding the basic ecology of marine birds, monitoring population trends, assessing the effects of human activities, identifying critical marine habitats, and educating the public about seabird conservation. Specifically, at-sea surveys in the North Pacific have been used to:

- Assess the impacts of oil spills on marine bird populations (Ford and others, 1987; Piatt and others, 1990; Burger, 1992; Klosiewski and Laing, 1994);

- Assess long-term changes in marine ecosystems in response to climate or geological changes (Ainley and others, 1995; Veit and others, 1996; Agler and others, 1999; Drew and others, 2010; Renner and others, 2013);

- Identify scaled features of marine ecosystems (Piatt and others, 1991; Elphick and Hunt, 1993; Piatt and Springer, 2004, 2007);

- Measure association of seabirds with biophysical features and identify structure in marine communities (Gould and Piatt, 1993; Springer and others, 1999; Piatt and others, 2006; Drew and others, 2012; Renner and others, 2012);

- Estimate population sizes of rare or threatened species that are impossible to census using traditional methods (Piatt and Ford, 1993; Agler and others, 1998; Piatt and others, 2007, 2011);

- Examine seasonal movements and winter habitat use by seabirds (Piatt and Naslund, 1995; Agler and others, 1998, Renner and others, 2008);

- Assess conflicts between commercial fisheries and marine birds (Karpouzi and others, 2007; Renner and others, 2013); and

- Plan marine reserves and bird protected areas (Hyrenbach and others, 2006; Smith and others, 2014).

Most of these projects have focused on addressing fine- to meso-scale ecological questions, and few have been conducted over a sufficiently large spatial area or long enough timeframe to draw conclusions about broad-scale processes - for example, decadal-scale changes in large marine ecosystems (Renner and others, 2013). This limitation largely has been a logistical one. With few exceptions, the cost (in terms of money and the time required to conduct at-sea surveys) has restricted the scope of marine bird studies to relatively small $\left(<10,000 \mathrm{~km}^{2}\right)$ marine areas, and has limited the ability to investigate processes that operate at large spatial scales.

The solution to high logistical costs is to combine the various directed and opportunistic surveys for marine birds at sea conducted during recent decades by different organizations and researchers. The need for a comprehensive geographic database on the pelagic distribution of seabirds in the North Pacific has long been recognized. During the Outer Continental Shelf Environmental Assessment Program (OCSEAP), administered by the National Oceanographic and Atmospheric Administration (NOAA), millions of dollars were provided from 1973 through 1982 to conduct at-sea surveys of biological resources in advance of oil development on the Alaska Outer Continental shelf. This work culminated in an atlas on the "Pelagic Distribution and Abundance of Seabirds in the Gulf of Alaska and Eastern Bering Sea" (Gould and others, 1982), which documented the at-sea distribution and abundance of 16 common seabird species in Alaska. The end of OCSEAP funding signaled the end of at-sea survey data consolidation in the North Pacific until the U.S. Geological Survey initiated efforts to compile the pelagic seabird data again during the 1990s (Piatt, 1992; Piatt and Ford, 2001). 
With support from the North Pacific Research Board in 2002, we constructed the NPPSD 1.0, assembling datasets collected since 1982 and then integrating the datasets with the OCSEAP data. NPPSD 1.0 included data from 465 individual surveys conducted between 1974 and 2002 consisting of 61,195 transects (samples) with counts of 6,995,932 birds and 29,739 marine mammals. Most at-sea seabird surveys usually have included collection of data on marine mammals because they are often observed foraging in the same areas as marine birds (Croll and others, 1998). A large number of marine mammals were observed outside the boundaries of strip transects for birds, so the data cannot be used to calculate densities, but all observations were included in the database because of their use in determining general distributions or ranges. NPPSD 1.0 has been used frequently for analyses of seabird and marine mammal distribution in the North Pacific (for example, Piatt and Springer, 2004, 2007; Hunt and others, 2005; Drew and Piatt, 2008; Piatt and others, 2006, 2007; Melvin and others, 2006; Renner and others, 2008).

In developing NPPSD 2.0, we expanded the geographic scope of the database to include the important marine areas adjacent to the large marine ecosystems of Alaska (Gulf of Alaska, eastern Bering Sea, and Chukchi and Beaufort Seas) and that share common avifauna, including areas such as the California Current (from Canada to southern California), the western Bering Sea, and the Sea of Okhotsk. We also included more associated environmental data. The overarching goal of the NPPSD project continues to be the compilation of North Pacific seabird surveys to provide a tool for addressing broad-scale ecological questions. The proliferation of large spatial-scale environmental datasets derived from satellite imagery (for example, sea-surface temperature, chlorophyll-a) now provides an opportunity to measure habitat associations over expanded spatial and temporal scales. Additionally, making the NPPSD 2.0 accessible from the USGS Alaska Science Center Website (alaska.usgs.gov) expands public access to results of federally funded research.

The specific objectives for the NPPSD 2.0 were to:

- Compile, document, and archive new incoming datasets.

- Develop and maintain a current taxonomic code list.

- Standardize formats and reorganize individual raw datasets into two tables: locations and observations.

- Merge all individual datasets into the NPPSD 2.0 database using the two-table structure.

- Release database on USGS Alaska Science Center Website.

- Create and collaborate on products developed from the data.

- Promote the development of a "community of practice" for users of the NPPSD 2.0 to facilitate broad-scale spatial and long-term temporal analyses.

In this report, we provide details regarding how we designed the database, the database sources, spatial and temporal coverage, structure, and data use. In addition to the database itself, two additional tools have been developed-(1) an updated taxonomic code list, and (2) a data extraction interface. Both of these tools can be accessed through the USGS Alaska Science Center Website. 


\section{Database Overview}

\section{Data Sources and Geographic Coverage}

The NPPSD 2.0 contains marine bird survey data that span the North Pacific, bounded by the United States and Canada on the east, and the Russian Federation, Japan and Korea on the west (fig. 1). Sampling longitudes range from $129^{\circ} \mathrm{E}$ to $117^{\circ} \mathrm{W}$. Sampling latitudes range from $88.5^{\circ} \mathrm{N}$ to the equator, but samples south of latitude $30^{\circ} \mathrm{N}$ are very limited. The largest survey efforts occurred on the continental shelves of Alaska, British Columbia and California. The NPPSD 1.0 included all OCSEAP at-sea seabird surveys as well as additional survey data from Southeast Alaska, Prince William Sound, Cook Inlet, Aleutian Islands, and eastern Bering Sea (Drew and Piatt 2005). New datasets were acquired for the coasts and shelves of California, Oregon, Washington, British Columbia, western Bering Sea, and the Sea of Okhotsk (fig. 2). NPPSD 2.0 extends not just the spatial coverage, but also the temporal range of observations to 1973-2012. In some areas, these new data provided the first repeated sampling in 30 years. The effects of the additional data went beyond extending the temporal range. For example, the first version of the database had no data from the Sea of Okhotsk, but in the NPPSD 2.0, data were added from that region for a period spanning 22 years (1984-2005).

The new survey datasets were collected by numerous Federal, State, and foreign agencies working on various projects. The list of contributors is provided in appendix A. The diversity of contributors introduced various raw dataset formats, and datasets often lacked metadata documentation. We archived all incoming datasets and associated metadata, if provided. Most of the surveys included in the NPPSD 2.0 collected data on multiple species; however, there are a small number of taxa specific surveys where only one or two species were recorded. Users should note this distinction when selecting data. The geographic distribution of sampling effort is detailed in table 1 . These areas are based on a modified version of the North Pacific Marine Science Organization (PICES) subregion map (appendix B). 


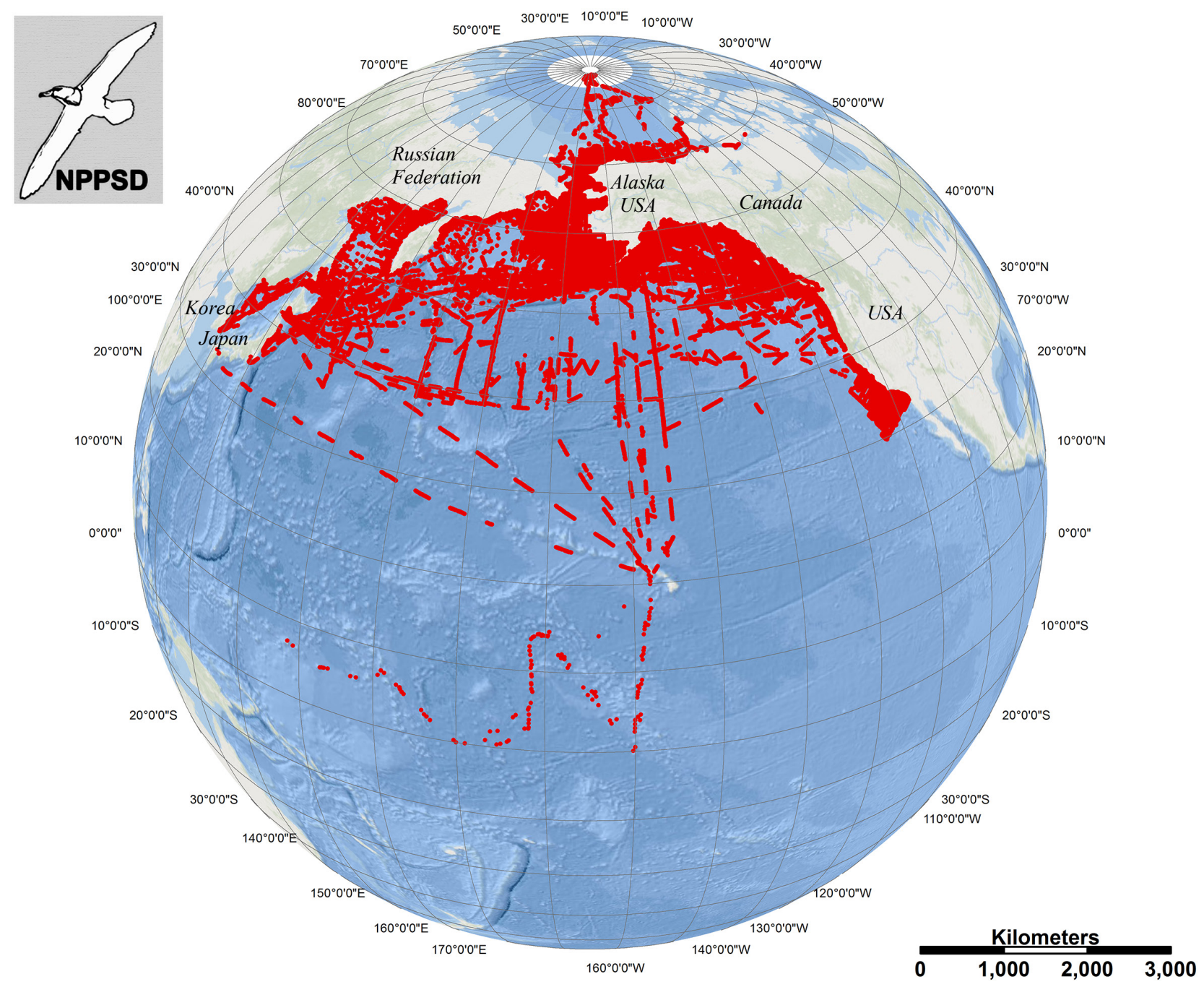

Figure 1. Global map showing scale of the North Pacific Pelagic Seabird Database (NPPSD). Red dots are individual transects (samples; total of 351,674 ). 


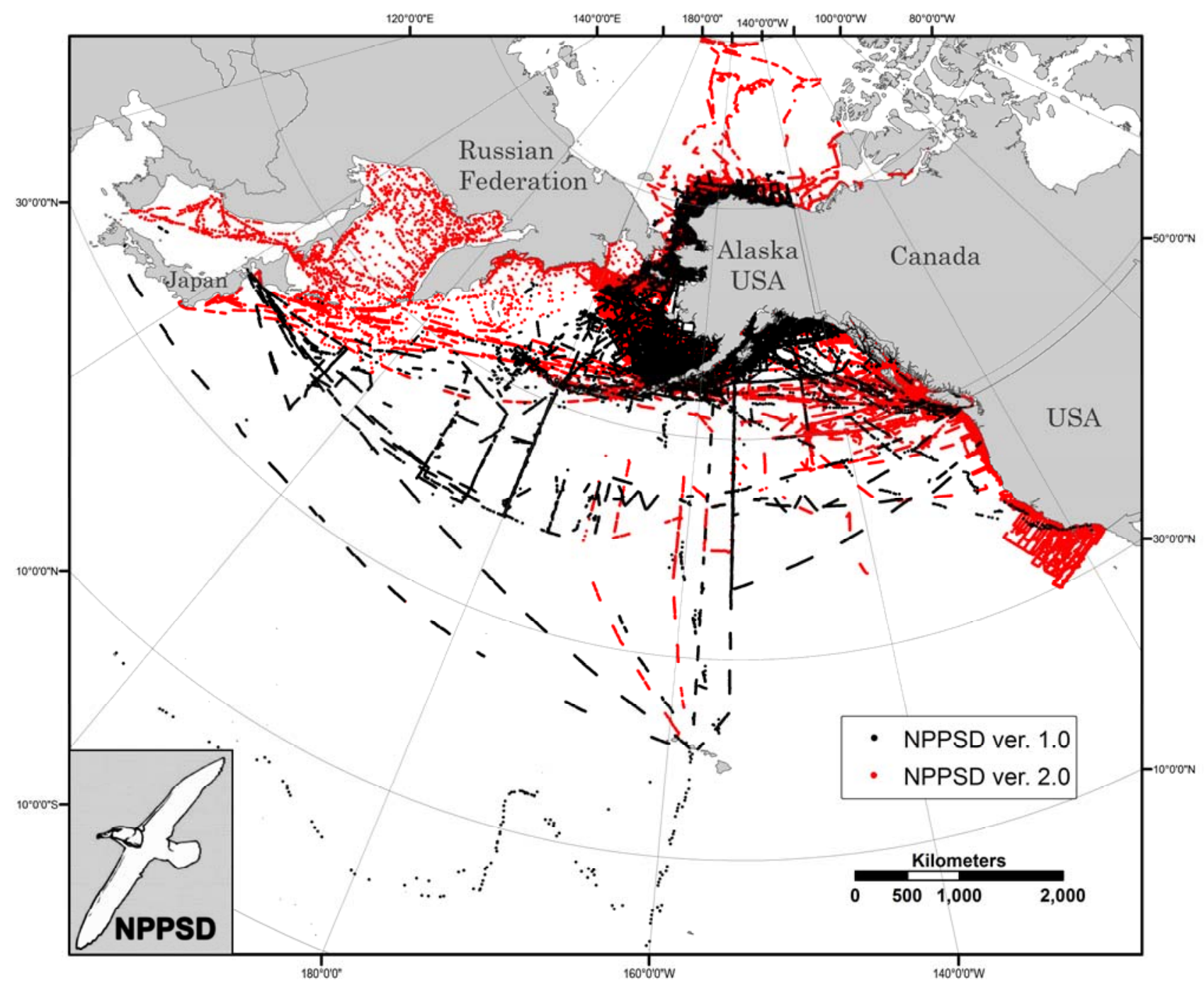

Figure 2. Geographic coverage of the North Pacific Pelagic Seabird Database (NPPSD). Sample points include the NPPSD version 1.0 and new samples added in the NPPSD version 2.0. Note that some new samples may be obscured by the samples from NPPSD 1.0 in some areas. 
Table 1. Spatial distribution of pelagic seabird survey data (effort and observations) in the North Pacific Pelagic Seabird Database 2.0.

\begin{tabular}{lcc}
\hline \multicolumn{1}{c}{ General area } & $\begin{array}{c}\text { Surveyed area } \\
\text { (square kilometers) }\end{array}$ & Sample transects \\
\hline Arctic Ocean & 9,861 & 8,572 \\
Aleutian Islands & 9,882 & 13,521 \\
Beaufort Sea & 11,570 & 7,180 \\
Bering Sea & 74,661 & 87,452 \\
California Current & 31,349 & 66,717 \\
Chukchi Sea & 15,468 & 14,879 \\
Eastern North Pacific & 51,438 & 57,880 \\
Western North Pacific & 47,164 & 81,459 \\
Coastal Gulf of Alaska & 12,104 & 12,481 \\
Sea of Japan & 1,743 & 405 \\
Sea of Okhotsk & 5,019 & 1,128 \\
\hline Total & 270,259 & 351,674 \\
\hline
\end{tabular}

\section{Database Structure}

The most notable change in NPPSD 2.0 was the change from flat-file to relational-database format. The NPPSD 1.0 used a flat-file format that was simple and made it easy for users without database experience to select data. The volume of new data - a nearly five-fold increase in samplesmade the previous flat-file format inefficient. The NPPSD 2.0 also was designed to minimize the redundancy found in version 1.0 of the database. This approach reduced storage requirements while giving the end-user more control over sample selection based on fields (for example, observer platform). The database was constructed with two tables: "tbl_LOCATION," hereafter referred to as the "location table," and "tbl_DATA_OBS," hereafter referred to as the "observation table." The location table provides a unique identifier, the spatial location and information on survey methods and conditions. The observation table contains information on the species, behavior, and number of marine birds and marine mammals. The two tables are linked by the Master Key field in both tables. Once in the new table structure, another round of proofing was conducted on both tables enabling us to identify and address numerous errors that had been missed in the initial examination as well as those that may have been a product of the conversion and reformatting process.

Production of the NPPSD 2.0 involved three developmental steps-(1) data acquisition (that is, gathering, documenting and archiving of datasets); (2) formatting and proofing (that is, correcting and standardizing data in location and observation tables); and (3) consolidation (that is, merging all surveys in a single relational database) (fig. 3). Treatment of data evolved between versions 1.0 and 2.0 , with the greatest accommodation needed for the basic differences in the way data were collected in early decades compared to later decades. For example, much of the NPPSD 1.0 data were in the form of discrete samples (for example, in 10-minute counts) and in the OCSEAP multiple three-table format; whereas much of the NPPSD 2.0 data were in the form of a single table of continuously recorded data, which had to be binned into discrete samples. Both data types yielded similar final tables, but the steps in developing those tables differed. 


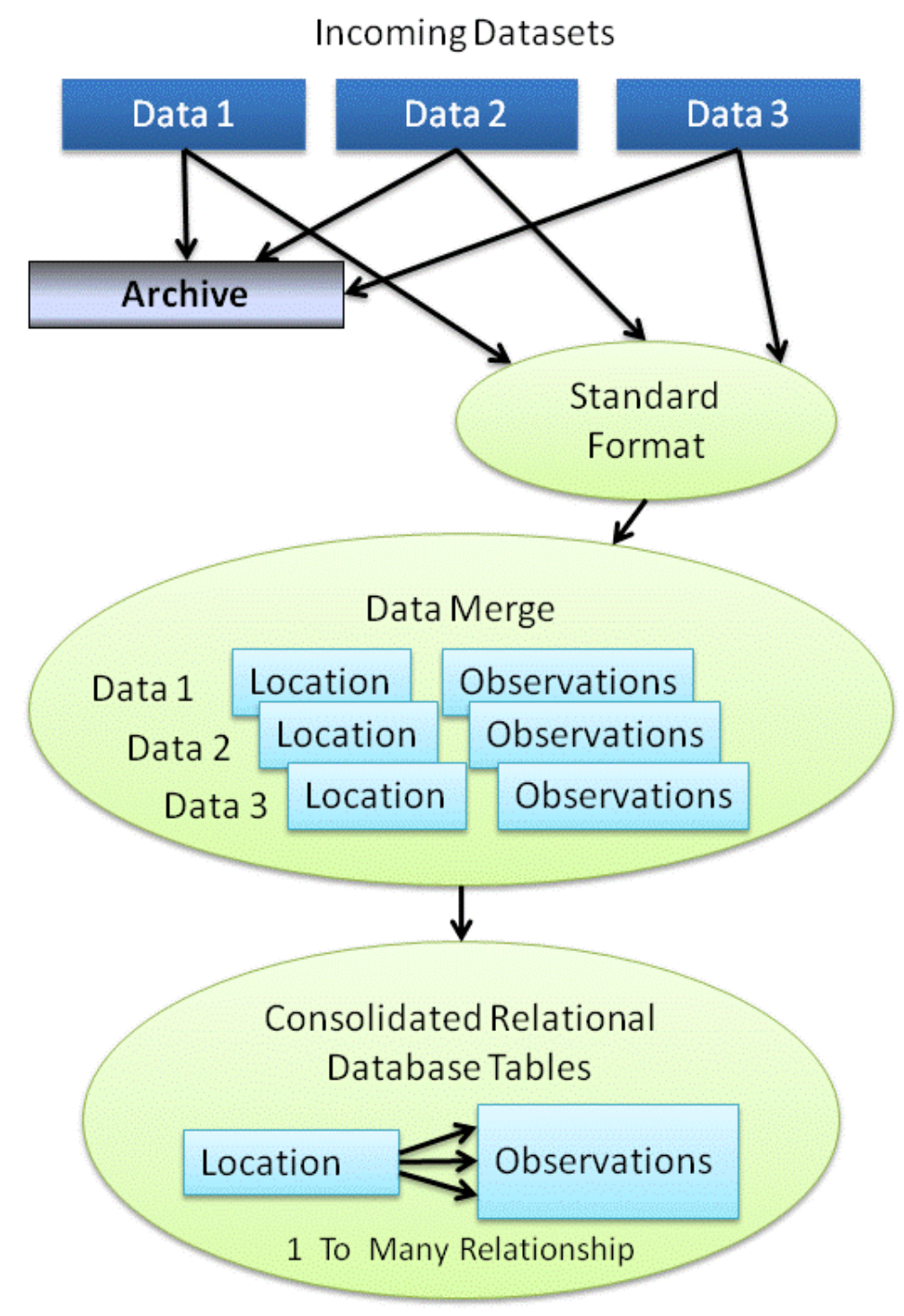

Figure 3. Conceptual model of North Pacific Pelagic Seabird Database processing and structure. Three rectangular boxes at the top of the model signify raw datasets, ellipses signify specific processes, and rectangular boxes inside ellipses signify data tables in the database. 
Each dataset was imported into a relational database table for review. The data then were proofed using the highest standards possible given the metadata available for each survey. Simple queries were applied to identify values that were out of range. Corrections often could be made for obvious typographical errors. When no information was available for an out-of-range value, the contributor was queried (when possible). Where a value was outside the possible range (for example, a vessel speed of $300 \mathrm{~km} / \mathrm{h}$ ), and it was not possible to identify correct values through the contributor, the field was left blank. Datasets generally had little documentation, so contributors were contacted to address questionable or missing data values. Because data structure varied between surveys (for example, summarized by transect or continuous counts), contributed datasets were reorganized and queries were applied to standardize data into uniform fields, formats, and units. The results of these efforts were standardized tables that could be combined into a new relational database (fig. 3).

\section{Taxonomic Codes}

During creation of the NPPSD, numerous inconsistencies in use of species codes were identified. These inconsistencies could be traced back to two factors-(1) user-specific species codes, and (2) taxonomic changes. Different researchers often used different codes for the same taxa. This led to unnecessary confusion and increased the chances that errors would be introduced into the database. Additionally, the taxonomic status of some species has changed since the data were collected, leading to issues with legacy. For example, when taxonomy has split a species into two taxa, the "new" taxonomy will only be reflected for data collected after the change. It is essential that researchers understand that observations for one of these newly recognized species cannot be separated for previously collected data. These issues made the development of a current comprehensive code list for North Pacific at-sea surveys essential (appendix C).

We used the current American Ornithological Union bird species list (Pyle and DeSante, 2009) as a starting point for NPPSD 4-letter codes, and added unique codes for missing marine bird and marine mammal species. The NPPSD taxonomic code list 2.1 (appendixes C and D) includes the Integrated Taxonomic Information System (ITIS) (2013) Taxonomic Serial Number, scientific name, common name, NPPSD 4-letter code, and the National Oceanographic Data Center (NODC) (1996) Taxonomic Code Version 8. The NODC Taxonomic Code list is not current; it has not been updated since 1996, but it was taxonomically ordered. As such, the list remains a useful tool for sorting. In cases where species taxonomy has changed, additions were made to the NODC codes to reflect the new order. These added codes end in "99". This range of crosswalked standards maximized accuracy while ensuring compatibility with incoming data.

The NPPSD taxonomic code list for marine birds and mammals in the North Pacific is available on the NPPSD Web site. Because bird names will continue to change as new data strengthens our understanding of taxonomy, we view the code list as a dynamic document and expect both new additions and future revisions. All data in the NPPSD 2.0 have been reconciled with the current NPPSD taxonomic code list. We recommend that researchers adopt the NPPSD taxonomic code list, as it will facilitate the future integration of new datasets into the NPPSD. Updates to the code list will be posted on the NPPSD products page. 


\section{Location Table}

In the location table, each record was unique, providing spatial and temporal information as well as details relevant to the sample transect (table 2). If a record failed to provide a latitude and longitude, the record was excluded. Latitude and longitude positions for each transect represent either the starting point (primarily before 1991) or transect centroid. Starting points were used when end of transect locations were not provided. These surveys were assumed to have been collected using the North American Datum of 1927 (NAD 27) and were converted to the World Geodetic System of 1984 (WGS 84). Data collected after 1990 were assumed to have been collected using a Global Positioning System (GPS) receiver set to the North American Datum of 1983 (NAD 83) or WGS 84 datums. The differences between NAD 83 and WGS 84 datums are well below the accuracy range of most GPS receivers (on the order of a few meters,) so they were treated as identical. For most datasets collected after 1990, contributors either provided the centroids or we were able to use a geographic information system (GIS) to extract the middle point of the transect from the provided track data. Some latitudelongitude locations were typographical errors (for example, over land), and were approximated using prior and following transect locations. If there were insufficient data to correct the point, then the record was excluded. The position type (start or centroid) is provided in the database. A sample area was calculated from the data that were provided. If a sample area could not be calculated for a record because of missing data (for example, transect length), this field was left blank. In these cases, the lack of sampled area also precludes the calculation of densities in the observation table $(n=3260 ;<1$ percent of transects). Environmental information (for example, sea-surface temperature) collected on surveys was included when provided; however, most transects lacked this information. If any data fields were missing, these fields were left blank, with the exception of the Contributor field, where blank fields were replaced with "Unknown."

Most fields in the location table are self-explanatory; however, there are several exceptions. Some fields were the result of calculations or classifications and required further description. Additionally, although numerous environmental fields are in the location table, such data were not available for most surveys. Surveys with environmental data tend to be those collected under the OCSEAP. Detailed explanations for a subset of the location table fields are as follows:

Master Key-The Master Key field provides the link between the location and observation tables. For the NPPSD 2.0, we used the Master Keys from the NPPSD 1.0, and those provided by contributors of new datasets. By using these "legacy" values, we retained the link to original datasets. The only requirement was that the Master Key be a unique identifier of each sample location. The location and observation tables were joined using the Master Key field with a one-to-many relationship. Thus, each record in the location table was unique but could be associated with multiple or no observation records in the observation table.

Survey ID_Additional survey identifier associated with incoming data. This field often is not unique and primarily is useful for linking back to raw datasets.

Station Number-Optional field included in some surveys that identifies a specific location. This field was provided in some surveys by researchers collecting repeated samples over time and is included for their benefit. 
Modified Platform Type-We recognized five different platform types, adopted from OCSEAP-U.S. Fish and Wildlife (FWS) protocols (Gould and Forsell, 1989): (1) Aircraft, (2) Land, (3) Large Boat, (4) Small Boat, and (5) Station. Most samples were from Large Boats $(>20 \mathrm{~m})$ and Small Boats $(<20$ $\mathrm{m})$. Land and station samples do not have a sample area and, therefore, do not have a density associated with a sample area. This field can be used to filter out samples that may be inappropriate for certain species or analyses. For example, aircraft-based surveys might be excluded for assessments of small species that are difficult to see or identify. Stations are a unique category indicating a fixed site; for example, an anchored ship or drilling platform. There are relatively few station data, all from OCSEAP years of study.

Modified Survey Type-Most of the data were classified as "Pelagic Survey." Some survey types were not specified, but they were assumed to be pelagic surveys when they included transect duration, width, and distance. During the OCSEAP data collection there also were station surveys, where species were counted in a fixed area (from a non-moving platform) over a fixed time period. These stations do not have a sample area, so they are automatically excluded from density calculations. The survey type "Off Transect Observation" is used only on a few samples from the OCSEAP data. No sample area is associated with these samples, and they are automatically excluded from density calculations. These observations will be included in exports of counts unless filtered out.

Survey Target-Identifies surveys as "All" (all species recorded) or taxa-specific. In the NPPSD 2.0, the only taxa-specific surveys in the NPPSD are for Brachyramphus spp. and Kittlitz's murrelets. Fly-Bird Method-This field distinguishes between surveys that use the "snapshot" method (Tasker and others, 1984) of counting flying birds passing through the sample area from surveys that use alternate methods. In most surveys, flying birds were counted at regular intervals (snapshots), not continuously, to minimize overestimation of bird densities owing to the flux of rapidly moving birds across the transect (Tasker and others, 1984; Gould and Forsell, 1989). However, in some surveys, flying birds were counted continuously. Although it is accepted that counting all flying birds will lead to overestimates of density, the amount of bias will vary by species, behavior, and flight direction (Spear and others, 2004). Given the generally high variability of at-sea survey densities, and the high proportion of observed birds sighted while sitting on the water, this bias should not preclude comparisons of these data in most cases. The exception may be in the counts of birds rarely seen sitting on the water (for example, storm petrels). The methodology used for counting flying birds ("continuous" or "snapshot") was included in the NPPSD data table so users could decide how to treat and interpret the resulting counts. If the counting methodology was not specified, it was recorded as "Unknown." The user is cautioned that combining continuous and snapshot samples without further correction may not be appropriate for all analyses and results will vary by species. Users may use only birds not flying, both methods combined, or they may export flying birds separately for each methodology (continuous or snapshot) and apply their own correction factors. The user is responsible for handling such corrections.

Loc Method-This field provides details on the method used to determine the latitude-longitude location of the sample. Much of the OCSEAP data forming the core of the NPPSD 1.0 data contain only the latitude and longitude recorded at the beginning of the transect. For most of the post-OCSEAP data, the latitude and longitude locations are based on the centroid of the sample transect.

Lat-Latitude of the sample location in decimal degrees using the WGS 84 datum.

Lon-Longitude of the sample location in decimal degrees using the WGS 84 datum. These longitudes are based on a -180 to 180 degree coordinate system. The 180th meridian runs through the middle of the NPPSD study area; thus, the dataset includes both positive and negative longitudes. 
Sample Area-A critical element of the location table was the calculation of the area sampled. This element was required to determine bird densities at sea (number of birds per $\mathrm{km}^{2}$ ). Sample areas were calculated in one of four ways, in descending order of accuracy-(1) the contributors provided an accurate sample area based on their own calculations from GPS data; (2) we calculated area as a product of transect length (or bin length) measured from a GPS source times transect width; (3) we calculated area as a product of transect length (calculated from vessel speed and elapsed time) times transect width; and (4) if none of the previous data sources were available and we had a beginning and an end location (lat-lon), we calculated the minimum distance between start and stop, and multiplied it by transect width to calculate area. Records where no sample areas could be calculated cannot be used for density calculations.

Table 2. Fields and data descriptions of the location table ("tbl_Location") of the North Pacific Pelagic Seabird Database.

\begin{tabular}{|c|c|}
\hline Field name & Description \\
\hline Master Key & Up to 25-digit unique identifier linking locations to observations \\
\hline Survey ID & Identifier for survey; for example, "Semidi Islands 2006" \\
\hline Station Number & Number for each transect or station within a Survey ID \\
\hline Modified Platform Type & Small Boat, Large Boat, Land, Station, or Aircraft \\
\hline Modified Survey Type & Pelagic Survey, Station, or Unk (Unknown) \\
\hline Survey Target & Either "All" or a specific species or taxa \\
\hline Fly-Bird-Method & All or Snapshot \\
\hline Loc Method & Start (start of transect), Centroid (midpoint of transect) \\
\hline Lat & Lat - Decimal Degrees \\
\hline Lon & Lon - Decimal Degrees \\
\hline Year & Year YYYY \\
\hline Month & Month 1-12 \\
\hline Day & Day of month $1-31$ \\
\hline Julian Day & Julian Day 1-366 \\
\hline Hour & Local Time Hour 0-23 \\
\hline Minute & Minute $0-59$ \\
\hline Elapsed Time & Minutes sampled \\
\hline Transect Width & Strip (bin) width in meters \\
\hline Speed & Average boat speed over bin in kilometers per hour \\
\hline Source & Dataset provider \\
\hline 3, L\&WGW & Contributing Scientist or Agency \\
\hline Depth & Depth in meters \\
\hline Surface Temperature & Temperature in ${ }^{\circ} \mathrm{C}$ \\
\hline Surface Salinity & Surface salinity, to nearest tenth of a part per thousand (psu) \\
\hline Barometric Pressure & Barometric pressure to nearest tenths of a millibar (haPa) \\
\hline Barometric Trend & 0 -steady, + rising, or - falling \\
\hline Wind Speed & In meters per second \\
\hline Sea State & Beaufort Scale assumed \\
\hline Weather & subjective not standardized \\
\hline Sample Area & Area of bin in square kilometers \\
\hline
\end{tabular}




\section{Observation Table}

The observation table contains records with information regarding species, number observed, behavior, etc. (table 3). There may be multiple observations at a given location, so multiple records may share the same "Master Key." Although every effort was made to double-check data with the data contributor on species that were rare, difficult to identify, or seemingly beyond normal distribution range, we were often unable to verify unusual records. Nor did we presume to second-guess the species identifications made by individual observers. Therefore, observations of very rare, difficult to identify, or vagrant species should be used with caution. In addition to raw counts, density calculations (sample count/sample area) for each transect were stored in the observation table to increase the speed of queries; however, when binning data, density should be recalculated (total count in bin/total sampled area in bin). Common name and the NPPSD 4-letter code were included for each record.

As with the location table, most fields in the observation tables are self-explanatory. An exception is the treatment of "off-transect" observations. Although these observations could not be used to calculate densities, they were retained in the data tables to preserve rare sightings or to determine the spatial distribution (range) of species. Additional descriptions for several fields are as follows:

Master Key-This field links "Observations" to the location table using a many (observations)-to-one (location) relationship. Thus, in the observation tables, this field is not necessarily unique. Each Master Key may have many or no observations, so it may be repeated or absent in the Data table. If there are no observations, the cross-tabulation will return a zero for "SumOfNumber" and "Density."

Density - This field is calculated from taking the SumOfNumber value in this table and dividing it by the Sample Area from the associated location table record. If there are no observation records for a location record, a cross-tabulation with the location table will return a zero density for all species for that sample. Only "on transect" counts are included in the density calculation. See "Modified Behavior" below for how behaviors were treated as on or off transect.

NPPSD 4-Letter Code-Although somewhat redundant with common names, the 4-letter codes are used commonly by bird researchers for convenience, brevity, and compatibility (dbf format truncates field names to 10 characters, and that can result in duplicate field names). Note that both common name and 4-letter codes are filtered through the NPPSD taxonomic code list to standardize them among surveys.

Modified Behavior-A large number of behaviors were reported in raw datasets by various investigators. We selected a small number of broad categories and converted codes used by others to the closest equivalent. The categories are:

Feeding —exhibiting foraging behavior indicative of active feeding

Fish —on the water holding fish in bill

Flying —all flying birds not exhibiting active feeding behavior

Water-sitting on water

Unk-no behavior recorded, assumed to be on water in most cases

Boat-sitting on boat (these are treated as off-transect and not used for densities)

Dead - (these are treated as off-transect and not used for densities)

Land-on land (these are treated as off-transect and not used for densities)

OT-OBS-This field was added in this version of the NPPSD to ensure that rare "off-transect observations" (that is, out of the sampling area) were retained. In addition to rare sightings, Modified Behavior of "Boat", "Dead", and "Land" also were classified as OT-OBS. 
Table 3. Fields and descriptions of the observation table ("tbl_Data_Obs") of the North Pacific Pelagic Seabird Database.

[Note The Master Key is not unique in this table. A given Master Key (sample location) may have multiple or no associated records in the observation table depending on the species observed.]

\begin{tabular}{ll}
\hline \multicolumn{1}{c}{ Field name } & \multicolumn{1}{c}{ Description } \\
\hline Master Key & Up to 25-digit identifier used to link location table to observations \\
Common Name & Common name of species observed \\
Density & Number per square kilometer for a given species, behavior, OT-OBS combination. \\
SumOfNumber & Sum of a given species with similar behavior at this location \\
NPPSD 4-Letter Code & NPPSD version 2.1 4-letter code \\
Modified Behavior & General behavior (see detailed description in text). \\
Source & Person transferring data \\
PI Credit & Contributing Scientist or Agency \\
OT-OBS & Off Transect Observation - Yes or No \\
Comments & Explanatory text-254-character limit \\
\hline
\end{tabular}

\section{Metadata for Contributed Surveys}

The amount of content information, or metadata, available for each survey was highly variable. Surveys collected prior to the adoption of a Federal metadata standard (before 1995) lacked any formal metadata documentation. We were able to gain access to many of the hardcopy data forms prior to 1995, making the extraction of metadata possible. Because future researchers may not have access to these originals or the researchers that collected the data, a considerable effort was made to extract metadata for these surveys. These original data sheets also were invaluable for proofing early datasets and identifying errors.

When metadata were provided for a contributed dataset, they were archived with the raw incoming data. Contributors now are required to include basic Federal Geographic Data Committee (FGDC) compliant metadata with contributed datasets.

\section{Metadata for the NPPSD 2.0}

For general reference purposes, metadata for the entire NPPSD 2.0 dataset are provided with the NPPSD dataset (https://dx.doi.org/10.5066/F7WQ01T3). 


\section{Database Contents}

\section{Biological Observations}

The NPPSD 2.0 was the result of combining many individual survey programs for marine birds in the North Pacific. These surveys contained 351,674 sample transects covering an area of 270,259 $\mathrm{km}^{2}$ and include the observations of 16,988,138 birds and 235,545 marine mammals. The 20 most abundant bird taxa are shown in table 4; a complete listing of all bird taxa counted and included in the NPPSD is shown in appendix C. Note that several of the taxa on the list are identified to a broader taxonomic class than species because of identification difficulties. The 20 most abundant marine mammals are shown in table 5. A complete summary listing of marine mammal observations in the NPPSD 2.0 is shown in appendix D.

Maps to identify species distributions can be created by selecting data from the database and binning it to the appropriate scale given the questions being addressed. Bins of NPPSD data can be created at any scale using a GIS, but at the scale of the North Pacific, $100 \times 100 \mathrm{~km}$ "cells" are most appropriate. As an example, a summary of Tufted Puffin counts per bin divided by the total sampled area within each cell provides an index of density illustrating the distribution of this species across its entire range (fig. 4).

\section{Sampling Effort}

Survey efforts varied greatly over time and space, and were concentrated in a few productive continental shelf areas and thinly distributed over a much larger area of the northern seas. The spatialtemporal variability in sampling reveals which areas are most useful for assessing long-term changes in bird communities, and which areas need more attention in the future. A map that includes all surveys binned into $50 \times 50 \mathrm{~km}$ cells reveals that effort was highly variable among areas, with the greatest sampling offshore of southern California, coastal British Columbia, southeastern and south-central coastal Alaska, and the eastern Bering Sea (fig. 5).

To examine the distribution of sampling efforts through time, the dataset was divided into four decadal periods: 1973-1982, 1983-1992, 1993-2002, and 2003-2012 (figs. 6A-6D). Each decadal period then was converted to a raster with a cell size of $50 \times 50 \mathrm{~km}$. The value (color) of the cell was equal to area sampled (in square kilometers) within each cell for these four time periods. Sampling intensity and extent varied widely across time periods (fig. 6). These map layers can be used as a guide for future research by identifying the sample availability for time periods of interest and (or) time spans. We overlaid the four periods and summed the number represented. When viewed this way, areas with extended temporal data are highlighted (fig. 7). The Bering Sea is the region with the most longterm data. Long-term data also are available for the Alaska Peninsula, southern British Columbia, and parts of the Aleutian Islands.

Temporal sampling efforts across years and seasons also were highly variable. At-sea sampling was relatively rare prior to the OCSEAP. The effect of that program can be seen in the rapid increase in sampling in 1975 (fig. 8). Since that time, sampling has varied in association with various programs and projects - for example, Exxon Valdez oil spill assessments after the 1989 spill and a large increase in sampling associated with the Bering Ecosystem Study and Bering Sea Integrated Ecosystem Research Program (2008-2014). Within-year sampling shows a seasonal bias, with the northern hemisphere summer breeding season (May-September) dominating the data records (fig. 9). 
Table 4. A listing of the 20 most abundant bird taxa in the North Pacific Pelagic Seabird Database 2.0.

\begin{tabular}{llc}
\hline \multicolumn{1}{c}{ Common name } & \multicolumn{1}{c}{ Scientific name } & Number of birds \\
\hline Unidentified Shearwater & Procellariidae spp. & $3,337,645$ \\
Short-tailed Shearwater & Puffinus tenuirostris & $2,093,018$ \\
Sooty Shearwater & Puffinus griseus & $1,295,024$ \\
Unidentified Murre & Uria spp. & $1,138,267$ \\
Northern Fulmar & Fulmarus glacialis & 967,698 \\
Least Auklet & Aethia pusilla & 867,946 \\
Long-tailed Duck & Clangula hyemalis & 763,392 \\
Crested Auklet & Aethia cristatella & 550,097 \\
Black-legged Kittiwake & Rissa tridactyla & 565,974 \\
Spectacled Eider & Somateria fischeri & 523,456 \\
Common Murre & Uria aalge & 509,546 \\
Tufted Puffin & Fratercula cirrhata & 337,745 \\
Glaucous-winged Gull & Larus glaucescens & 324,568 \\
Fork-tailed Storm-petrel & Oceanodroma furcata & 315,615 \\
Thick-billed Murre & Uria lomvia & 148,581 \\
Red Phalarope & Phalaropus fulicaria & 134,727 \\
Marbled Murrelet & Brachyramphus marmoratus & 122,575 \\
Unidentified Alcid & Alcidae spp. & 110,653 \\
Unidentified Phalarope & Phalaropus spp. & 107,746 \\
Unidentified Eider & Somateria or Polysticta spp. & 104,871 \\
\hline Total & & $14,319,144$ \\
\hline
\end{tabular}


Table 5. A listing of the 20 most abundant marine mammal species in the North Pacific Pelagic Seabird Database 2.0

\begin{tabular}{llc}
\hline Common name & Scientific name & $\begin{array}{c}\text { Number of marine } \\
\text { mammals }\end{array}$ \\
\hline Common Dolphin & Delphinus delphis & 64,017 \\
Sea Otter & Enhydra lutris & 29,885 \\
Steller Sea Lion & Eumetopias jubatus & 27,808 \\
Dall's Porpoise & Phocoenoides dalli & 20,086 \\
Pacific Walrus & Odobenus rosmarus divergens & 16,859 \\
Unidentified Dolphin & Unidentified Delphinidae & 13,495 \\
Harbor Seal & Phoca vitulina & 12,599 \\
Pacific White-sided Dolphin & Lagenorhynchus obliquidens & 9,832 \\
California Sea Lion & Zalophus californianus & 5,963 \\
Northern Fur Seal & Callorhinus ursinus & 5,774 \\
Risso's Dolphin & Grampus griseus & 3,607 \\
Unidentified Seal & Phocidae (Family) & 2,924 \\
Humpback Whale & Megaptera novaeangliae & 2,921 \\
Northern Right Whale Dolphin & Lissodelphis borealis & 2,853 \\
Harbor Porpoise & Phocoena phocoena & 2,302 \\
Gray Whale & Eschrichtius robustus & 1,752 \\
Killer Whale & Orcinus orca & 1,663 \\
Unidentified Whale & Cetacea (Order) & 1,658 \\
Spotted Seal & Phoca largha & 1,624 \\
Fin Whale & Balaenoptera physalus & 1,277 \\
\hline Total & & 228,899 \\
\hline & & \\
\hline & &
\end{tabular}




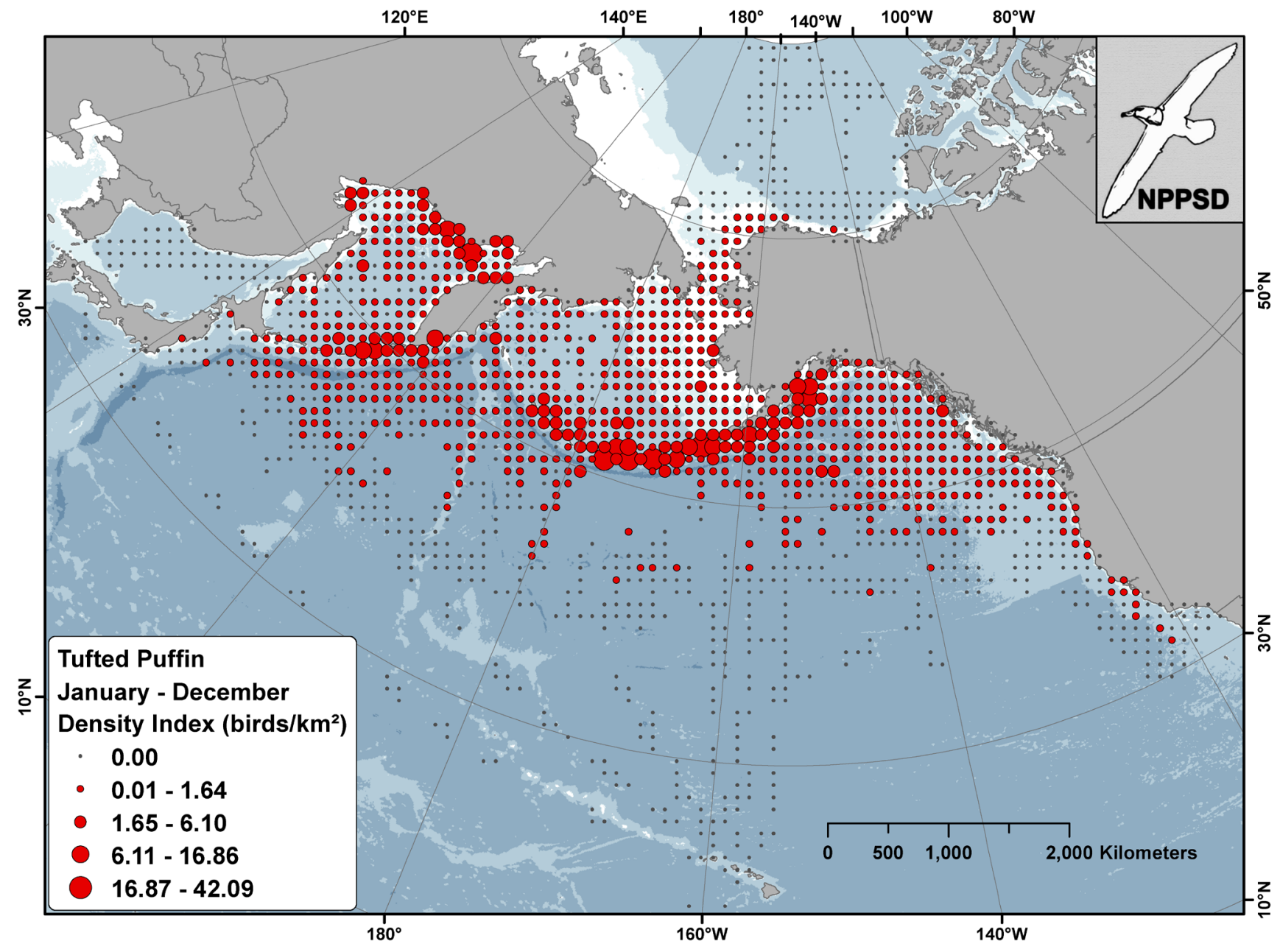

Figure 4. Density of Tufted Puffin across the North Pacific, 1973-2012. Data from the North Pacific Pelagic Seabird Database (NPPSD) were binned into 100 100 kilometer cells; total numbers were divided by total sampled area. Gray dots represent sampled cells with zero counts. 


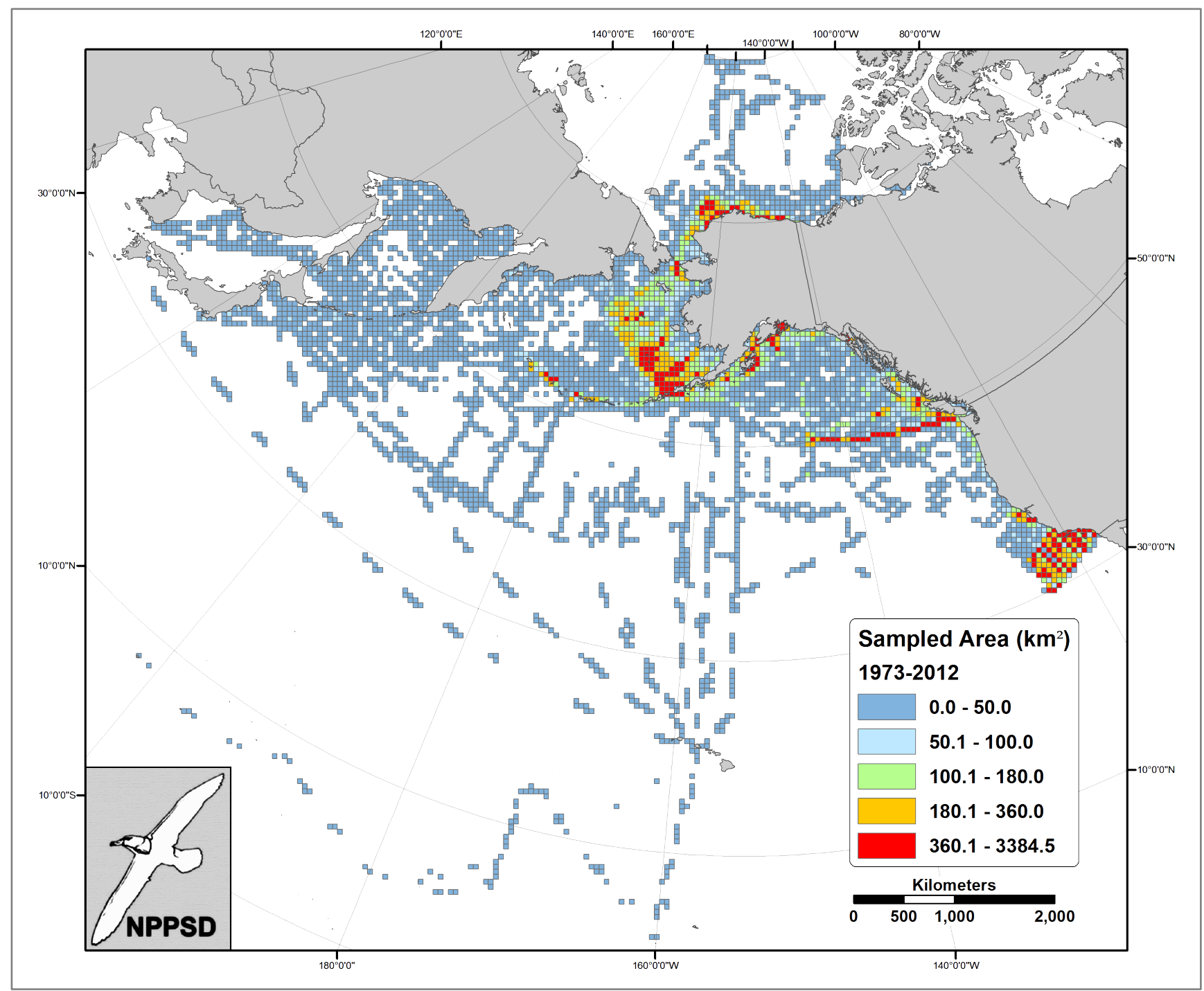

Figure 5. Distribution of samples (number of $\mathrm{km}^{2}$ surveyed) in the North Pacific Pelagic Seabird Database (NPPSD) version 2.0, 1973-2012. The area sampled within $50 \times 50$ kilometer cells was summed for all years. 


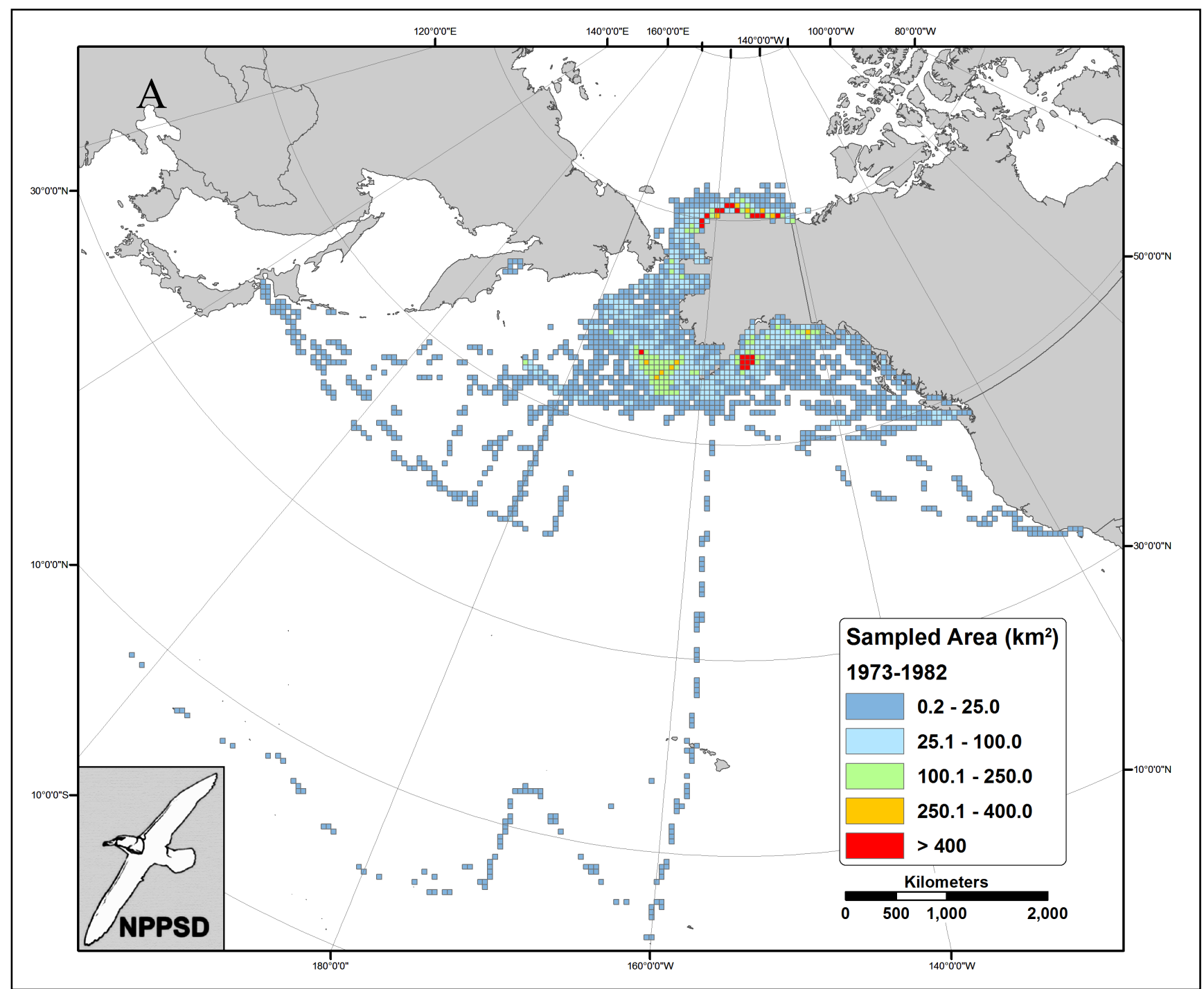

Figure 6. Sum of area sampled (number of km² surveyed) during four time periods $(A)$ 1973-1982, (B) 19831992, (C) 1993-2002, and (D) 2003-2012. Cells are $50 \times 50 \mathrm{~km}$. 


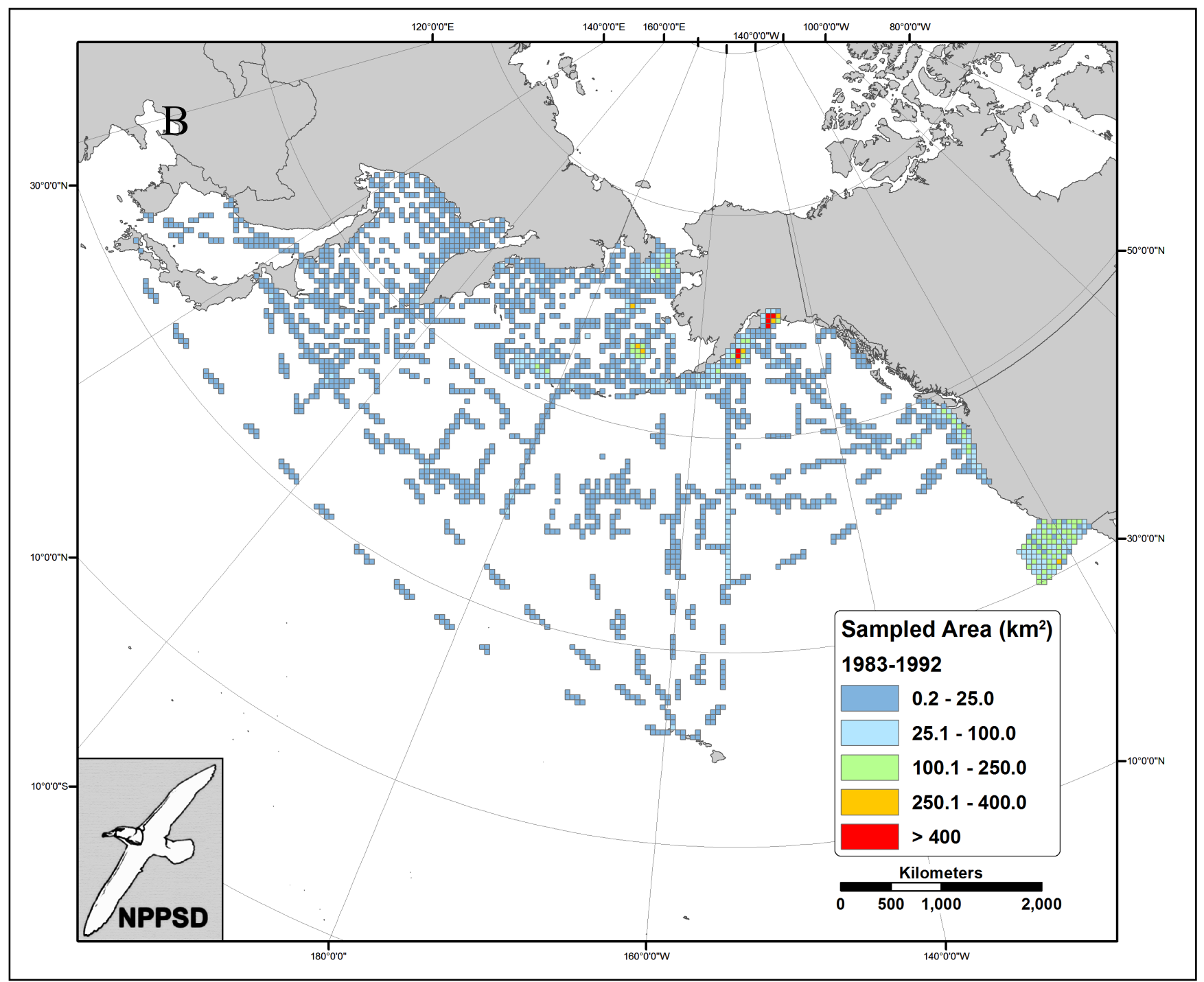

Figure 6. Continued. 


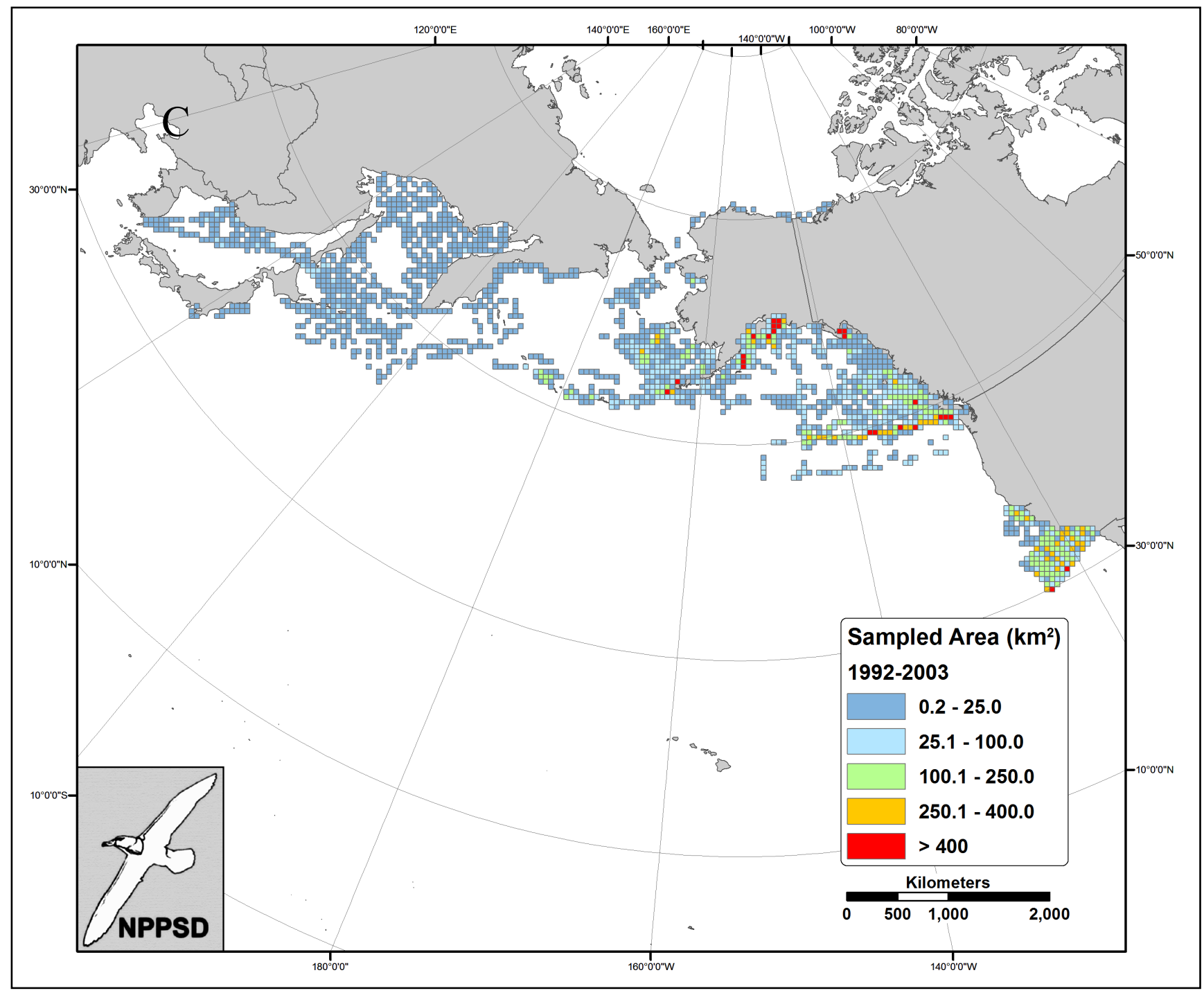

Figure 6. Continued. 


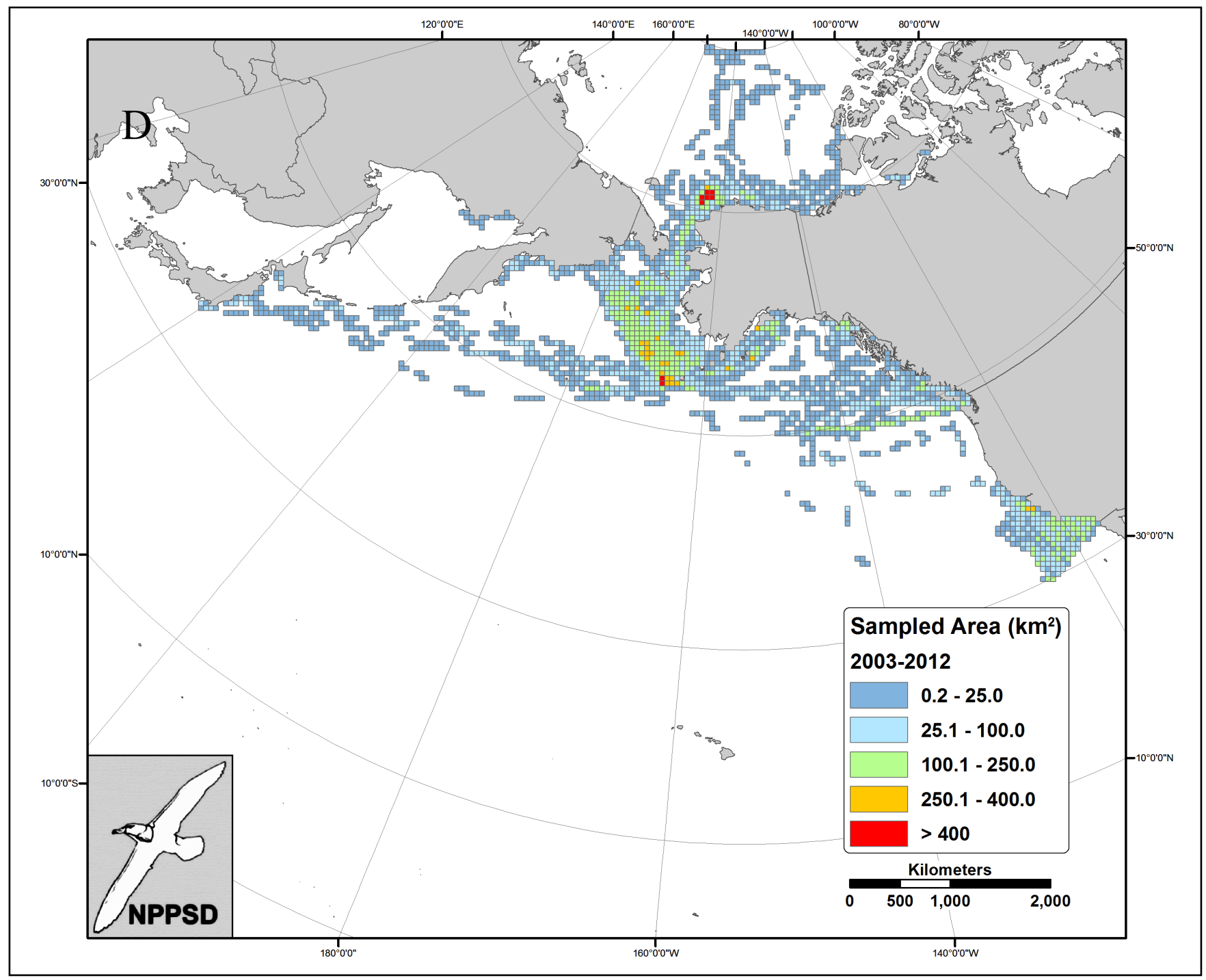

Figure 6. Continued. 


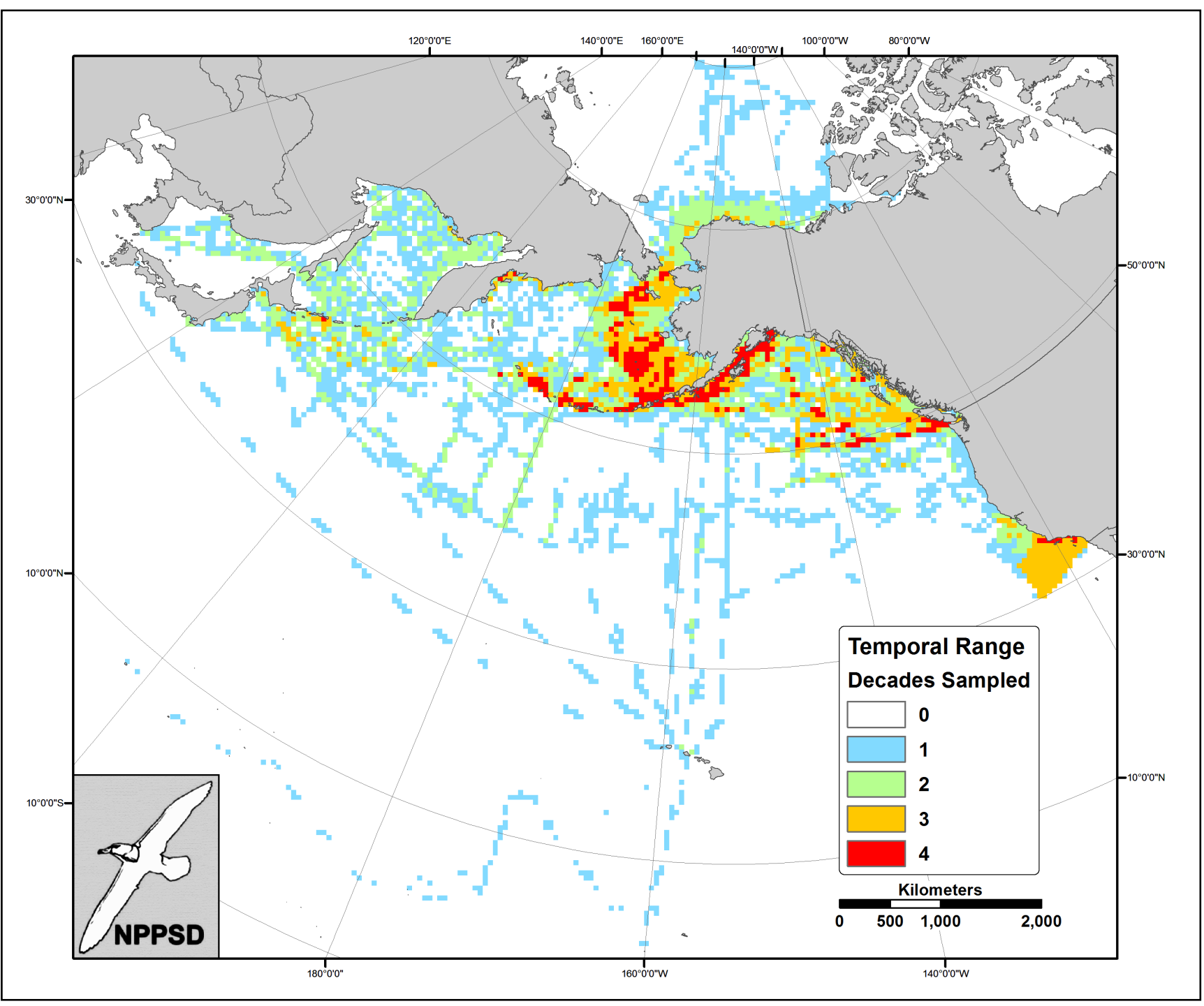

Figure 7. North Pacific Pelagic Seabird Database (NPPSD) version 2.0 sample representation across four decades-1973-1982, 1983-1992, 1993-2002, and 2003-2012. Cells are $50 \times 50 \mathrm{~km}$. Warmer colors indicate a longer sampling history. 


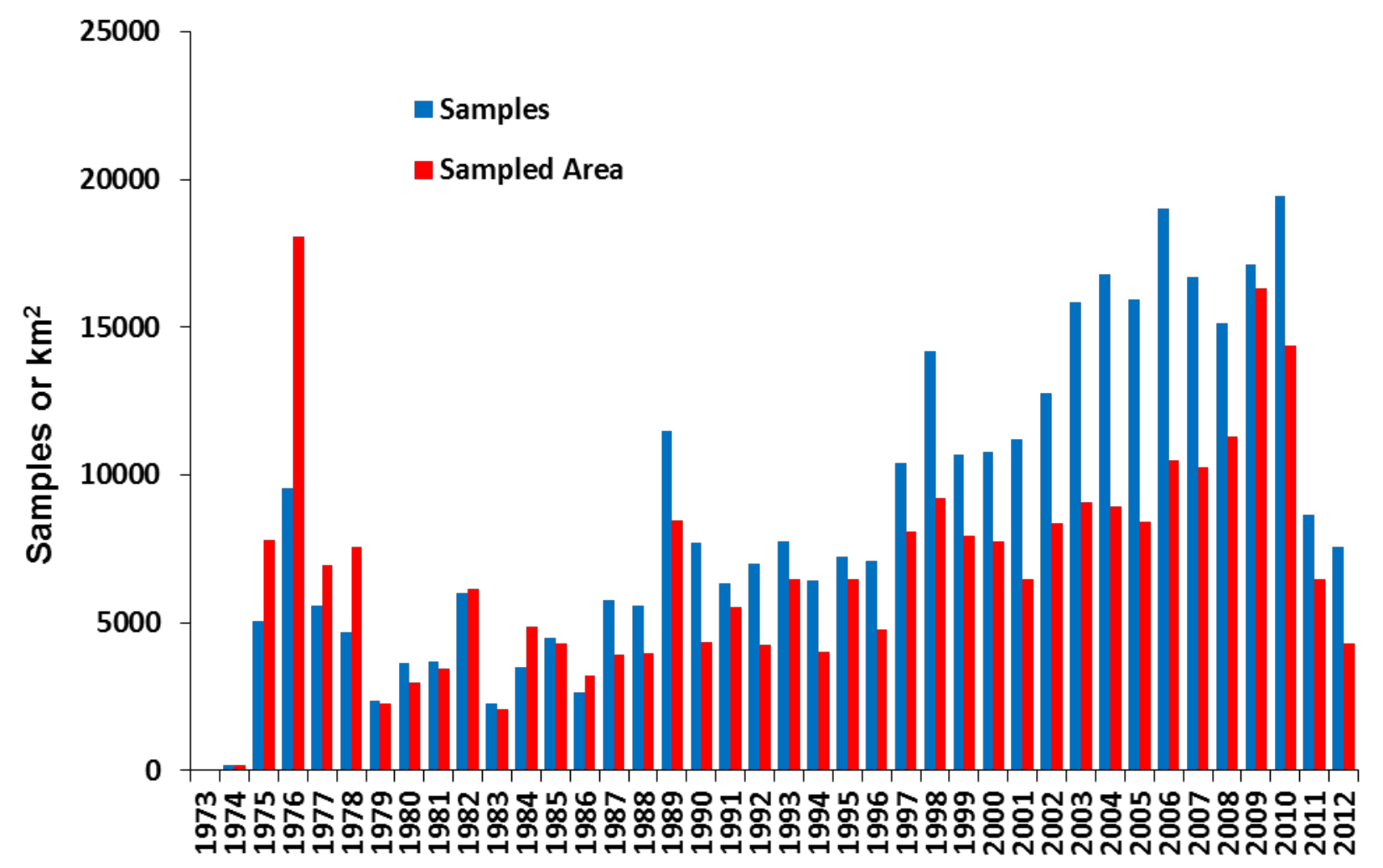

Figure 8. Numbers of monthly samples and sampled area for the North Pacific Pelagic Seabird Database (NPPSD), 1973-2012.

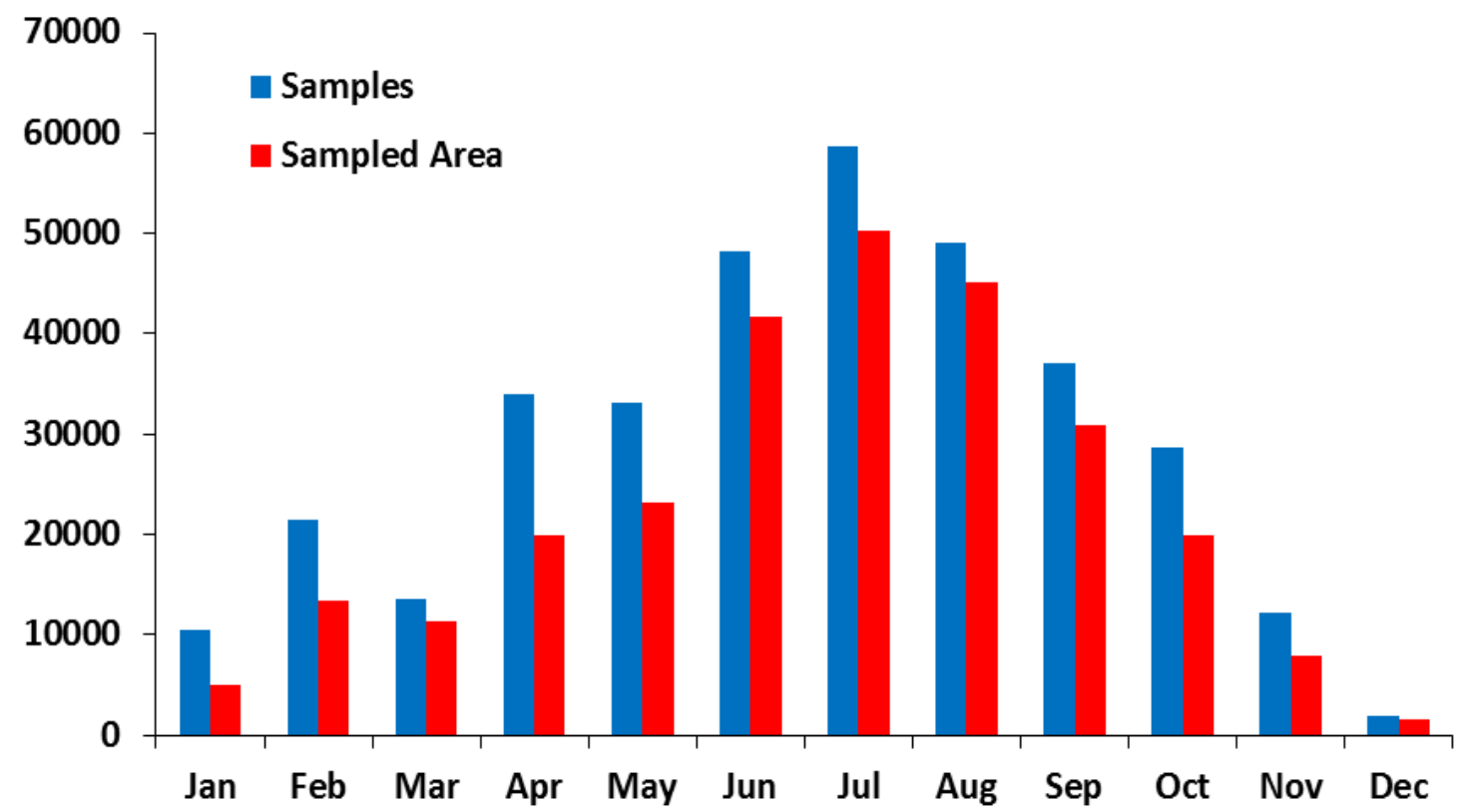

Figure 9. Graph showing numbers of monthly samples and sampled area for the North Pacific Pelagic Seabird Database (NPPSD), 1973-2012. 


\section{Summary}

This report provides documentation of the structure, scope, and limitations of the North Pacific Pelagic Seabird Database (NPPSD) 2.0. The NPPSD 2.0 is the largest database on marine birds and marine mammals at sea in the North Pacific, and is among the largest compilations of seabird distribution data in the world. This second version of the database represents a nearly five-fold increase in samples, while also substantially increasing the spatial and temporal range of the data. NPPSD 2.0 has expanded into previously underrepresented areas (for example, the Sea of Okhotsk and California), and has extended the time series of samples in some areas - notably the Bering Sea - to four decades. Spatial and temporal distributions, as shown in effort maps and temporal graphs, can assist researchers in determining the adequacy of the NPPSD to address specific questions. In conjunction with the current availability of broad-scale environmental datasets, the NPPSD 2.0 is a powerful tool to address broad-scale questions critical to the understanding of how climate change, regime shifts, and biogeography are associated with the distribution and habitat use of top marine predators. The database is available at https://dx.doi.org/10.5066/F7WQ01T3. To assist in the extraction of data from the NPPSD a query tool (appendix E) also is available on the NPPSD Web page on the USGS Alaska Science Center site (http://alaska.usgs.gov/).

Data from the NPPSD 2.0 already have been used in several publications since 2012. A complete list of products using the NPPSD (including version 1.0) is available on the NPPSD Web page on the USGS Alaska Science Center site. In addition to the database itself, the NPPSD taxonomic code list, available as a stand-alone product, provides a useful tool for standardizing data codes and crosswalking between various taxonomic conventions. Use of the NPPSD code list will assist in integrating new data quickly and accurately. This code list is a dynamic document that is periodically updated to represent current taxonomy. The most current version of this code list is available on the NPPSD Web page on the USGS Alaska Science Center site (http://alaska.usgs.gov/).

\section{Acknowledgments}

Development of NPPSD 2.0 was made possible by long-term support from the Wildlife Program of the U.S. Geological Survey Ecosystems Mission Area. The list of data collectors and contributors is long, and a full accounting is available from the metadata for the NPPSD. We thank all those observers for their long hours spent counting birds at sea, quite often during inhospitable conditions. A short list of major contributors to the NPPSD database (in addition to being major data collectors) includes: Vernon Byrd (U.S. Fish and Wildlife Service), Robert Day (ABR Inc.), Don Dragoo (U.S. Fish and Wildlife Service), R. Glenn Ford (Ecological Consulting, Inc., Portland, Oregon), George Hunt, Jr. (University of California-Irvine / University of Washington), David Irons (U.S. Fish and Wildlife Service), Kathy Kuletz (U.S. Fish and Wildlife Service), Kathleen Moore (Canadian Wildlife Service, Environment Canada), Ken Morgan (Canadian Wildlife Service, Environment Canada), Vjatcheslav Shuntov (Pacific Research Institute of Fisheries and Oceanography), Bill Sydeman (Farallon Institute), and Denny Zwiefelhofer (U.S. Fish and Wildlife Service). A complete list of contributors is available in appendix A. We are grateful to Anthony DeGange, Kathleen Moore, and Ken Morgan for reviewing this document and providing helpful comments to improve this manuscript. The North Pacific Research Board, U.S. Fish and Wildlife Service, and the U.S. Geological Survey, provided financial support to the NPPSD project. 


\section{References Cited}

Agler, B.A., Kendall, S.J., and Irons, D.B., 1998, Abundance and distribution of Marbled and Kittlitz's Murrelets in southcentral and southeast Alaska: Condor, v. 100, p. 254-265.

Agler, B.A., Kendall, S.J., Irons D.B., and Klosiewski, S.P., 1999, Long-term population changes of marine birds in Prince William Sound, Alaska: Waterbirds, v. 22,p. 98-103.

Ainley, D.G., Veit, R.L., Allen, S.G., Spear, L.B., and Pyle, P., 1995, Variations in marine bird communities of the California Current, 1986-1994: California Cooperative Oceanic Fisheries Investigations Reports, v. 36, p. 72-77.

Bond, A.L., Jones, I.L., Sydeman, W.J., Major, H.L., Minobe, S., Williams, J.C., Byrd, G.V., 2011, Reproductive success of planktivorous seabirds in the North Pacific is related to ocean climate on decadal scales: Marine Ecology Progress Series, v. 424, p. 205-218.

Burger, A.E., 1992, The effects of oil pollution on seabirds off the west coast of Vancouver Island, in

Vermeer, K., Butler, R.W., and Morgan, K, eds., The ecology, status and conservation of marine and shoreline birds on the west coast of Vancouver Island: Ottawa, Canadian Wildlife Service Occasional Paper No. 75, p. 120-128.

Croll, D.A., Tershy, B.R., Hewitt, R.P., Demer, D.A., Fiedler, P.C., Smith., S.E., Armstrong, W., Pop, J.M., Kiekhefer, T., Lopez, V.R., Urban, J., and Gendron. D., 1998, An integrated approach to the foraging ecology of marine birds and mammals: Deep-Sea Research Part II-Topical Studies in Oceanography, v. 45 , p. 1,353-1,371.

Diamond, A.W., and Devlin, C.M., 2003, Seabirds as indicators of changes in marine ecosystems: ecological monitoring on Machias Seal Island: Environmental Monitoring and Assessment, v. 88, p. $153-175$.

Drew, G., Dragoo, D., Renner, M., and Piatt, J.F., 2010, At-sea observations of marine birds and their habitats before and after the 2008 eruption of Kasatochi Volcano, Alaska: Arctic, Antarctic, and Alpine Research, v. 42, no. 3, p. 325-334.

Drew, G.S., and Piatt, J.F. 2005, North Pacific Pelagic Seabird Database (NPPSD) - Compiling datasets and creating an archive, accessible database, and pelagic seabird atlas-Final report for the North Pacific Marine Research Institute (NPMRI): U.S. Geological Survey, Alaska Science Center, Anchorage, Alaska, $38 \mathrm{p}$.

Drew, G.S., and Piatt, J.F., 2008, Using geographic information systems to compare non-uniform marine bird surveys-Detecting the decline of Kittlitz's Murrelet (Brachyramphus brevirostris) in Glacier Bay, Alaska: Auk, v. 125, p.178-182.

Drew, G.S., Piatt, J.F., and Hill, D.F., 2012, Effects of currents and tides in fine-scale use of marine bird habitats in a Southeast Alaska hotspot Marine Ecology Progress Series, v. 487, p. 275-286.

Elphick, C.S., and Hunt G.L., 1993, Variations in the distributions of marine birds with water mass in the northern Bering Sea. Condor 95: 33-44.

Ford, R.G., Page, G.W., and Carter, H.R., 1987, Estimating mortality of seabirds from oil spills, in Proceedings of the 1987 Oil Spill Conference, Washington, D.C.: American Petroleum Institute, p. 547-551.

Gould, P.J., and Forsell, D.J., 1989, Techniques for shipboard surveys of marine birds: U.S. Fish and Wildlife Service, U.S. Fish and Wildlife Technical Report 25, 12 p.

Gould, P.J., Forsell, D.J., and Lensink, C.J., 1982, Pelagic distribution and abundance of seabirds in the Gulf of Alaska and eastern Bering Sea: U.S. Fish and Wildlife Service, Biological Services Program, OBS 82/48, $294 \mathrm{p}$. 
Gould, P., and Piatt, J.F., 1993, Seabirds of the central North Pacific, in Vermeer, K., Briggs, K.T., Morgan, K.H., and Siegel-Causey, D., eds., The status, ecology and conservation of marine birds in the North Pacific: Ottawa, Canadian Wildlife Service Special Publication, p. 27-38.

Hunt, G.L., Drew, G.S., Jahncke, J., and Piatt, J.F., 2005, Prey consumption and energy transfer by marine birds in the Gulf of Alaska: Deep-Sea Research Part II-Topical Studies in Oceanography, v. 52, p.781-797.

Hyrenbach, K.D., Keiper, C., Allen, S.G., Ainley, D.G., and Anderson, D.J., 2006, Use of marine sanctuaries by far-ranging predators - Commuting flights to the California Current system by breeding Hawaiian albatrosses: Fisheries Oceanography, v. 15, no. 2, p. 95-103.

Integrated Taxonomic Information System, 2013, Integrated Taxonomic Information System: Integrated Taxonomic Information System database, accessed September, 22, 2013, at http://www.itis.gov.

Karpouzi, V., Watson, R., and Pauly, D., 2007, Modeling and mapping resource overlap between seabirds and fisheries on a global scale-A preliminary assessment: Marine Ecology Progress Series, v. 343 p. 87-99.

Klosiewski, S.P., and Laing, K., 1994, Marine bird populations of Prince William Sound, Alaska, before and after the Exxon Valdez oil spill-Exxon Valdez Oil Spill Trustee Council final report: U.S. Fish and Wildlife Service, Anchorage, Alaska.

Melvin, E.F., Wainstein, M.D., Dietrich, K.S., Ames, K.L., Geernaert, T.O., and Conquest, L.L., 2006, The distribution of seabirds on the Alaskan longline fishing grounds - Implications for seabird avoidance regulations: Washington Sea Grant Program, Project A/FP-7.

National Oceanographic Data Center , 1996, Taxonomic code version 8: National Oceanographic and Atmospheric Administration, National Oceanographic Data Center, accessed October 18, 2010, at http://www.nodc.noaa.gov/cgi-bin/OAS/prd/accession/details/50418.

Piatt, J.F., 1992, Mapping pelagic seabird distributions in Alaska in Alaska OCS Region Fourth Information Transfer Meeting Conference Proceedings, Anchorage, Alaska, January 28-20, 1992: Prepared for the U.S. Department of the Interior Minerals Management Service, Minerals Management Service OCS Study MMS 92-0046, p. 155-162.

Piatt, J.F., Arimitsu, M.L., Drew, G., Madison, E.N., Bodkin, J., Romano, M.D., 2011, Status and trend of the Kittlitz's Murrelet Brachyramphus brevirostris in Glacier Bay, Alaska: Marine Ornithology, v.39, p. 65-75.

Piatt, J.F., and Ford, R.G., 1993, Distribution and abundance of Marbled Murrelets in Alaska: Condor, v. 95, p.662-669.

Piatt, J.F., and Ford, G., 2001, Monitoring seabird populations in areas of oil and gas development on the Alaskan Continental Shelf-A computerized pelagic seabird atlas for Alaska, June 2000: Final Report to the U.S. Department of Interior Minerals Management Service, U.S. Geological Survey OCS Study, MMS 2000-072, 53 p.

Piatt, J.F., Harding, A.M.A., Shultz, M., Speckman, S.G., Van Pelt, T.I., Drew, G.S. and Kettle, A.B., 2007, Seabirds as indicators of marine food supplies: Cairns revisited: Marine Ecology Progress Series, v. 352, p. 221-234.

Piatt, J.F., Kuletz, K.J., Burger, A.E., Hatch, S.A., Friesen, V.L., Birt, T.P., Arimitsu, M.L., Drew, G.S., Harding, A,M.A., and Bixler, K.S., 2007, Status review of the Marbled Murrelet (Brachyramphus marmoratus) in Alaska and British Columbia: U.S. Geological Survey Open-File Report 2006-1387, 285 p.

Piatt, J.F., Lensink, C.J., Butler, W., Kendziorek, M., and Nysewander, D., 1990, Immediate impact of the Exxon Valdez oil spill on marine birds: Auk, v. 107 p. 387-397. 
Piatt, J.F., and Naslund, N.L., 1995, Abundance, distribution, and population status of Marbled Murrelets in Alaska, in Ralph, C.J., Hunt, G.L., Jr., Raphael, M.C., and Piatt, F.J., eds., Ecology and conservation of the Marbled Murrelet: Albany, California, U.S. Forest Service General Technical Report PSW-152, p. 285-294.

Piatt, J.F., and Springer, A.M., 2004. Advection, pelagic food webs, and the biogeography of seabirds in Beringia: Marine Ornithology, v. 31, p. 141-154.

Piatt, J.F., and Springer, A.M., 2007, Marine ecoregions of Alaska, in Spies, Robert, ed., Long-term ecological change in the northern Gulf of Alaska: Amsterdam, The Netherlands, Elsevier, p. 522526.

Piatt, J.F., Wells, J.L., MacCharles, A., and Fadely, B., 1991, The distribution of seabirds and their prey in relation to ocean currents in the southeastern Chukchi Sea: Ottawa, Canadian Wildlife Service Occasional Paper No. 68, p. 21-31.

Piatt, J.F., Wetzel, J., Bell, K., DeGange, A.R., Balogh, G.R., Drew, G.S., Geernaert, T., Ladd, C., and Byrd, G.V., 2006, Predictable hotspots and foraging habitat of the endangered short-tailed albatross (Phoebastria albatrus) in the North Pacific_-Implications for conservation: Deep Sea Research Part II-Topical Studies in Oceanography, v. 53, p. 387-398.

Pyle, P., and DeSante, D.F., 2009, Updates to four-letter and six-letter alpha codes based on revisions by the American Ornithologists' Union in 2009: North American Bird Bander, v. 34, p.109-110.

Renner, M., Arimitsu, M.L., and Piatt, J.F., 2012, Structure of marine predator and prey communities along environmental gradients in a glaciated fjord: Canadian Journal of Fisheries and Aquatic Sciences, v. 69, p. 2,029-2,045.

Renner, M., Hunt, G.L., Jr., Piatt, J.F., and Byrd, G.V., 2008, Seasonal and distribution patterns of seabirds along the Aleutian Archipelago: Marine Ecology Progress Series, v. 357, p. 301-311.

Renner, M., Parrish, J.K., Piatt, J.F., Kuletz, K.J., Edwards, A.E., and Hunt, G.L., Jr., 2013, Modeled distribution and abundance of a pelagic seabird reveal trends in relation to fisheries: Marine Ecology Progress Series 484, p. 259-277.

Smith, M., Walker, N.J., Free, C.M., Kirchhoff, M.J., Drew, G.S., Warnock, N., and Stenhouse, I.J., 2014, Identifying marine Important Bird Areas using at-sea survey data: Biological Conservation, v. 172 , p. $180-189$.

Spear, L. B., Ainley, D. G., Hardesty, B. D., Howell, S. N., \& Webb, S. W. 2004. Reducing biases affecting at-sea surveys of seabirds: use of multiple observer teams. Marine Ornithology, 32, p. 147157.

Springer, A.M., Piatt, J.F., Shuntov, V.P., van Vliet, G.B., Vladimirov, V.L., Kuzin, A.E., and Perlov, A.S., 1999, Marine birds and mammals of the Pacific Subarctic Gyres: Progress in Oceanography, v. 43, p. 443-487.

Tasker, M.L., Hope Jones P., Dixon T., and Blake, B.F., 1984, Counting seabirds from ships-A review of methods employed and a suggestion for a standardized approach: Auk, v. 101, p. 567-577. Veit, R.R., Pyle, P., and McGowan, J.A., 1996, Ocean warming and long-term change in pelagic bird abundance within the California current system: Marine Ecology Progress Series, v. 139, p. 11-18. 


\section{Appendix A. List of Contributors to the North Pacific Pelagic Seabird Database as Individuals, Program Managers, or Institutions}

[Note for the few contributions for which credit for data was not clear we used observer's name, which may not reflect the actual principal investigator. Contributors of more than 1,000 transects are indicated by an asterisk*; of more than 5,000 transects are indicated by two asterisks**. Additionally, affiliations refer to time of data collection and may not reflect current status]

\begin{tabular}{|c|c|}
\hline Contributor & Agency and affiliation \\
\hline Beverly Agler* & U.S. Fish and Wildlife Service, Region 7, Migratory Bird Management \\
\hline Vernon Byrd ** & U.S. Fish and Wildlife Service, Region 7, Alaska Maritime NWR \\
\hline Jeffrey Allen & U.S. Fish and Wildlife Service, Region 7 \\
\hline Patricia Baird & U.S. Fish and Wildlife Service, Region 7 \\
\hline James Bartonek & U.S. Fish and Wildlife Service, Region 7 \\
\hline Judith Benson & Unknown \\
\hline John Blackenship & Unknown \\
\hline Mike Bonnell* & Ecological Consulting, Inc., Portland, Oregon \\
\hline Ken T. Briggs* & Ecological Consulting, Inc., Portland, Oregon \\
\hline David Kline & U.S. Fish and Wildlife Service, Region 7 \\
\hline Robert Day** & ABR Incorporated \\
\hline Anthony DeGange* & U.S. Fish and Wildlife Service, Region 7 \\
\hline Matthew Dick & U.S. Fish and Wildlife Service, Region 7 \\
\hline George Divoky* & Institute of Arctic Biology, University of Alaska-Fairbanks \\
\hline Don Dragoo* & U.S. Fish and Wildlife Service, Region 7, Alaska Maritime NWR \\
\hline Gary Drew & U.S. Geological Survey, Alaska Science Center \\
\hline William Drury & College of the Atlantic, Maine \\
\hline Thomas Early & U.S. Fish and Wildlife Service, Region 7 \\
\hline R. Glenn Ford* & Ecological Consulting, Inc., Portland, Oregon \\
\hline Doug Forsell* & U.S. Fish and Wildlife Service, Region 7 \\
\hline David Frazer & U.S. Fish and Wildlife Service, Region 7 \\
\hline Robert Gill, Jr. & U.S. Fish and Wildlife Service, Region 7 \\
\hline Patrick Gould* & U.S. Fish and Wildlife Service, Region 7 \\
\hline G.A. Green* & G. A. Green, Ebasco Environmental \\
\hline Juan Guzman & University of Calgary, Canada \\
\hline Colleen Handel & U.S. Fish and Wildlife Service, Region 7 \\
\hline Craig Harrison* & U.S. Fish and Wildlife Service, Region 7 \\
\hline Scott Hatch* & U.S. Geological Survey, Alaska Science Center \\
\hline David Hardy & Alaska Department of Fish and Game \\
\hline Karen Henderson & Unknown \\
\hline Eric Hoberg & Epidemiology and Systematics Laboratory, U.S. Dept. of Agriculture \\
\hline George L. Hunt $* *$ & University of California-Irvine / University of Washington \\
\hline David Irons $* *$ & U.S. Fish and Wildlife Service, Region 7, Migratory Bird Management \\
\hline
\end{tabular}




\begin{tabular}{|c|c|}
\hline Contributor & Agency and affiliation \\
\hline Malcolm Isleib & Independent, Cordova, Alaska \\
\hline Robert Jones & U.S. Fish and Wildlife Service, Region 7 \\
\hline Matthew Kirchhoff & Alaska Department of Fish and Game \\
\hline Michelle L. Kissling & U.S. Fish and Wildlife Service, Region 7 \\
\hline Lynne Krasnow & U.S. Fish and Wildlife Service, Region 7 \\
\hline Kathy Kuletz ** & U.S. Fish and Wildlife Service, Region 7, Migratory Bird Management \\
\hline Richard MacIntosh & National Marine Fisheries Service \\
\hline Keith Metzner & U.S. Fish and Wildlife Service, Region 7 \\
\hline Alan Moe & U.S. Fish and Wildlife Service, Region 7 \\
\hline Kathleen Moore** & Canadian Wildlife Service, Environment Canada \\
\hline Ken Morgan** & Canadian Wildlife Service, Environment Canada \\
\hline Jay Nelson & U.S. Fish and Wildlife Service, Region 7 \\
\hline David Nysewander & U.S. Fish and Wildlife Service, Region 7 \\
\hline Mark Phillips & U.S. Fish and Wildlife Service, Region 7 \\
\hline John F. Piatt ** & U.S. Geological Survey, Alaska Science Center \\
\hline Point Blue ** & Private NGO - Previously Point Reyes Bird Observatory \\
\hline Mark Rauzon & U.S. Fish and Wildlife Service, Region 7 \\
\hline Jerry Ruehle & Alaska Department of Natural Resources \\
\hline Gerald Sanger & U.S. Fish and Wildlife Service, Region 7 \\
\hline Theodore Schad & U.S. Fish and Wildlife Service, Region 7 \\
\hline V. P. Shuntov* & Pacific Research Institute of Fisheries and Oceanography \\
\hline Arthur Sowls & U.S. Fish and Wildlife Service, Alaska Maritime NWR \\
\hline Suzann Speckman & U.S. Geological Survey, Alaska Science Center \\
\hline Michael Spindler & U.S. Fish and Wildlife Service, Region 7 \\
\hline Alaska Maritime NWR ** & U.S. Fish and Wildlife Service, Region 7 \\
\hline Migratory Bird Management** & U.S. Fish and Wildlife Service, Region 7 \\
\hline Alaska Science Center** & U.S. Geological Survey \\
\hline Irving Warner & Alaska Department of Fish and Game \\
\hline Ed Wickersham & U.S. Fish and Wildlife Service, Reg. 7, Kodiak NWR \\
\hline John Wells & Memorial University of Newfoundland \\
\hline John Wiens & University of Arizona \\
\hline Kent Wohl & U.S. Fish and Wildlife Service, Reg. 7 \\
\hline Denny Zwiefelhofer ** & U.S. Fish and Wildlife Service, Reg. 7, Kodiak NWR \\
\hline
\end{tabular}




\section{Appendix B. Map Showing Geographic Regions Used for Table 1}

The map is based in the North Pacific Marine Science Organization (PICES) map of North Pacific subregions, but includes several modifications to include areas outside current PICES subregions (Arctic Ocean, Chukchi Sea, and Beaufort Sea).

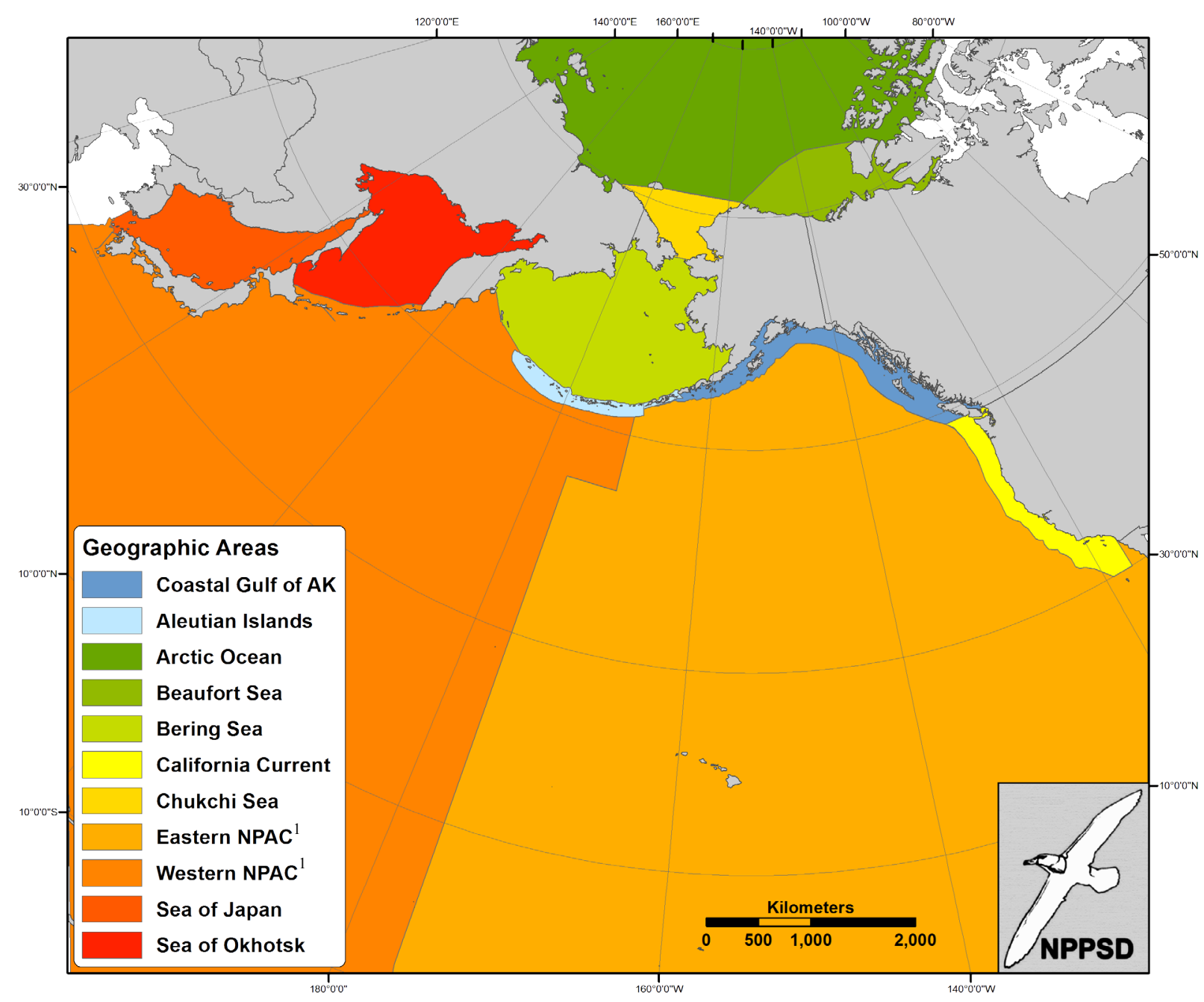

${ }^{1} \mathrm{NPAC}=$ North Pacific. 


\section{Appendix C. Bird Species from the North Pacific Pelagic Seabird Database (NPPSD) Taxonomic Code List 2.1}

The following table includes the National Oceanographic Data Center (NODC) Taxonomic Code list useful for sorting, as well as the more current Integrated Taxonomic Information System (ITIS) Taxonomic Serial Number (TSN).

\begin{tabular}{|c|c|c|c|c|}
\hline ITIS TSN & Scientific name & Common name & $\begin{array}{l}\text { NPPSD 4- } \\
\text { Letter Code }\end{array}$ & NODC Taxonomic Code \\
\hline 174371 & Aves (Class) & Unidentified Bird & UNBI & 91 \\
\hline 174468 & Gavia spp. & Unidentified Loon & UNLO & 91070101 \\
\hline 174469 & Gavia immer & Common Loon & COLO & 9107010101 \\
\hline 174470 & Gavia adamsii & Yellow-billed Loon & YBLO & 9107010102 \\
\hline 174471 & Gavia arctica & Arctic Loon & ARLO & 9107010103 \\
\hline 174474 & Gavia stellata & Red-throated Loon & RTLO & 9107010104 \\
\hline 174475 & Gavia pacifica & Pacific Loon & PALO & 9107010105 \\
\hline 174478 & Podicipedidae spp. & Unidentified Grebe & UNGR & 91080101 \\
\hline 174479 & Podiceps grisegena & Red-necked Grebe & RNGR & 9108010101 \\
\hline 174482 & Podiceps auritus & Horned Grebe & HOGR & 9108010102 \\
\hline 174485 & Podiceps nigricollis & Eared Grebe & EAGR & 9108010103 \\
\hline 554027 & Aechmophorus clarkii & Clark's Grebe & CLGR & 91080102 \\
\hline 174503 & Aechmophorus occidentalis & Western Grebe & WEGR & 9108010201 \\
\hline 174513 & Diomedeidae (Family) & Unidentified Albatross & UALB & 910901 \\
\hline 174515 & Diomedea albatrus & Short-tailed Albatross & STAL & 9109010101 \\
\hline 174516 & Diomedea nigripes & Black-footed Albatross & BFAL & 9109010102 \\
\hline 554378 & Phoebastria immutabilis & Laysan Albatross & LAAL & 9109010103 \\
\hline 174512 & Procellariiformes (Order) & Unidentified Procellariiformes & UNPR & 910902 \\
\hline 174536 & Fulmarus glacialis & Northern Fulmar & NOFU & 9109020201 \\
\hline 174532 & Puffinus spp. & Unidentified Shearwater & UNSH & 91090204 \\
\hline 174547 & Puffinus creatopus & Pink-Footed Shearwater & PFSH & 9109020402 \\
\hline 174548 & Puffinus carneipes & Flesh-footed Shearwater & FFSH & 9109020403 \\
\hline 174550 & Puffinus pacificus & Wedge-tailed Shearwater & WTSH & 9109020405 \\
\hline 174552 & Puffinus bulleri & Buller's Shearwater & BUSH & 9109020406 \\
\hline 174553 & Puffinus griseus & Sooty Shearwater & $\mathrm{SOSH}$ & 9109020407 \\
\hline 174554 & Puffinus tenuirostris & Short-tailed Shearwater & STSH & 9109020408 \\
\hline 174555 & Puffinus puffinus & Manx Shearwater & MASH & 9109020409 \\
\hline 174557 & Puffinus opisthomelas & Black-vented Shearwater & BVSH & 910902040902 \\
\hline 174558 & Puffinus auricularis & Newell's Shearwater & NESH & 9109020410 \\
\hline 174561 & Puffinus lheminieri & Audubon's Shearwater & AUSH & 9109020412 \\
\hline
\end{tabular}


Appendix C. Continued.

\begin{tabular}{|c|c|c|c|c|}
\hline ITIS TSN & Scientific name & Common name & $\begin{array}{l}\text { NPPSD 4- } \\
\text { Letter Code }\end{array}$ & NODC Taxonomic Code \\
\hline 174565 & Puffinus nativitatis & Christmas Shearwater & $\mathrm{CHSH}$ & 9109020414 \\
\hline N.A. & Pterodroma or Bulweria or Procellaria spp. & Unidentified Petrel & UNPE & $9109020499_{1}$ \\
\hline 174566 & Pterodroma spp. & Unidentified Pterodroma & UNPT & 91090205 \\
\hline 174569 & Pterodroma inexpectata & Mottled Petrel & MOPE & 9109020503 \\
\hline 174570 & Pterodroma arminjoniana & Herald Petrel & HEPE & 9109020504 \\
\hline 554395 & Pterodroma cookii & Cook's Petrel & COPE & 9109020505 \\
\hline 174573 & Pterodroma neglecta & Kermadec Petrel & KEPE & 9109020506 \\
\hline 174574 & Pterodroma externa & Juan Fernandez Petrel & JFPE & 9109020507 \\
\hline 554394 & Pterodroma cervicalis & White-necked Petrel & WNPE & 9.10902050702 \\
\hline 174577 & Pterodroma alba & Phoenix Petrel & PHPE & 9109020508 \\
\hline 562561 & Pterodroma sandwichensis & Hawaiian Petrel & HAPE & 9109020509 \\
\hline 174579 & Pterodroma hypoleuca & Bonin Petrel & BOPE & 9109020510 \\
\hline 174580 & Pterodroma nigripennis & Black-winged Petrel & BWPE & 9109020511 \\
\hline 174581 & Pterodroma solandri & Solander's Petrel & SOPE & 9109020512 \\
\hline 562560 & Pterodroma pycrofti & Pycroft's Petrel & PYPE & 9109020513 \\
\hline 174582 & Pterodroma longirostris & Stejneger's Petrel & STPE & 9109020513 \\
\hline 174588 & Pterodroma leucoptera & Gould's Petrel & GOPE & 9109020519 \\
\hline 174592 & Pterodroma ultima & Murphy's Petrel & MUPE & 9109020523 \\
\hline 174611 & Procellaria parkinsoni & Parkinson's Petrel & PAPE & 9109021002 \\
\hline 554144 & Bulweria bulwerii & Bulwer's Petrel & BUPE & 9109021201 \\
\hline 203449 & Calonectris leucomelas & Streaked Shearwater & STRS & 9109021302 \\
\hline 174619 & Hydrobatidae (Family) & Unidentified Storm-petrel & UNSP & 910903 \\
\hline 174625 & Oceanodroma furcata & Fork-tailed Storm-petrel & FTSP & 9109030201 \\
\hline 174628 & Oceanodroma leucorhoa & Leach's Storm-petrel & LESP & 9109030202 \\
\hline 174634 & Oceanodroma homochroa & Ashy Storm-petrel & ASSP & 9109030203 \\
\hline 174636 & Oceanodroma castro & Band-rumped Storm-petrel & BRSP & 9109030205 \\
\hline 174638 & Oceanodroma tethys & Wedge-rumped Storm-petrel & WRSP & 9109030206 \\
\hline 174640 & Oceanodroma melania & Black Storm-petrel & BLSP & 9109030207 \\
\hline 174641 & Oceanodroma tristrami & Tristram's Storm-petrel & TRSP & 9109030208 \\
\hline 174642 & Oceanodroma monorhis & Swinhoe's Storm-petrel & SSTP & 9109030209 \\
\hline 174646 & Oceanodroma microsoma & Least Storm-petrel & LTSP & 9109030301 \\
\hline
\end{tabular}


Appendix C. Continued.

\begin{tabular}{|c|c|c|c|c|}
\hline ITIS TSN & Scientific Name & Common name & NPPSD 4- & NODC Taxonomic Code \\
\hline 174650 & Oceanites oceanicus & Wilson's Storm-petrel & WISP & 9109030401 \\
\hline 174672 & Phaethon spp. & Unidentified Tropicbird & UNTR & 91100101 \\
\hline 174673 & Phaethon aethereus & Red-Billed Tropicbird & RBTR & 9110010101 \\
\hline 174676 & Phaethon lepturus & White-tailed Tropicbird & WTTR & 9110010102 \\
\hline 174679 & Phaethon rubricauda & Red-tailed Tropicbird & RTTR & 9110010103 \\
\hline 174684 & Pelecanus erythrorhynchos & American White Pelican & AWPE & 9110020101 \\
\hline 174685 & Pelecanus occidentalis & Brown Pelican & BRPE & 9110020102 \\
\hline 174697 & Sula spp. & Unidentified Booby & UNBO & 91100301 \\
\hline 174699 & Sula dactylatra & Masked Booby & MABO & 9110030101 \\
\hline 174704 & Sula leucogaster & Brown Booby & $\mathrm{BRBO}$ & 9110030103 \\
\hline 174707 & Sula sula & Red-Footed Booby & RFBO & 9110030104 \\
\hline 174712 & Morus bassanus & Northern Gannet & NOGA & 9110030107 \\
\hline 174714 & Phalacrocorax spp & Unidentified Cormorant & UNCO & 91100401 \\
\hline 174715 & Phalacrocorax carbo & Great Cormorant & GRCO & 9110040101 \\
\hline 174717 & Phalacrocorax auritus & Double-crested Cormorant & $\mathrm{DCCO}$ & 9110040102 \\
\hline 174724 & Phalacrocorax penicillatus & Brandt's Cormorant & $\mathrm{BRCO}$ & 9110040104 \\
\hline 174725 & Phalacrocorax pelagicus & Pelagic Cormorant & PECO & 9110040105 \\
\hline 174728 & Phalacrocorax urile & Red-faced Cormorant & RFCO & 9110040106 \\
\hline 174762 & Fregata spp. & Unidentified Frigatebird & UNFB & 91100601 \\
\hline 174766 & Fregata minor & Great Frigatebird & GRFB & 9110060102 \\
\hline 174769 & Fregata ariel & Lesser Frigatebird & LEFB & 9110060105 \\
\hline 174773 & Ardea herodias & Great Blue Heron & GTBH & 9111010101 \\
\hline 174793 & Butorides virescens & Green Heron & GRHE & 9111010201 \\
\hline 554135 & Ardea alba & Great Egret & GREG & 9111010601 \\
\hline 174813 & Egretta thula & Snowy Egret & SNEG & 9111010701 \\
\hline 174923 & Plegadis spp. & Unidentified Ibis & UNIB & 91110601 \\
\hline 174983 & Anatidae (Family) & Unidentified Duck, Goose, or Swan & UNWF & 911201 \\
\hline 174984 & Cygnus spp. & Unidentified Swan & SWAN & 91120101 \\
\hline 174985 & Cygnus Olor & Mute Swan & MUSW & 9112010101 \\
\hline 174987 & Cygnus columbianus & Tundra Swan & TUSW & 9112010202 \\
\hline 174992 & Cygnus buccinator & Trumpeter Swan & TRSW & 9112010203 \\
\hline 174999 & Branta canadensis & Canada Goose & CAGO & 9112010301 \\
\hline
\end{tabular}


Appendix C. Continued.

\begin{tabular}{|c|c|c|c|c|}
\hline ITIS TSN & Scientific name & Common name & $\begin{array}{l}\text { NPPSD 4- } \\
\text { Letter Code }\end{array}$ & NODC Taxonomic Code \\
\hline 714068 & Branta hutchinsii & Cackling Goose & CACG & 911201030109 \\
\hline 175011 & Branta bernicla & Brant & BRAN & 9112010302 \\
\hline 175042 & Chen canagica & Emperor Goose & EMGO & 9112010401 \\
\hline 175020 & Anser albifrons & Greater White-fronted Goose & GWFG & 9112010501 \\
\hline 175038 & Chen caerulescens & Snow Goose & SNGO & 9112010601 \\
\hline 175063 & Anas platyrhynchos & Mallard & MALL & 9112010901 \\
\hline 175068 & Anas rubripes & American Black Duck & AMBD & 9112010903 \\
\hline 175073 & Anas strepera & Gadwall & GADW & 9112010906 \\
\hline 175074 & Anas acuta & Northern Pintail & NOPI & 9112010907 \\
\hline 175081 & Anas crecca & Green-winged Teal & GWTE & 9112010910 \\
\hline 175086 & Anas discors & Blue-winged Teal & BWTE & 9112010912 \\
\hline 175093 & Anas querquedula & Garganey & GARG & 9112010915 \\
\hline 175094 & Anas americana & American Wigeon & AMWI & 9112010916 \\
\hline 175096 & Anas clypeata & Northern Shoveler & NOSH & 9112010917 \\
\hline 175122 & Aix sponsa & Wood Duck & WODU & 9112011001 \\
\hline 175124 & Aythya spp. & Unidentified Scaup & USCA & 91120111 \\
\hline 714011 & Anatinae (Subfamily) & Unidentified Duck & UNDU & 91120111 \\
\hline 175125 & Aythya americana & Redhead & REDH & 9112011101 \\
\hline 175129 & Aythya valisineria & Canvasback & CANV & 9112011105 \\
\hline 175130 & Aythya marila & Greater Scaup & GRSC & 9112011106 \\
\hline 175134 & Aythya affinis & Lesser Scaup & LESC & 9112011107 \\
\hline 175140 & Bucephala spp. & Unidentified Goldeneye & UNGO & 91120112 \\
\hline 175141 & Bucephala clangula & Common Goldeneye & COGO & 9112011201 \\
\hline 175144 & Bucephala islandica & Barrow's Goldeneye & BAGO & 9112011202 \\
\hline 175145 & Bucephala albeola & Bufflehead & BUFF & 9112011203 \\
\hline 175147 & Clangula hyemalis & Long-tailed Duck & LTDU & 9112011301 \\
\hline 175149 & Histrionicus histrionicus & Harlequin Duck & HADU & 9112011401 \\
\hline N/A & Somateria or Polysticta spp. & Unidentified Eider & UNEI & 91120116 \\
\hline 175153 & Polysticta stelleri & Steller's Eider & STEI & 9112011601 \\
\hline 175155 & Somateria mollissima & Common Eider & COEI & 9112011701 \\
\hline 175160 & Somateria spectabilis & King Eider & KIEI & 9112011702 \\
\hline 175161 & Somateria fischeri & Spectacled Eider & SPEI & 9112011703 \\
\hline
\end{tabular}


Appendix C. Continued.

\begin{tabular}{|c|c|c|c|c|}
\hline ITIS TSN & Scientific name & Common name & $\begin{array}{l}\text { NPPSD 4- } \\
\text { Letter Code }\end{array}$ & NODC Taxonomic Code \\
\hline 175162 & Melanitta spp. & Unidentified Scoter & UNSC & 91120118 \\
\hline 175163 & Melanitta fusca & White-winged Scoter & WWSC & 9112011802 \\
\hline 175170 & Melanitta perspicillata & Surf Scoter & SUSC & 9112011803 \\
\hline 175171 & Melanitta nigra & Black Scoter & BLSC & 9112011804 \\
\hline 175175 & Oxyura jamaicensis & Ruddy Duck & RUDU & 9112011901 \\
\hline 175183 & Lophodytes cucullatus & Hooded Merganser & HOME & 9112012001 \\
\hline 175184 & Mergus spp. & Unidentified Merganser & UNME & 91120121 \\
\hline 175185 & Mergus merganser & Common Merganser & COME & 9112012101 \\
\hline 175187 & Mergus serrator & Red-breasted Merganser & RBME & 9112012102 \\
\hline 175300 & Accipiter gentilis & Northern Goshawk & NOGO & 9113020501 \\
\hline 175304 & Accipiter striatus & Sharp-shinned Hawk & SSHA & 9113020502 \\
\hline 175350 & Buteo jamaicensis & Red-tailed Hawk & RTHA & 9113020601 \\
\hline 175407 & Aquila chrysaetos & Golden Eagle & GOEA & 9113020901 \\
\hline 175280 & Accipitridae spp. & Unidentified Eagle & UNEA & 91130210 \\
\hline 175420 & Haliaeetus leucocephalus & Bald Eagle & BAEA & 9113021002 \\
\hline 175423 & Haliaeetus pelagicus & Steller's Sea Eagle & STSE & 9113021003 \\
\hline 175430 & Circus cyaneus & Northern Harrier & NOHA & 9113021101 \\
\hline 175590 & Pandion haliaetus & Osprey & OSPR & 9113030101 \\
\hline 175598 & Falco spp. & Unidentified Falcon & UNFA & 91130402 \\
\hline 175599 & Falco rusticolus & Gyrfalcon & GYRF & 9113040201 \\
\hline 175604 & Falco peregrinus & Peregrine Falcon & PEFA & 9113040203 \\
\hline 175613 & Falco columbarius & Merlin & MERL & 9113040205 \\
\hline 176177 & Grus canadensis & Sandhill Crane & SACR & 9120010102 \\
\hline 176292 & Fulica americana & American Coot & AMCO & 9120040802 \\
\hline 176446 & Charadii (Suborder) & Unidentified Shorebird & UNSB & 9127 \\
\hline 176475 & Haematopus bachmani & Black Oystercatcher & BLOY & 9127030103 \\
\hline 176479 & Pluvialus or Charadrius spp. & Unidentified Plover & UNPL & 912704 \\
\hline 176506 & Charadrius semipalmatus & Semipalmated Plover & SEPL & 9127040202 \\
\hline 176510 & Charadrius alexandrinus & Snowy Plover & SNPL & 9127040204 \\
\hline 176514 & Charadrius mongolus & Mongolian Plover & MOPL & 9127040205 \\
\hline 176564 & Pluvialis dominica & American Golden Plover & AGPL & 912704110201 \\
\hline 554381 & Pluvialis fulva & Pacific Golden Plover & PAGP & 912704110202 \\
\hline
\end{tabular}


Appendix C. Continued.

\begin{tabular}{|c|c|c|c|c|}
\hline ITIS TSN & Scientific name & Common name & $\begin{array}{l}\text { NPPSD 4- } \\
\text { Letter Code }\end{array}$ & NODC Taxonomic Code \\
\hline 176567 & Pluvialis squatarola & Black-bellied Plover & BBPL & 9127041103 \\
\hline 553481 & Scolopacinae spp. & Unidentified Sandpiper & UNSA & 912705 \\
\hline 176569 & Arenaria spp. & Unidentified Turnstone & UNTU & 91270501 \\
\hline 176571 & Arenaria interpres & Ruddy Turnstone & RUTU & 9127050101 \\
\hline 176574 & Arenaria melanocephala & Black Turnstone & BLTU & 9127050102 \\
\hline 176586 & Capella gallinago & Common Snipe & COSN & 9127050401 \\
\hline 726048 & Gallinago delicata & Wilson's Snipe & WISN & 912705040103 \\
\hline 176593 & Numenius americanus & Long-billed Curlew & LBCU & 9127050601 \\
\hline 176599 & Numenius phaeopus & Whimbrel & WHIM & 9127050604 \\
\hline 176610 & Bartramia longicauda & Upland Sandpiper & UPSA & 9127050701 \\
\hline 176612 & Actitis macularia & Spotted Sandpiper & SPSA & 9127050801 \\
\hline 176614 & Tringa spp. & Unidentified Yellowlegs & YELL & 91270509 \\
\hline 176615 & Tringa solitaria & Solitary Sandpiper & SOSA & 9127050901 \\
\hline 176618 & Tringa glareola & Wood Sandpiper & WOSP & 9127050902 \\
\hline 176619 & Tringa melanoleuca & Greater Yellowlegs & GRYE & 9127050903 \\
\hline 176620 & Tring a flavipes & Lesser Yellowlegs & LEYE & 9127050904 \\
\hline 176635 & Heteroscelus incanus & Wandering Tattler & WATA & 9127051001 \\
\hline 176638 & Catoptrophorus semipalmatus & Willet & WILL & 9127051101 \\
\hline 176641 & Calidris spp. & Unidentified Stint & USTI & 91270512 \\
\hline 176642 & Calidris canutus & Red Knot & REKN & 9127051201 \\
\hline 176647 & Calidris ptilocnemis & Rock Sandpiper & ROSA & 9127051204 \\
\hline 176652 & Calidris acuminata & Sharp-tailed Sandpiper & STSA & 9127051205 \\
\hline 176653 & Calidris melanotos & Pectoral Sandpiper & PESA & 9127051206 \\
\hline 176654 & Calidris fuscicollis & White-rumped Sandpiper & WRSA & 9127051207 \\
\hline 176655 & Calidris bairdii & Baird's Sandpiper & BASP & 9127051208 \\
\hline 176656 & Calidris minutilla & Least Sandpiper & LESA & 9127051209 \\
\hline 176661 & Calidris alpina & Dunlin & DUNL & 9127051214 \\
\hline 176667 & Calidris pusilla & Semipalmated Sandpiper & SESA & 9127051216 \\
\hline 176668 & Calidris mauri & Western Sandpiper & WESA & 9127051217 \\
\hline 176669 & Calidris alba & Sanderling & SAND & 9127051218 \\
\hline 176673 & Aphriza virgata & Surfbird & SURF & 9127051301 \\
\hline 176674 & Limnodromus spp. & Unidentified Dowitcher & DOWI & 91270514 \\
\hline
\end{tabular}


Appendix C. Continued.

\begin{tabular}{|c|c|c|c|c|}
\hline ITIS TSN & Scientific name & Common name & $\begin{array}{l}\text { NPPSD 4- } \\
\text { Letter Code }\end{array}$ & NODC Taxonomic Code \\
\hline 176675 & Limnodromus griseus & Short-billed Dowitcher & SBDO & 9127051401 \\
\hline 176679 & Limnodromus scolopaceus & Long-billed Dowitcher & LBDO & 9127051402 \\
\hline 554145 & Calidris himantopus & Stilt Sandpiper & STIL & 9127051501 \\
\hline 176684 & Tryngites subruficollis & Buff-breasted Sandpiper & BBSP & 9127051601 \\
\hline 176685 & Limosa spp. & Unidentified Godwit & GODW & 91270517 \\
\hline 176686 & Limosa fedoa & Marbled Godwit & MAGO & 9127051701 \\
\hline 176687 & Limosa lapponica & Bar-tailed Godwit & BTGP & 9127051702 \\
\hline 176733 & Phalaropus spp. & Unidentified Phalarope & UNPH & 91270701 \\
\hline 554376 & Phalaropus fulicaria & Red Phalarope & REPH & 9127070101 \\
\hline 176735 & Phalaropus lobatus & Red-necked Phalarope & RNPH & 9127070301 \\
\hline 176791 & Stercorariidae (Family) & Unidentified Skua & UNSK & 91280101 \\
\hline 176792 & Stercorarius pomarinus & Pomarine Jaeger & POJA & 9128010101 \\
\hline 176793 & Stercorarius parasiticus & Parasitic Jaeger & PAJA & 9128010102 \\
\hline 176794 & Stercorarius longicaudus & Long-tailed Jaeger & LTJA & 9128010103 \\
\hline 176801 & Catharacta maccormicki & South Polar Skua & SPSK & 9128010202 \\
\hline 553473 & Larinae spp. & Unidentified Gull & UNGU & 91280201 \\
\hline 176808 & Larus hyperboreus & Glaucous Gull & GLGU & 9128020101 \\
\hline 176811 & Larus glaucoides & Iceland Gull & ICGU & 9128020102 \\
\hline 176814 & Larus glaucescens & Glaucous-winged Gull & GWGU & 9128020103 \\
\hline N.A. & N.A. & Glaucous-winged x Herring Gull & GHGU & $912802010399_{1}$ \\
\hline 176815 & Larus marinus & Great Black-backed Gull & GBGU & 9128020104 \\
\hline 176816 & Larus schistisagus & Slaty-backed Gull & SBGU & 9128020105 \\
\hline 176817 & Larus occidentalis & Western Gull & WEGU & 9128020106 \\
\hline N.A. & N.A. & Western x Glaucous-winged Gull & WGWG & $912802010699_{1}$ \\
\hline 176824 & Larus argentatus & Herring gull & HEGU & 9128020108 \\
\hline 176828 & Larus thayeri & Thayer's Gull & THGU & 9128020109 \\
\hline 176829 & Larus californicus & California Gull & CAGU & 9128020110 \\
\hline 176830 & Larus delawarensis & Ring-billed Gull & RBGU & 9128020111 \\
\hline 176831 & Larus crassirostris & Black-tailed Gull & BTGU & 9128020112 \\
\hline 176832 & Larus canus & Mew Gull & MEGU & 9128020113 \\
\hline 176835 & Larus ridibundus & Black-headed Gull & BHGU & 9128020114 \\
\hline 176837 & Larus atricilla Linnaeus & Laughing Gull & LAGU & 9128020115 \\
\hline
\end{tabular}


Appendix C. Continued.

\begin{tabular}{|c|c|c|c|c|}
\hline ITIS TSN & Scientific name & Common name & $\begin{array}{l}\text { NPPSD 4- } \\
\text { Letter Code }\end{array}$ & NODC Taxonomic Code \\
\hline 176838 & Larus pipixcan & Franklin's Gull & FRGU & 9128020116 \\
\hline 176839 & Larus philadelphia & Bonaparte's Gull & BOGU & 9128020117 \\
\hline 176841 & Larus heermanni & Heermann's Gull & HEEG & 9128020119 \\
\hline 176849 & Larus dominicanus & Kelp Gull & KEGU & 9128020128 \\
\hline 176851 & Pagophila eburnea & Ivory Gull & IVGU & 9128020201 \\
\hline 176806 & Rissa spp. & Unidentified Kittiwake & UNKI & 91280203 \\
\hline 176875 & Rissa tridactyla & Black-legged Kittiwake & BLKI & 9128020301 \\
\hline 176845 & Rissa brevirostris & Red-legged Kittiwake & RLKI & 9128020302 \\
\hline 176864 & Rhodostethia rosea & Ross's Gull & ROGU & 9128020401 \\
\hline 176866 & Xema sabini & Sabine's Gull & SAGU & 9128020501 \\
\hline 553483 & Sterninae spp. & Unidentified Tern & UNTE & 91280207 \\
\hline 176886 & Sterna trudeaui & Trudeau's Tern & TRTE & 9128020701 \\
\hline 176887 & Sterna forsteri & Forster's Tern & FOTE & 9128020702 \\
\hline 176888 & Sterna hirundo & Common Tern & COTE & 9128020703 \\
\hline 176890 & Sterna paradisaea & Arctic Tern & ARTE & 9128020704 \\
\hline 176893 & Sterna aleutica & Aleutian Tern & ALTE & 9128020706 \\
\hline 176894 & Sterna fuscata & Sooty Tern & SOTE & 9128020707 \\
\hline 176912 & Sterna lunata & Gray-backed Tern & GBTE & 9128020710 \\
\hline 176922 & Sterna maxima & Royal Tern & ROTE & 9128020728 \\
\hline 176923 & Sterna antillarum & Least Tern & LETE & 9128020729 \\
\hline 176924 & Sterna caspia & Caspian Tern & CATE & 9128020730 \\
\hline 176925 & Sterna elegans & Elegant Tern & ELTE & 9128020731 \\
\hline $\mathrm{N} / \mathrm{A}$ & Anous or Procelsterna spp. & Unidentified Noddy & UNNO & 91280211 \\
\hline 176941 & Anous stolidus & Brown Noddy & BRNO & 9128021101 \\
\hline 176944 & Anous minutus & Black Noddy & BLNO & 9128021102 \\
\hline 554390 & Procelsterna cerulea & Blue-gray Noddy & BGNO & 9128021501 \\
\hline 176954 & Gygis alba & White Tern & WHTE & 9128021601 \\
\hline 176959 & Chlidonias niger & Black Tern & BLTE & 9128021802 \\
\hline 176961 & Rynchops spp. & Unidentified Skimmer & SKIM & 91280301 \\
\hline 176967 & Alcidae (Family) & Unidentified Alcid & UNAL & 912901 \\
\hline 176973 & Uria spp. & Unidentified Murre & UNMU & 91290103 \\
\hline 176974 & Uria alge & Common Murre & COMU & 9129010301 \\
\hline
\end{tabular}


Appendix C. Continued.

\begin{tabular}{|c|c|c|c|c|}
\hline ITIS TSN & Scientific name & Common name & $\begin{array}{l}\text { NPPSD 4- } \\
\text { Letter Code }\end{array}$ & NODC Taxonomic Code \\
\hline 176978 & Uria lomvia & Thick-billed Murre & TBMU & 9129010302 \\
\hline 176982 & Alle alle & Dovekie & DOVE & 9129010401 \\
\hline 176984 & Cepphus spp. & Unidentified Guillemot & UNGI & 91290105 \\
\hline 176985 & Cepphus grylle & Black Guillemot & BLGU & 9129010501 \\
\hline 176991 & Cepphus columba & Pigeon Guillemot & PIGU & 9129010502 \\
\hline 176994 & Cepphus carbo & Spectacled Guillemot & SPGU & 9129010503 \\
\hline N.A. & Brachyramphus or Synthliboramphus spp. & Unidentified Murrelet & UNML & $9129010599_{1}$ \\
\hline 176995 & Brachyramphus spp. & Brachyramphus Murrelet & BRMU & 91290106 \\
\hline 176996 & Brachyramphus marmoratus & Marbled Murrelet & MAMU & 9129010601 \\
\hline 176998 & Brachyramphus brevirostris & Kittlitz's Murrelet & KIMU & 9129010602 \\
\hline 554143 & Brachyramphus perdix & Long-billed Murrelet & LBMU & $9129010699_{1}$ \\
\hline 177006 & Synthliboramphus spp. & Synthliboramphus Murrelet & SYMU & 91290108 \\
\hline 177008 & Synthliboramphus antiquus & Ancient Murrelet & ANMU & 9129010801 \\
\hline 177009 & Synthliboramphus wumizusume & Japanese Murrelet & JAMU & 9129010802 \\
\hline 177010 & Synthliboramphus craveri & Craveri's Murrelet & CRMU & 9129010803 \\
\hline 177011 & Synthliboramphus hypoleucus & Xantus's Murrelet & XAMU & 9129010804 \\
\hline $\mathrm{N} / \mathrm{A}$ & Aethia or Ptychoramphus spp. & Unidentified Auklet & UNAU & $9129010899_{1}$ \\
\hline 177013 & Ptychoramphus aleuticus & Cassin's Auklet & CAAU & 9129010901 \\
\hline 554029 & Aethia psittacula & Parakeet Auklet & PAAU & 9129011001 \\
\hline 177019 & Aethia cristatella & Crested Auklet & CRAU & 9129011101 \\
\hline 177020 & Aethia pusilla & Least Auklet & LEAU & 9129011102 \\
\hline 177021 & Aethia pygmaea & Whiskered Auklet & WHAU & 9129011103 \\
\hline 177023 & Cerorhinca monocerata & Rhinoceros Auklet & RHAU & 9129011201 \\
\hline 177024 & Fratercula spp. & Unidentified Puffin & UNPU & 91290113 \\
\hline 177029 & Fratercula corniculata & Horned Puffin & HOPU & 9129011302 \\
\hline 177032 & Fratercula cirrhata & Tufted Puffin & TUPU & 9129011401 \\
\hline 177935 & Asio flammeus & Short-eared Owl & SEOW & 9137020902 \\
\hline 178106 & Megaceryle alcyon & Belted Kingfisher & BEKI & 9147010101 \\
\hline 178536 & Cinclus mexicanus & American Dipper & AMDI & 9158110101 \\
\hline 179665 & Corvidae (Family) & Crow, Raven, Magpie & CORV & 915845 \\
\hline
\end{tabular}

1 NODC Taxonomic Codes for previously unrecognized taxa were generated to ensure correct phylogenetic order. 


\section{Appendix D. Marine Mammal Species from the North Pacific Pelagic Seabird Database (NPPSD) Taxonomic Code List 2.1}

The following table includes the National Oceanographic Data Center (NODC) Taxonomic Code list useful for sorting, as well as the more current Integrated Taxonomic Information (ITIS) Taxonomic Serial Number (TSN).

\begin{tabular}{|c|c|c|c|c|}
\hline ITIS TSN & Scientific name & Common name & $\begin{array}{l}\text { NPPSD 4- } \\
\text { Letter Code }\end{array}$ & NODC Taxonomic Code \\
\hline 179913 & Mammalia (Class) & Unidentified Marine Mammal & UNMM & 92 \\
\hline 180403 & Cetacea (Order) & Unidentified Whale & UNWH & 9217 \\
\hline 180415 & Unidentified Delphinidae & Unidentified Dolphin & UNDO & 921802 \\
\hline 180426 & Tursiops truncatus & Bottlenose Dolphin & BNDO & 9218020401 \\
\hline 180429 & Stenella longirostris & Spinner Dolphin & SPDO & 9218020501 \\
\hline 180434 & Stenella coeruleoalba & Striped Dolphin & STDO & 9218020504 \\
\hline 180438 & Delphinus delphis & Common Dolphin & CODO & 9218020601 \\
\hline 555654 & Delphinus capensis & Long-beaked Common Dolphin & LBCD & $921802060199^{1}$ \\
\hline 180444 & Lagenorhynchus obliquidens & Pacific White-sided Dolphin & PWSD & 9218020803 \\
\hline 180454 & Lissodelphis borealis & Northern Right Whale Dolphin & NRWD & 9218021001 \\
\hline 180457 & Grampus griseus & Risso's Dolphin & RIDO & 9218021101 \\
\hline 180463 & Pseudorca crassidens & False Killer Whale & FKWH & 9218021401 \\
\hline 180466 & Globicephala macrorhynchus & Short-finned Pilot Whale & SFPW & 9218021502 \\
\hline 180469 & Orcinus orca & Killer Whale & KIWH & 9218021601 \\
\hline 180473 & Phocoena phocoena & Harbor Porpoise & HAPO & 9218021801 \\
\hline 180480 & Phocoenoides dalli & Dall's Porpoise & DAPO & 9218022001 \\
\hline 180483 & Delphinapterus leucas & Beluga Whale & BEWH & 9218030101 \\
\hline 180489 & Physeter macrocephalus & Sperm Whale & SPWH & 9218040102 \\
\hline 180491 & Kogia breviceps & Pygmy Sperm Whale & PSWH & 9218040201 \\
\hline 180506 & Mesoplodon spp. & Unidentified Beaked Whale & UBKW & 921805 \\
\hline 180496 & Berardius bairdii & Baird's Beaked Whale & BKWH & 9218050102 \\
\hline 180498 & Ziphius cavirostris & Cuvier's Beaked Whale & GBWH & 9218050201 \\
\hline 552298 & Mysticeti (Suborder) & Unidentified Baleen Whale & UNBW & 9219 \\
\hline 180521 & Eschrichtius robustus & Gray Whale & GRWH & 9219010101 \\
\hline 180524 & Balaenoptera acutorostrata & Minke Whale & MIWH & 9219020101 \\
\hline
\end{tabular}


Appendix D. Continued.

\begin{tabular}{|c|c|c|c|c|}
\hline ITIS TSN & Scientific name & Common name & NPPSD 4-Letter Code & NODC Taxonomic Code \\
\hline 180526 & Balaenoptera borealis & Sei Whale & SEWH & 9219020103 \\
\hline 180527 & Balaenoptera physalus & Fin Whale & FIWH & 9219020104 \\
\hline 180528 & Balaenoptera musculus & Blue Whale & BLWH & 9219020105 \\
\hline 180530 & Megaptera novaeangliae & Humpback Whale & HBWH & 9219020201 \\
\hline 180533 & Balaena mysticetus & Bowhead Whale & BOWH & 9219030102 \\
\hline 180537 & Eubalaena japonica & Right Whale & RIWH & 9219030301 \\
\hline 180542 & Ursus maritimus & Polar Bear & POBE & 9220010101 \\
\hline 180547 & Enhydra lutris & Sea Otter & SEOT & 9220020101 \\
\hline 552326 & Lutrinae (Subfamily) & Unidentified Otter & UNOT & $9220020199^{1}$ \\
\hline 180549 & Lontra canadensis & River Otter & RIOT & 9220020201 \\
\hline 552303 & Caniformia (Suborder) & Unidentified Pinniped & UNPI & 9221 \\
\hline 180621 & Zalophus californianus & California Sea Lion & CASL & 9221010301 \\
\hline 180625 & Eumetopias jubatus & Steller Sea Lion & STSL & 9221010501 \\
\hline 180627 & Callorhinus ursinus & Northern Fur Seal & NOFS & 9221010601 \\
\hline 180639 & Odobenus rosmarus & Walrus & WALR & 9221020101 \\
\hline 180640 & Phocidae (Family) & Unidentified Seal & UNSE & 922103 \\
\hline 180642 & Phoca largha & Spotted Seal & SPSE & 9221030101 \\
\hline 622018 & Pusa hispida & Ringed Seal & RISE & 9221030102 \\
\hline 622021 & Histriophoca fasciata & Ribbon Seal & RBSE & 9221030106 \\
\hline 180649 & Phoca vitulina & Harbor Seal & HASE & 9221030107 \\
\hline 180655 & Erignathus barbatus & Bearded Seal & BESE & 9221030301 \\
\hline 180672 & Mirounga angustirostris & Northern Elephant Seal & NESE & 9221031002 \\
\hline
\end{tabular}

${ }^{1}$ NODC Taxonomic Codes for previously unrecognized taxa were generated to ensure correct phylogenetic order. 


\section{Appendix E. North Pacific Pelagic Seabird Database, Version 2 Query Tool}

\section{Purpose of Query Form}

Although the data in the NPPSD v. 2.0 may be accessed directly by opening the NPPSD_Back.mdb file, we created a graphical filter and export tool hereafter referred to as the "Query Form", for the database in an effort to make the extraction of data as accurate and uniform as possible (fig. E1). This form provides an intuitive interface to assist users in selecting specific data from the larger NPPSD v. 2.0 dataset and exporting cross-tabulated summaries of these data. This tool is available with the NPPSD database on the NPPSD web site. We successfully tested the Query Form for accuracy on numerous filter combinations; however, we could not test all possible combinations. If users encounter any problems with the tool, please report using contact information available on the NPPSD web page at the USGS Alaska Science Center Website http://alaska.usgs.gov/.

\section{Setup}

The Query Form requires Microsoft Access 2003 or later. Note, for Access 2007 or later when the Query Form is first started, a yellow dialog box will appear beneath the "Ribbon" at the top of the page. You must click on "enable" to run the script that looks for the database. There is no installation; however the first time the Query Form is used, a dialog box indicate that it cannot locate the "back-end" (NPPSD database), and will ask for its location, select OK and a dialog box will appear. Either type or browse to the location of the NPPSD database file. Once the location is entered in the dialog box select refresh links. A new dialog box will appear to indicate if the linking was successful. Select OK and the Query Form should appear.

\section{Query Form Menu}

The Query Form menu has six panels: (1) Records, (2) Filter Records, (3) Sort Records, (4) Hide/Show Columns, (5) Other Options, and (6) Export (fig. E1). When the Query Form opens it loads a subset of the data to the Records panel. This subset of records provides users with series of populated fields from the linked location and observation tables to assist with the selection of filters. The text boxes and check boxes throughout the form will be blank. Unless an entry is made no filter or action, e.g. sorting, will occur. Descriptions of the individual query form panels are given below.

\section{Records Panel}

The Records panel will look familiar to most users. Fields are listed across the top of the panel. Each record is displayed as a row. Users can scroll through this panel as they would any database table or spreadsheet. As previously mentioned above, when first loaded, the Query Form selects a subset of the data, i.e. Aleutian Tern (ALTE) for the Species. This panel can be very helpful in understanding the dataset in general as well as specific selections. 


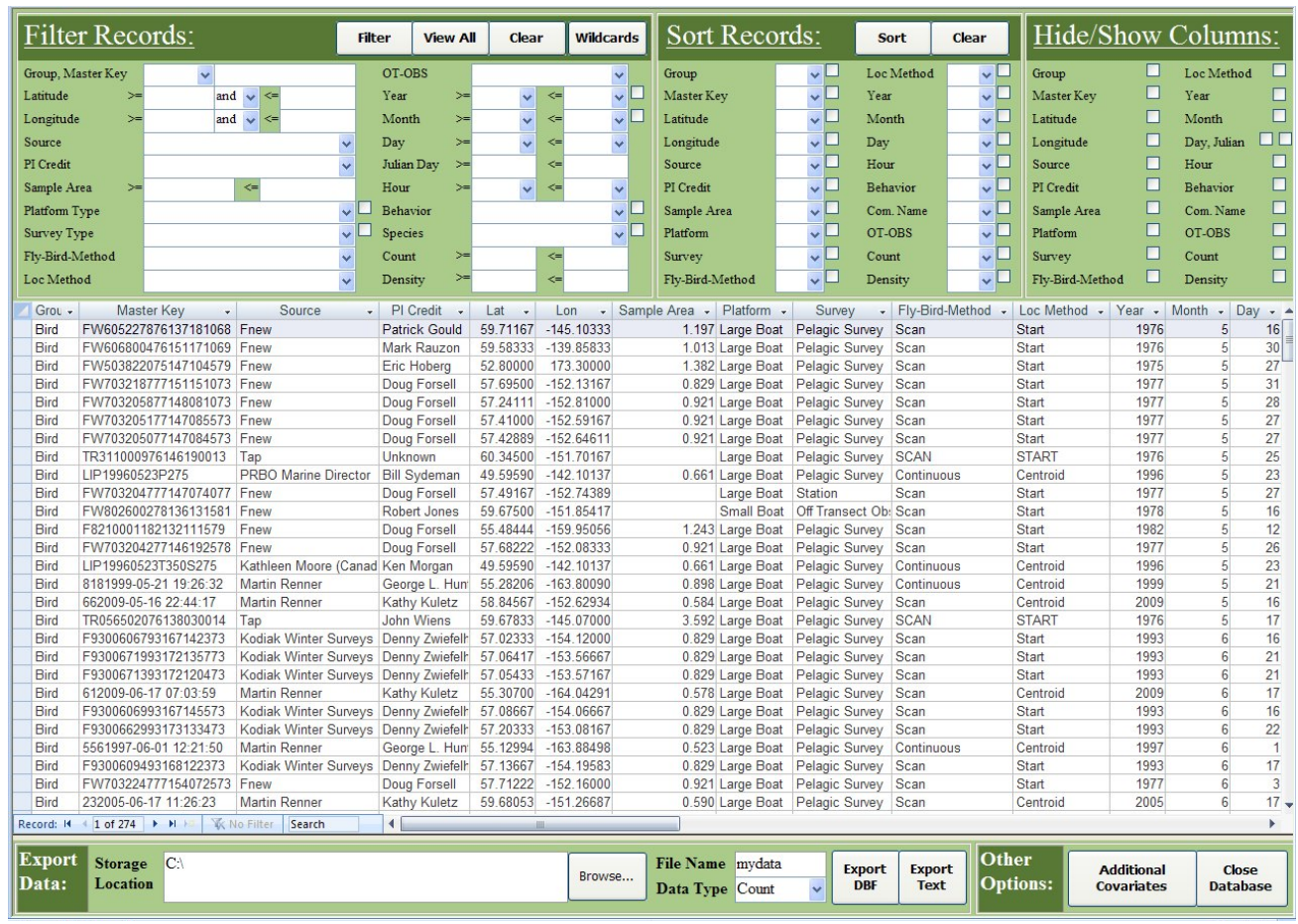

Figure E1. The NPPSD v2.0 "Front End" query form for selecting variable filters and export type and location for marine birds and mammals.

\section{Filter Records Panel}

The Filter Selection panel allows users to select the specific subsets for most fields. Boxes following field names are by default blank (fig. E1). Users may enter field values in these boxes or select values with pull-down menus. These menus are associated with lookup tables providing users with the available values in the database (fig. E2). Fields capable of multiple selections will have a check-box following the text box (fig. E3). To make multiple selections from a field, e.g., both "Flying" and "Water" in the Behavior field, check the box and a window will open allowing users to make multiple selections. Once checked, a pop-up window will be displayed. Users select the variables desired and then select the close button. The pop-up window for species includes information on the total count for each species. This may help end-users identify species that are so rare that the NPPSD may not provide the data necessary for numeric analysis (fig. E4). Once all filters are selected the filter button should be selected and the records meeting the selected criteria will be displayed in the Records panel. In addition to the filter button at the top of the Filter Records panel there are three additional buttons "View All", "Clear", and "Wildcards". The View All button removes current filters and displays all observations and associated location data. The Clear button must be used to remove current filters prior to making a new selection. The Wildcard button opens up a pop-up window listing wildcard characters and their use. 


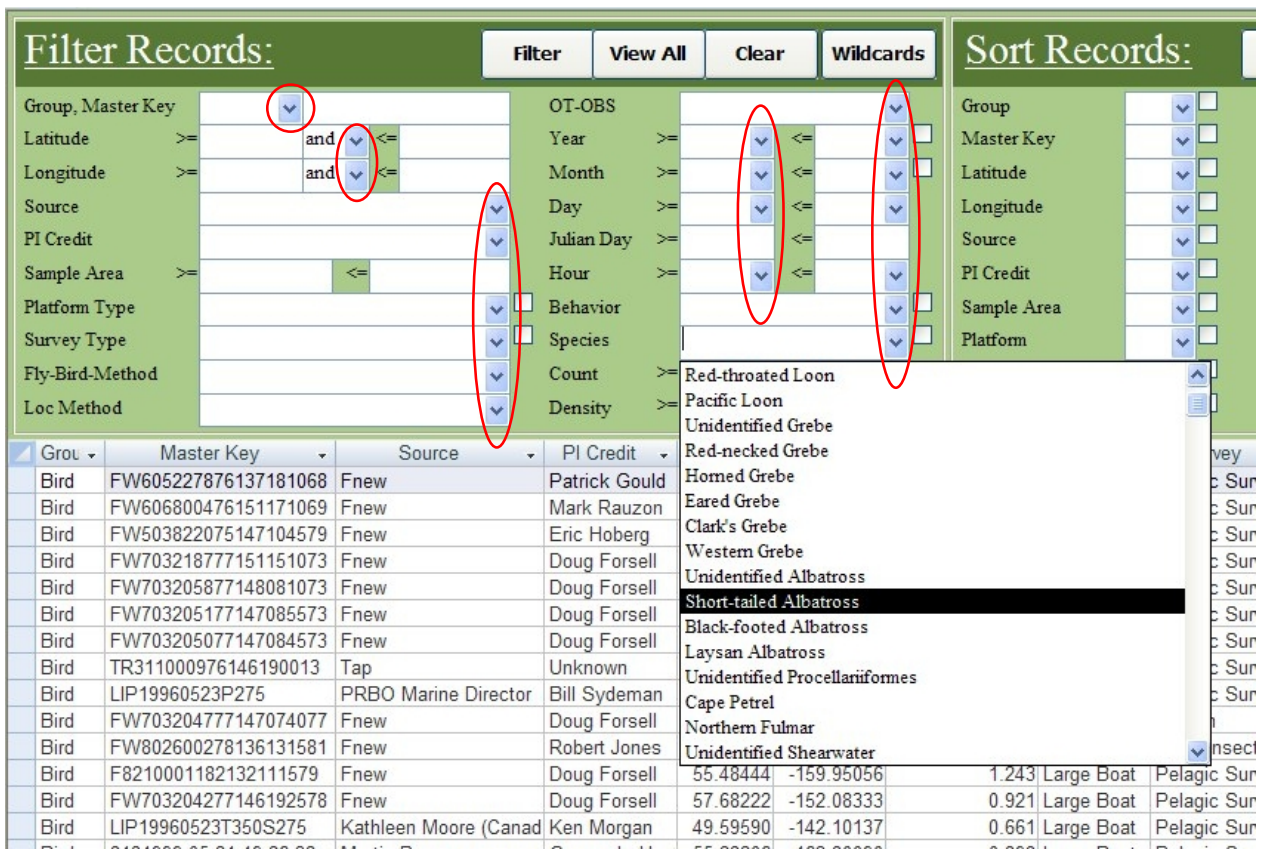

Figure E2. Filter selection panel of the NPPSD v2.0 "Front End." The red ovals indicate drop down controls. Clicking on any drop down control will open an associated lookup table. Once open, a single selection can be made by clicking on any item in the drop down menu.

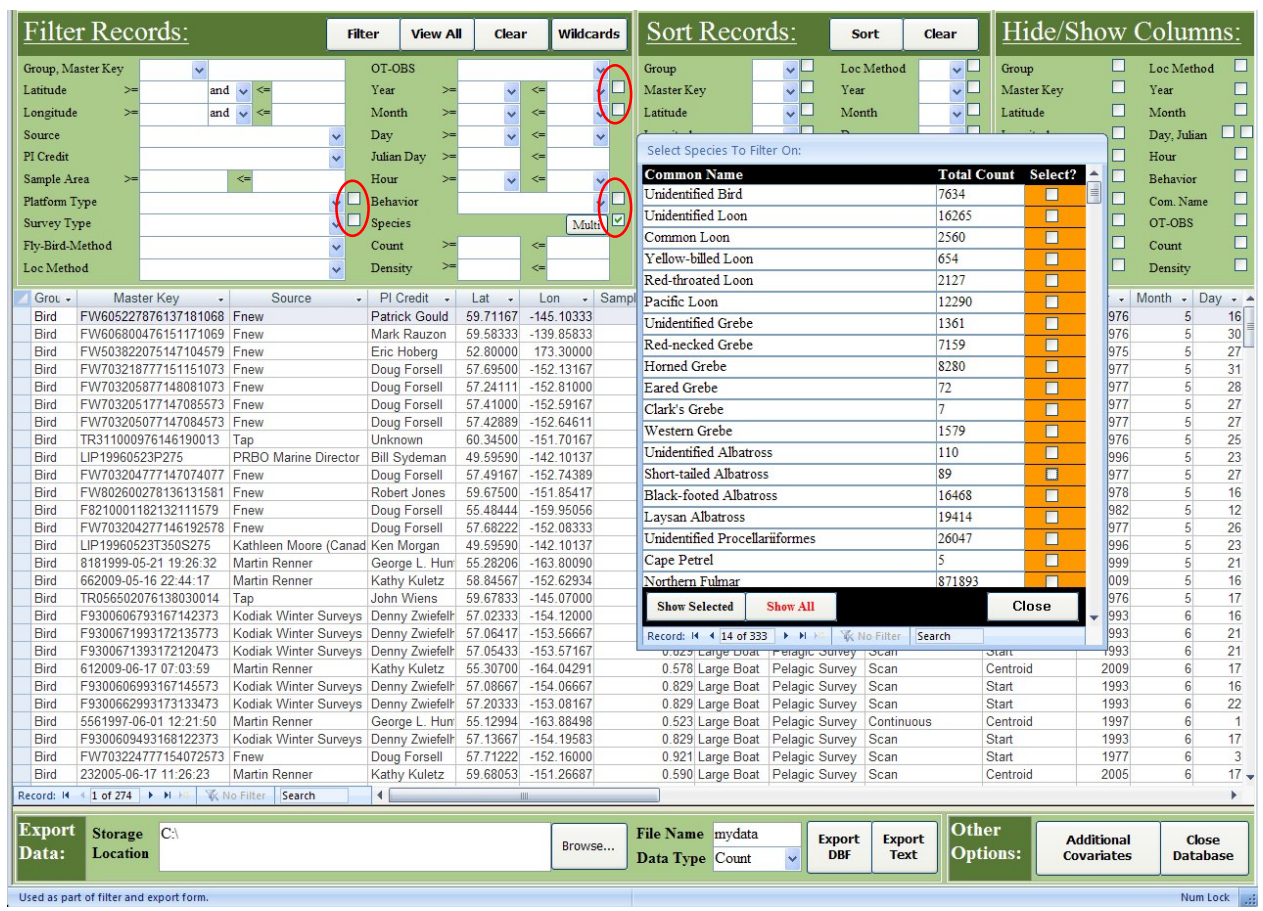

Figure E3. Some variables in the Filter selection panel of the NPPSD v2.0 have check-boxes next to them (red ovals). Selecting on one of the boxes will open a multiple selection window. This window allows users to select multiple items. 


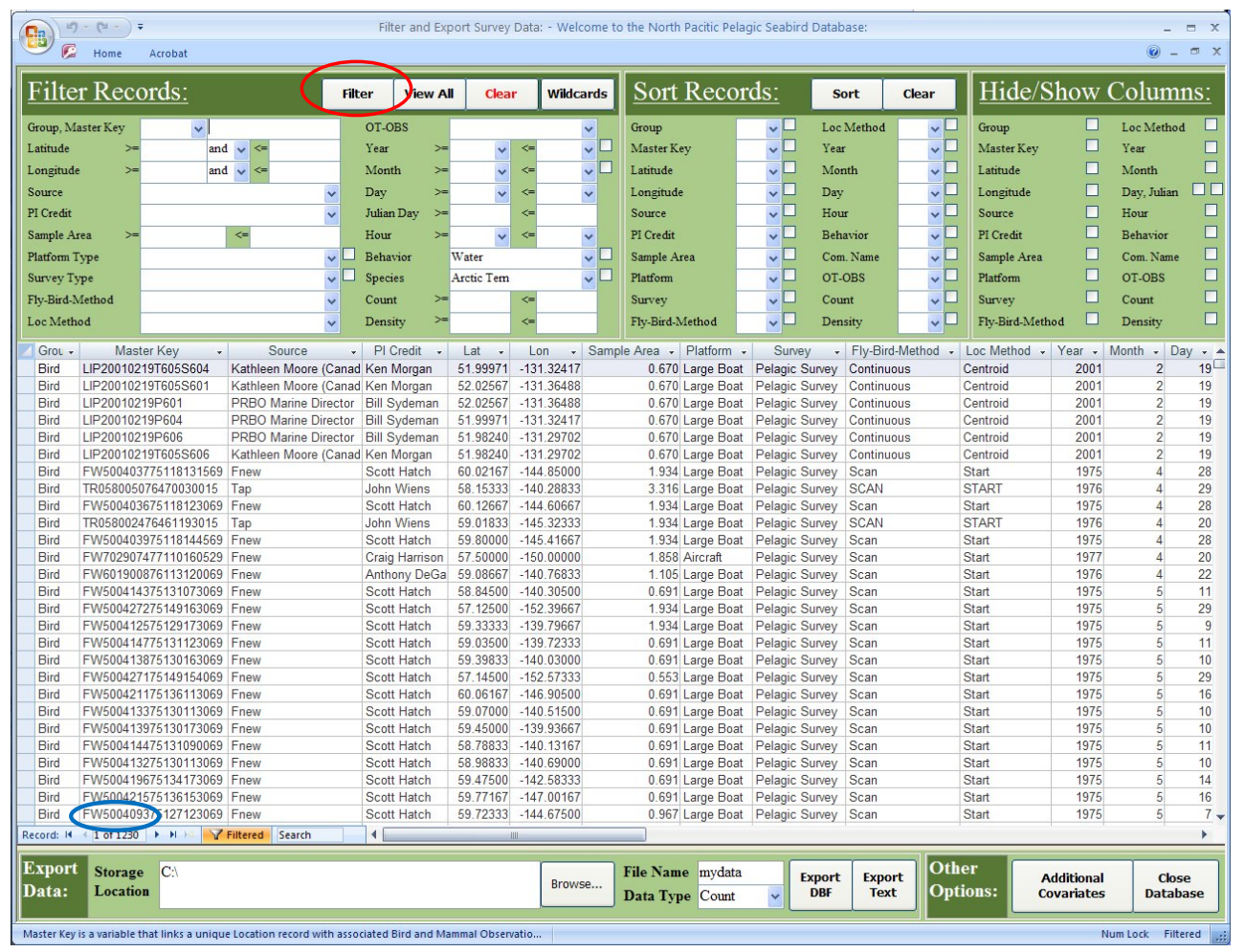

Figure E4. Once selections are made the Filter button (red oval) is clicked and the selected records will be displayed. The number of records matching the filtered fields is found in the bottom left of the record display window (blue oval).

\section{Sort Records Panel}

The Sort Records panel lists 20 of the fields from the location and observations tables. To sort on a field, users must select the check-box next to the field and then use the associated drop down menu to select the sort order (fig. E5). For a single field select one, for multiple fields assign the sort order accordingly. All sorts are from low to high.

\section{Hide/Show Columns Panel}

The Records Panel contains much more information than can be displayed in the available space. To assist users in displaying only the necessary fields we included the "Hide/Show Columns." This panel provides a set of check-boxes that will hide all checked fields (fig. E5). Clicking on a check-box selects a field and it will not be displayed in the Records Panel. Clicking on the box a second time will remove the check and the field will be displayed again. Changes are only made to the Records Panel display; hidden fields will not affect output. 


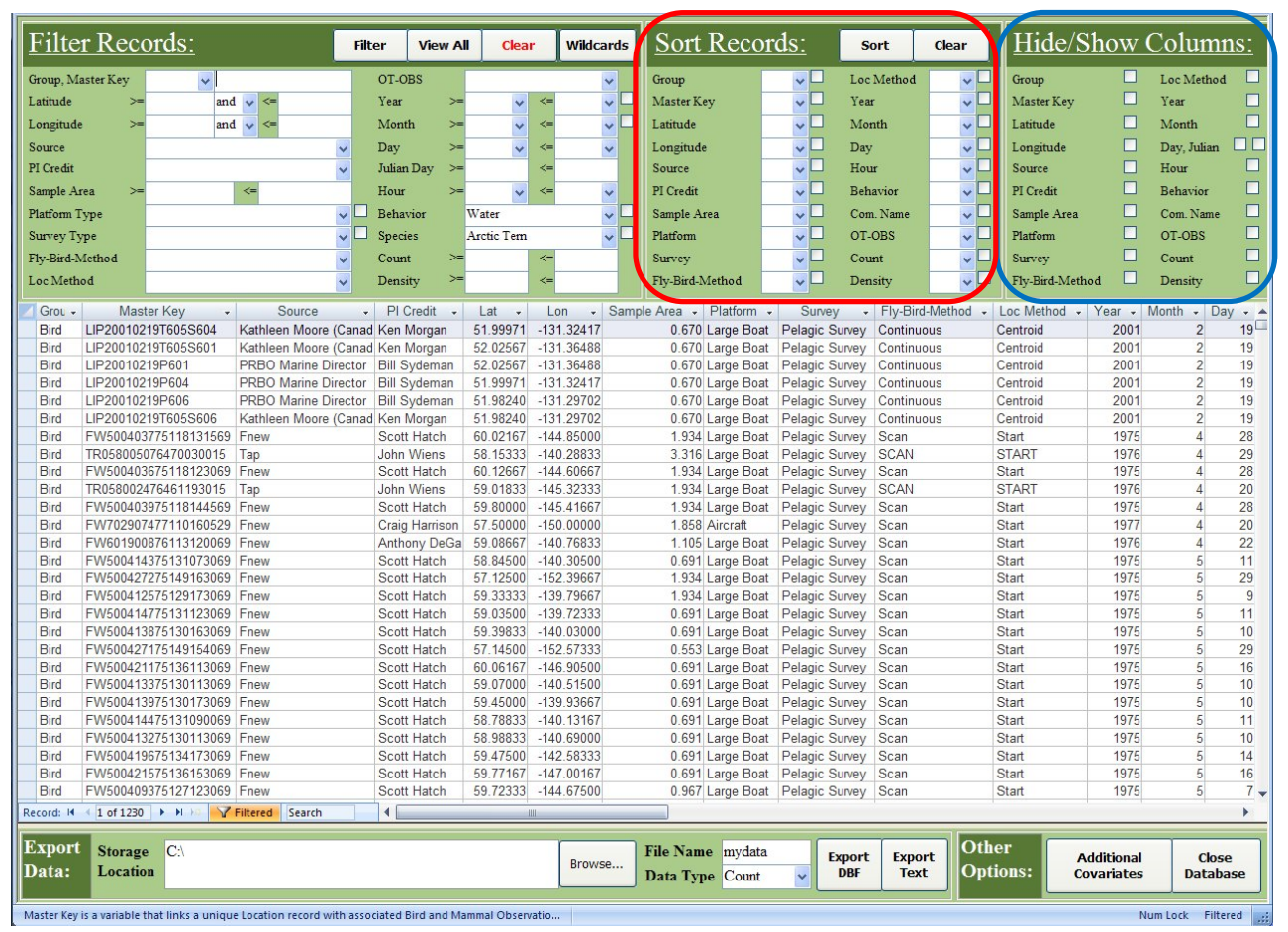

Figure E5. Location of the "Sort Records" pane (red square) and "Hide/Show Columns" pane (blue square) Hide/Show Columns Panel

\section{Other Options Panel}

The Other Options panel will open a pair of pop-up windows. The first informs users that selected fields will be added to the output. The second is a check-box with the available fields (fig. E6). For all but the "Behavior" field these variables are not typically included in cross-tabulated output because of the large number ( $>50 \%$ ) of missing values. The Behavior field is unique in that it affects the cross-tabulation by summarizing observations by behavior. If this field is not selected, behaviors selected using the Filter Records panels are summarized together; the behavior field is filtered but not included as a group.

\section{Export Panel}

The Export Panel provides users with a combination of text-boxes and buttons to select the location and type of table exported (fig. E7). The left portion of the panel is dedicated to a textbox/browse button used to determine the destination for the export, the $\mathrm{C}: \backslash$ drive is the default. Next to the storage location text-box there is a text box for the file name and beneath it the data type drop-down box. Users can select either "Count" or "Density". Note, if Density is selected only records that have an associated sample area will be output. In effect selecting density acts as a de facto filter. Once location, file name and data type are selected users should select either the "Export DBF" or "Export Text". Selecting the Export DBF button will run a cross-tabulation query using the entire user selected criteria and make a dBase (.dbf) file. Selecting the Export Text button will run a cross-tabulation query using all of the user selected criteria and make a comma delimited ASCII text (.csv) file. 


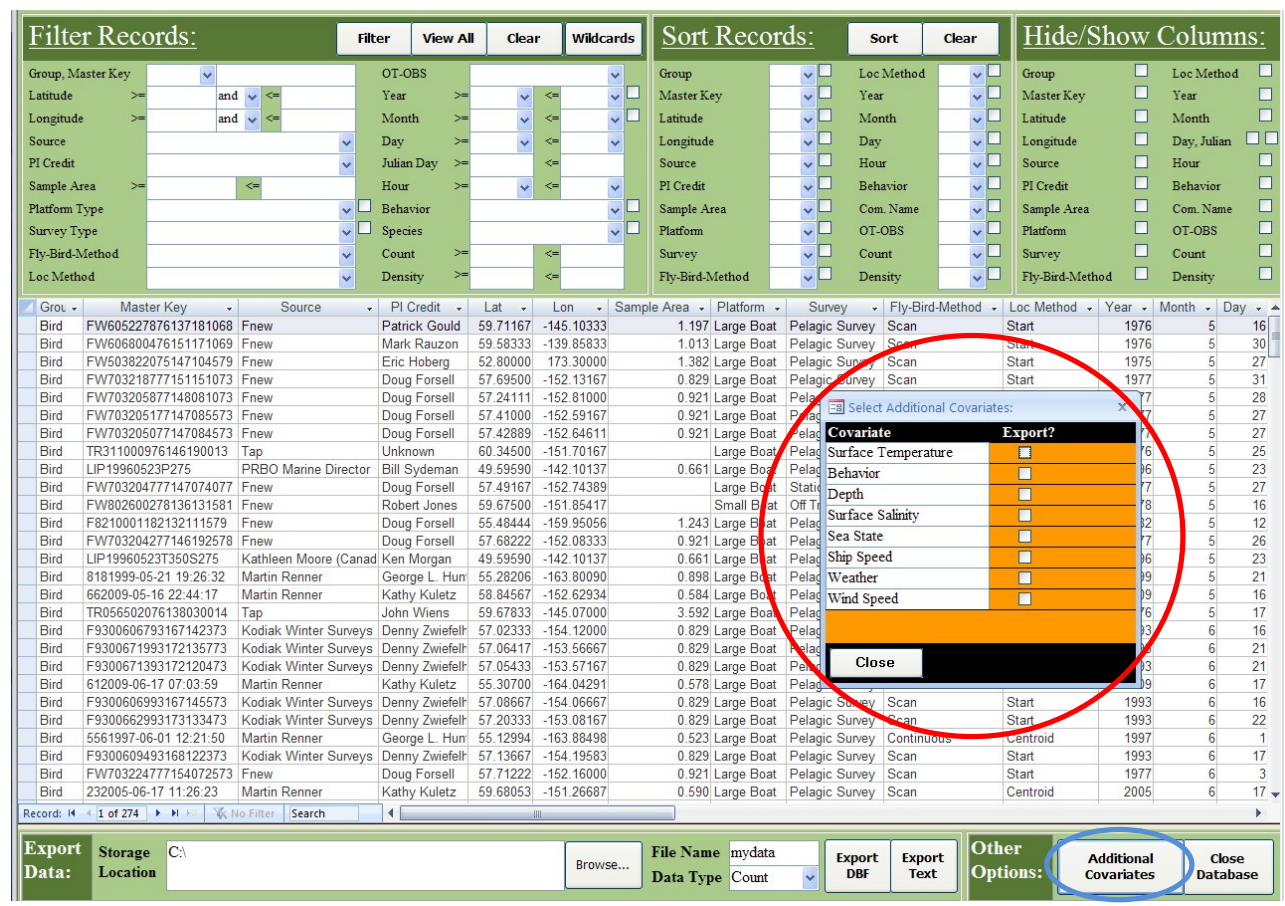

Figure E6. Selecting the "Additional Covariates" button (blue circle) will open a multiple selection window (red circle). Checking a box adds that variable to the cross-tabulation output.

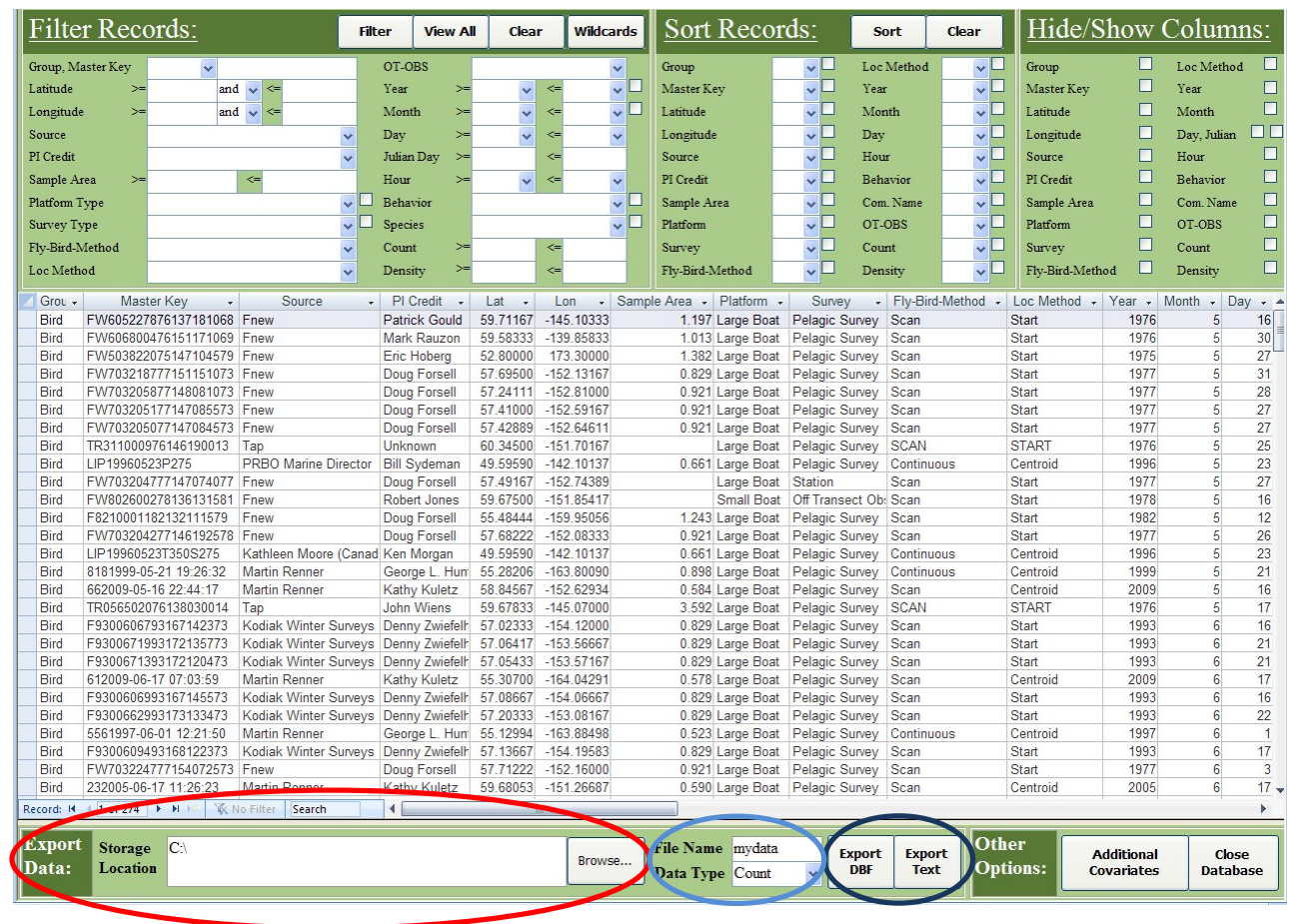

Figure E7. The export panel consists of a text boxes/browse button for the location for the exported file (red circle), a text box and pull-down menu for file name and data type (light-blue circle), and buttons for selecting a database (dbf) or comma delimited (csv) file (dark-blue circle). 


\section{Data Output}

Output from the Data Query Form can be written to either dbf or csv formats. Regardless of format the outputted field names are consistent with the NPPSD database fields (fig. E8). One product of the cross-tabulation is a null field (assigned as " $\mathrm{X}_{-}$" in the dbf output or " $<$" in the csv output) immediately prior to filter selected species. This field is a result of the cross-tabulation and can be deleted or ignored. Species are presented as one or more columns depending on the selection filter. In the csv output the species are identified with the "Common Name", in the dbf output they are identified with "4-letter NPPSD Code". The 4-letter codes are necessary in the dbf output due to field name length restrictions of this format. Note the csv output currently includes quotes around field names and values. This is a product of the export query and cannot currently be changed. Users can either strip the text delimiters or change data types in their software. Users of spreadsheet software should be aware of the limitations of specific programs. A cross-tabulation of the entire NPPSD v.2 has more rows and more columns than many spreadsheets can load, e.g. Excel 2003. Care should be taken to assure no data is truncated.

\begin{tabular}{|c|c|c|c|c|c|c|c|c|c|c|c|c|c|c|c|c|}
\hline \multicolumn{16}{|c|}{ 짐 COMUALL.DBF } & $-a x$ \\
\hline 1 & A & B & c & D & E & $\mathrm{F}$ & G & H & 1 & J & $\mathrm{k}$ & L & M & & $\mathrm{N}$ & 0 \\
\hline 10 & MASTER KEY & IPI_CREDIT & SAREA & LATITUDE & LONGITUDE & PLATFORM & SURVEY & FLY_BIRD_M & LOC_METHOD & YEAR & MONTH DA & & JULIAN & DAYX & & COMU \\
\hline 217 & 00008921689285183669 & Denny Zwiefelhofer & 1.10520 & 58.68500 & -152.26500 & Large Boat & Pelagic Survey & Scan & Start & 1989 & 10 & 12 & & 285 & 0.00000 & 0.00000 \\
\hline 218 & 00008921789285184669 & Denny Zwiefelhofer & 1.01310 & 58.66667 & -152.21333 & Large Boat & Pelagic Survey & Scan & Start & 1989 & 10 & 12 & & 285 & 0.00000 & 0.00000 \\
\hline 219 & 00008921889286101669 & Denny Zwiefelhofer & 1.01310 & 58.38667 & -151.41333 & Large Boat & Pelagic Survey & Scan & Start & 1989 & 10 & 13 & & 286 & 0.00000 & 0.00000 \\
\hline 220 & 00008921989286102669 & Denny Zwiefelhofer & 1.10520 & 58.40500 & -151.46500 & Large Boat & Pelagic Survey & Scan & Start & 1989 & 10 & 13 & & 286 & 0.00000 & 0.00000 \\
\hline 221 & 00008922089286103669 & Denny Zwiefelhofer & 1.01310 & 58.42167 & -151.51500 & Large Boat & Pelagic Survey & Scan & Start & 1989 & 10 & 13 & & 286 & 0.00000 & 0.00000 \\
\hline 222 & 00008922189286104669 & Denny Zwiefelhofer & 1.01310 & 58.43667 & -151.56500 & Large Boat & Pelagic Survey & Scan & Start & 1989 & 10 & 13 & & 286 & 0.00000 & 0.00000 \\
\hline 223 & 00008922289286105669 & Denny Zwiefelhofer & 1.01310 & 58.45333 & -151.61333 & Large Boat & Pelagic Survey & Scan & Start & 1989 & 10 & 13 & & 286 & 0.00000 & 0.00000 \\
\hline 224 & 00008922389286110669 & Denny Zwiefelhofer & 1.01310 & 58.46667 & -151.66500 & Large Boat & Pelagic Survey & Scan & Start & 1989 & 10 & 13 & & 286 & 0.00000 & 00000 \\
\hline 225 & 00008922489286111669 & Denny Zwiefelhofer & 1.10520 & 8.48500 & -151.71500 & Large Boat & Pelagic Survey & Scan & Start & 1989 & 10 & 13 & & 286 & 0.00000 & 0.00000 \\
\hline 226 & 00008922589286112669 & Denny Zwiefelhofer & 1.10520 & 58.50167 & -151.76500 & Large Boat & Pelagic Survey & Scan & Start & 1989 & 10 & 13 & & 286 & 0.00000 & 5.42900 \\
\hline 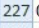 & 00008922689286113669 & Denny Zwiefelhofer & 1.01310 & 58.52167 & -151.81333 & Large Boat & Pelagic Survey & Scan & Start & 1989 & 10 & 13 & & 286 & 0.00000 & 0.00000 \\
\hline 228 & 00008922789286114669 & Denny Zwiefelhofer & 1.01310 & 58.54167 & -151.86167 & Large Boat & Pelagic Survey & Scan & Start & 1989 & 10 & 13 & & 286 & 0.00000 & 0.00000 \\
\hline 229 & 00008922889286115669 & Denny Zwiefelhofer & 1.10520 & 58.56000 & -151.91000 & Large Boat & Pelagic Survey & Scan & Start & 1989 & 10 & 13 & & 286 & 0.00000 & 0.00000 \\
\hline 230 & 00008922989286120669 & Denny Zwiefelhofer & 1.10520 & 58.58000 & -151.96000 & Large Boat & Pelagic Survey & Scan & Start & 1989 & 10 & 13 & & 286 & 0.00000 & 0.00000 \\
\hline 231 & 00008923089286121669 & Denny Zwiefelhofer & 1.10520 & 58.59833 & -152.01333 & Large Boat & Pelagic Survey & Scan & Start & 1989 & 10 & 13 & & 286 & 0.00000 & 0.00000 \\
\hline 232 & 00008923189286122669 & Denny Zwiefelhofer & 1.10520 & 58.61667 & -152.06500 & Large Boat & Pelagic Survey & Scan & Start & 1989 & 10 & 13 & & 2 & 0.00000 & .00000 \\
\hline 233 & 00008923289286123669 & Denny Zwiefelhofer & 19730 & 58.63500 & -152.11667 & Large Boat & Pelagic Survey & Scan & Start & 1989 & 10 & 13 & & 286 & 0.00000 & 0.00000 \\
\hline 234 & 1001986-08-13 01:23:12 & George L. Hunt & 0.89862 & 64.26095 & -171.78704 & Large Boat & Pelagic Survey & Continuous & Centroid & 1986 & 8 & 13 & & 225 & 0.00000 & 0.00000 \\
\hline 235 & 1001986-08-13 01:50:56 & George L. Hunt & 0.29848 & 64.25093 & -171.76437 & Large Boat & Pelagic Survey & Continuous & Centroid & 1986 & 8 & 13 & & 225 & 0.00000 & 0.00000 \\
\hline 236 & 1011986-08-13 02:38:06 & George L. Hunt & 0.89947 & 64.29192 & -171.66511 & Large Boat & Pelagic Survey & Continuous & Centroid & 1986 & 8 & 13 & & 225 & 0.00000 & 2.22400 \\
\hline 237 & 1011986-08-13 02:47:54 & George L. Hunt & 0.89361 & 64.27143 & -171.62464 & Large Boat & Pelagic Survey & Continuous & Centroid & 1986 & 8 & 13 & & 225 & 0.00000 & 0.00000 \\
\hline 238 & 1011986-08-13 02:57:42 & George L. Hunt & 9389 & 64.25087 & -171 & Large Boat & Pelagic Survey & Contin & Cent & 36 & 8 & 13 & & 225 & 0.00000 & 0 \\
\hline 239 & 1011986-08-13 03:07:32 & George L. Hunt & 0.89110 & 64.23027 & -17 & Large Boat & Pelagic Survey & Continuous & Centroid & 1986 & 8 & 13 & & 225 & 0.00000 & .00000 \\
\hline 240 & 1011986-08-13 03:17:22 & George L. Hunt & 0.89138 & 64.20964 & -171.50262 & Large Boat & Pelagic Survey & Continuous & Centroid & 1986 & 8 & 13 & & 225 & 0.00000 & 0.00000 \\
\hline 241 & 1011986-08-13 03:27:12 & George L. Hunt & 0.89488 & 64.19334 & -171.46064 & Large Boat & Pelagic Survey & Continuous & Centroid & 1986 & 8 & 13 & & 225 & 0.00000 & 0.00000 \\
\hline 242 & 1011986-08-13 03:41:42 & George L. Hunt & 0.89224 & 64.18239 & -171.41916 & Large Boat & Pelagic Survey & Continuous & Centroid & 1986 & 8 & 13 & & 225 & 0.00000 & 0.00000 \\
\hline 243 & 1011986-08-13 03:55:48 & George L. Hunt & 0.89826 & 64.16636 & -171.37960 & Large Boat & Pelagic Survey & Continuous & Centroid & 1986 & 8 & 13 & & 225 & 0.00000 & 0.00000 \\
\hline 244 & 1011986-08-13 04:05:02 & George L. Hunt & 3192 & 4.14492 & 171.34066 & Large Boat & Pelagic Survey & Continuous & Centroid & 1986 & 8 & 13 & & 225 & 0.00000 & 0.00000 \\
\hline 245 & 1011986-08-13 04:14:12 & George L. Hunt & 219 & .12356 & -171.30186 & Large Boat & Pelagic Survey & Continuous & Cent & 1986 & 8 & 13 & & 22 & 0.00000 & 00000 \\
\hline 246 & 1011986-08-13 04:23:22 & . Hunt & 5 & 20 & -1 & Boat & ey & us & $\mathrm{Ce}$ & 1986 & 8 & 13 & & 225 & 0.00000 & .00000 \\
\hline 247 & 1011986-08-13 04:32:32 & George L. Hunt & 3735 & 64.08067 & 22453 & Large Boat & Pelagic Survey & Continuous & Centroid & 1986 & 8 & 13 & & 225 & 0.00000 & 0.00000 \\
\hline 248 & 1011986-08-13 04:42:42 & George L. Hunt & 9735 & 64.05909 & -171.18743 & Large Boat & Pelagic Survey & Continuous & Centroid & 1986 & 8 & 13 & & 225 & 0.00000 & 0.00000 \\
\hline & 1011986-08-13 04:54:52 & George L. Hunt & 9590 & 64.03889 & -171.14711 & Large Boat & elagic Survey & Continuous & Centroid & 1986 & 8 & 13 & & 225 & 0.00000 & 00000 \\
\hline 250 & 1011986-08-13 05:04:06 & George L. Hunt & 0.89947 & 64.01999 & -171.10269 & Large Boat & Pelagic Survey & Continuous & Centroid & 1986 & 8 & 13 & & 225 & 0.00000 & 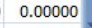 \\
\hline & & & & & & & & & & & & & & & & \\
\hline
\end{tabular}

Figure E8. Cross-tabulation density output from the NPPSD v2.0 Query Form. Note that the field names are limited to meet the restrictions of the $\mathrm{dbf}$ format (10 characters).

The dbf format, in addition to compatible with various database and spreadsheet software can be read directly into ArcGIS (tested on versions $\geq 9.3$ ). To add a dbf file to an ArcGIS project, select "Add Data" from the file menu or standard tool bar. Navigate to the location of the dbf file and select "Add". Once added the file will be displayed in the "Table of Contents" on the left side of the display (fig. E9). Highlight the table and select "Display XY Data" (fig. E9). Users need to identify Longitude as the "X Field" and Latitude as the "Y Field" (fig. E10). Beneath the X-Y fields the coordinate description in a 
new project should say "Unknown Coordinate System." Regardless of what it says, select "Edit" and a new window will open. Navigate to "Geographic Coordinate Systems", then World" and then select "WGS 1984", then select "OK" and the window will close. ArcGIS will then warn you that the table does not have an ObjectID field so functionality may be limited, including selecting querying, or editing features. The table will need to be converted to a shape file or geodatabase file to implement the full functionality of ArcGIS. Right click on your new layer in the Table of Contents, click Data -> Export Data. Confirm that "this layer's source data" is selected for the coordinate system and change the output feature class directory and file name as appropriate. You will be back in the coordinate system window, select " $\mathrm{OK}$ and it will close and the data in the dbf file should display. Note that users will need to change symbology from single symbol if the file contains multiple species or if the user wants to use graduated symbols based on the number or density.

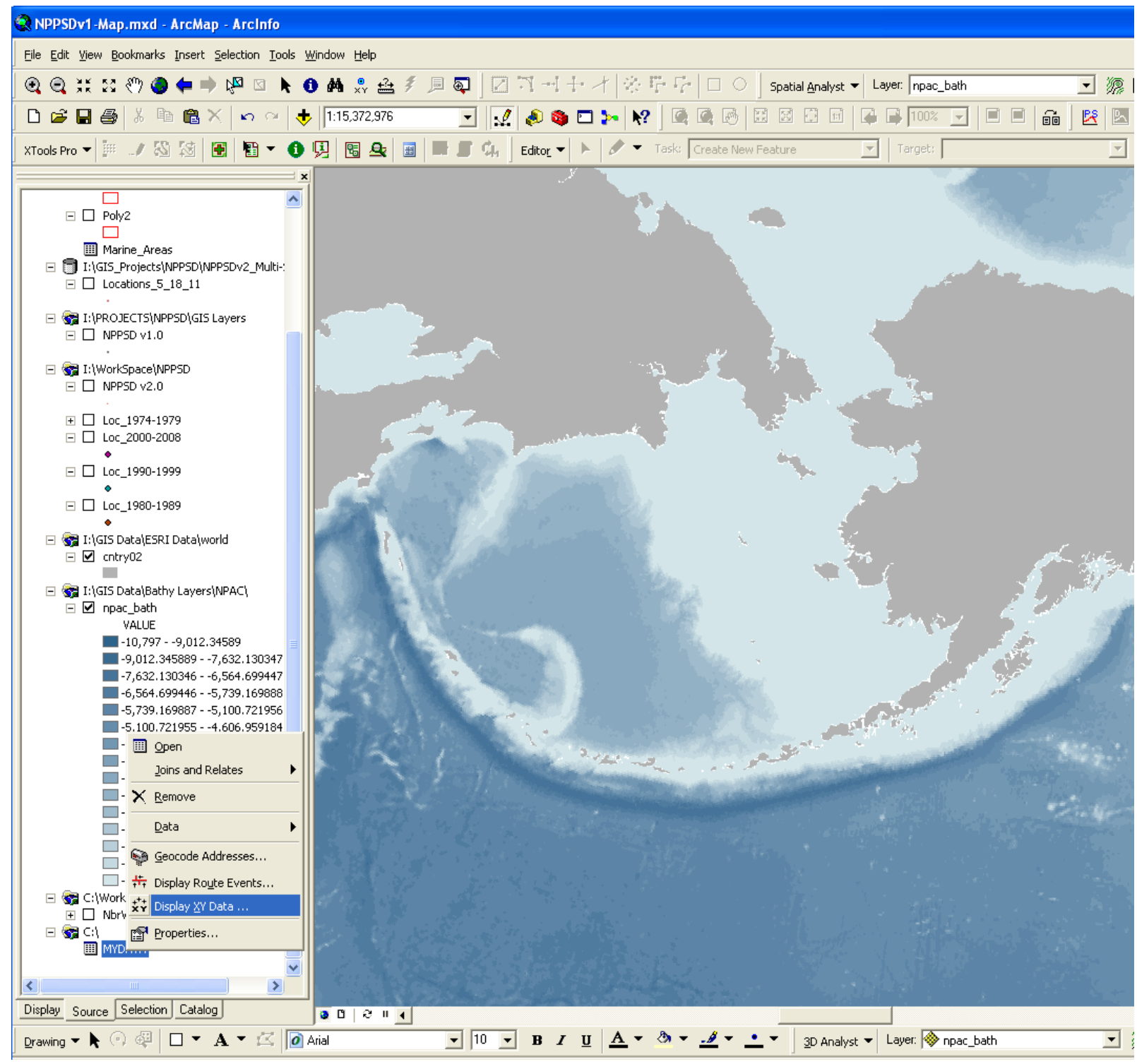

Figure E9. Cross-tabulation density output from the NPPSD v2.0 Query Form. Note that the field names are limited to meet the restrictions of the $\mathrm{dbf}$ format (10 characters). 


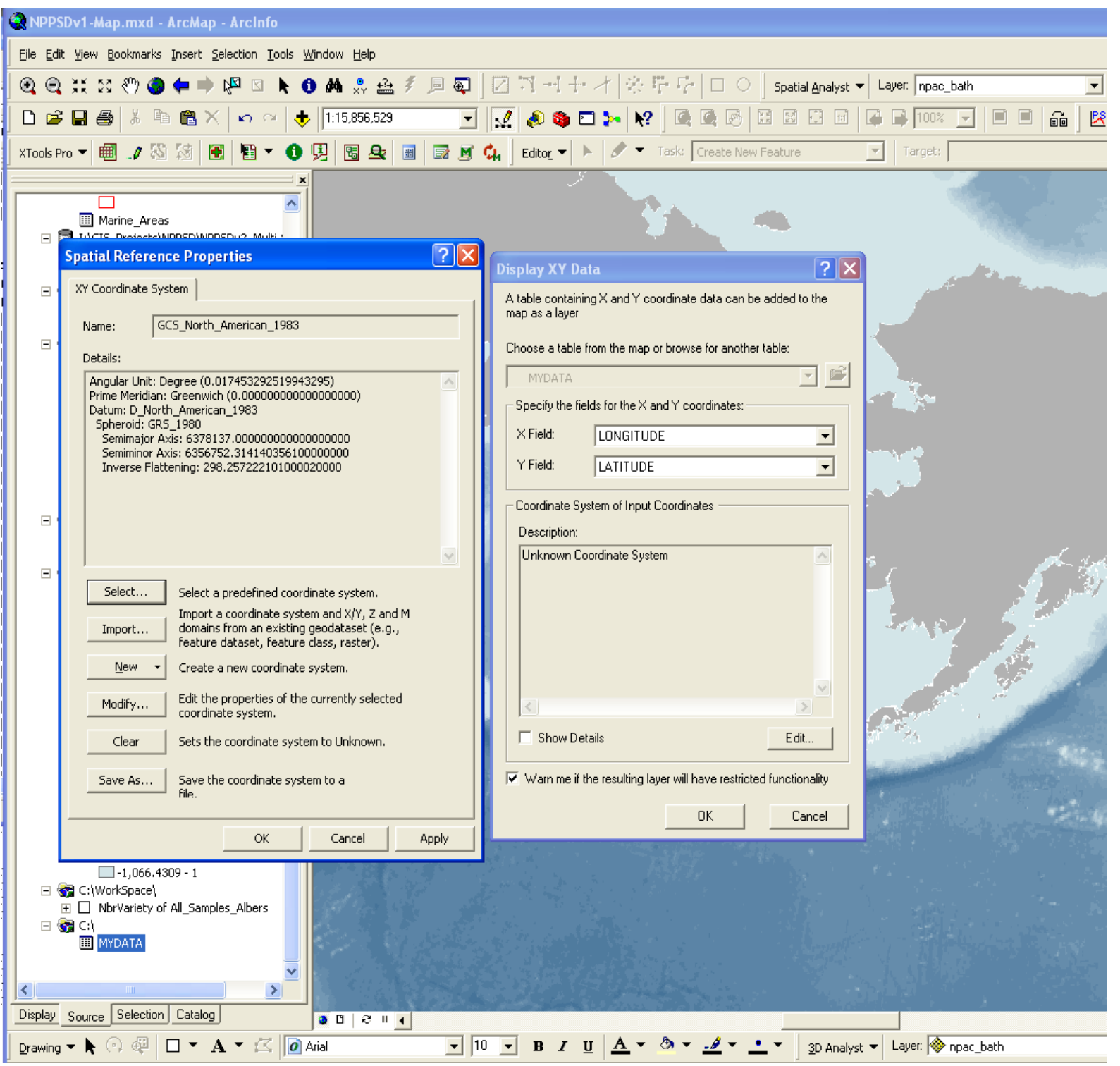

Figure E10. Cross-tabulation density output from the NPPSD v2.0 Query Form. Note that the field names are limited to meet the restrictions of the dbf format (10 characters). 
Publishing support provided by the U.S. Geological Survey Publishing Network, Tacoma Publishing Service Center

For more information concerning the research in this report, contact the Director, Alaska Science Center

U.S. Geological Survey

4210 University $\mathrm{Dr}$

Anchorage, Alaska 99508-4560

http://alaska.usgs.gov 
辛

울

동

올

迟

흘

당

훙 